The Free Internet Journal

for Organic Chemistry
Review

Arkivoc 2020, part vii, 257-305

\title{
Synthetic strategies in curcumin chemistry focused on anticancer applications
}

\author{
Atiruj Theppawong, ${ }^{\text {a,b }}$ Gurkirat Kaur, ${ }^{a}$ Vipan Kumar, ${ }^{c}$ John Van Camp, ${ }^{b}$ and Matthias D’hooghe ${ }^{a, *}$ \\ ${ }^{a}$ SynBioC Research Group, Department of Green Chemistry and Technology, Faculty of Bioscience Engineering, \\ Ghent University, Coupure Links 653, B-9000 Ghent, Belgium \\ ${ }^{b}$ Department of Food Technology, Safety and Health, Faculty of Bioscience Engineering, Ghent University, \\ Coupure Links 653, B-9000 Ghent, Belgium \\ ${ }^{c}$ Department of Chemistry, Guru Nanak Dev University, Amritsar-143005, India \\ Email: matthias.dhooghe@UGent.be
}

Dedicated to Professor Jan Bergman on the occasion of his 80th birthday

Received 07-27-2020

Accepted 11-30-2020

Published on line $12-18-2020$

\section{Abstract}

In spite of having received considerable interest as a potential anticancer agent over the past two decades, curcumin has not been developed into a sturdy drug candidate yet, mainly due to the challenges imposed by its rapidly metabolizable structure, leading to bioavailability and stability issues, and its aspecific activity. To circumvent these obstacles, chemical modification of the parent scaffold has been shown to involve an eligible approach for the construction of curcuminoids with improved properties. This review article provides a compilation of curcumin modifications and the effect thereof on the anticancer activity displayed by the resulting new analogs.

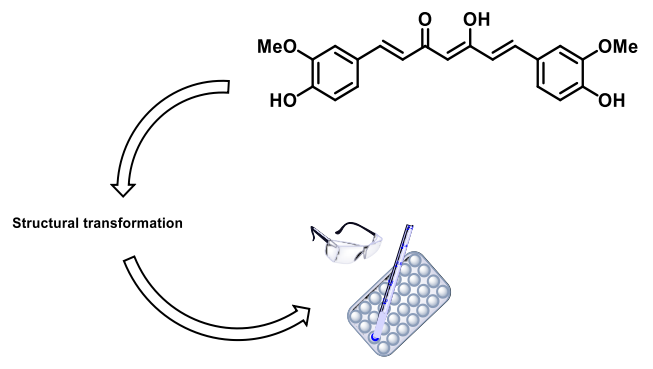

Keywords: Curcumin, Curcuminoids, Bioavailability, Cancer 


\section{Table of Contents}

1. Introduction

2. Chemical Structure and Biological Interest of Curcuminoids

3. General Synthetic Routes to Curcumin and its Analogs

4. Curcumin against Cancer

5. Structural Modification

5.1. Changes in aromatic ring substitutions

5.2. Changes in $\beta$-diketone moiety

5.2.1 Pyrazole and isoxazole analogs

5.2.2 $\beta$-enaminones

5.2.3 Monocarbonyl analogs of curcumin (MACs)

5.3. Modification of both the aromatic rings and the $\beta$-diketone moiety

6. Conclusions

\section{Introduction}

Curcumin, a natural product extracted from the rhizomes of the turmeric plant Curcuma longa, has been commonly used as a food additive and a traditional medicine in South Asia. In addition, curcumin has been explored pharmacologically by many researchers, driven by the shedload of biological potential associated with this compound. The promising prospects of curcumin-based molecules have indeed attracted notable attention, especially in the field of oncology. However, curcuminoids exhibit propitious effects on inflammation, ageing, diabetes, and cardiovascular diseases, among other potential applications as well. ${ }^{1-3}$ Despite this broad therapeutic window, most of the curcumin research is linked to anticancer activity. Malignant disorders represent a major health challenge accounting for more than 8 million deaths per year and therefore new therapeutic opportunities in that context are highly desirable. Curcumin-based studies within that framework include curcumin-mediated suppression of cell proliferation, reduction of tumor load and induction of apoptosis in various cancers, both in vitro and in vivo. ${ }^{4}$ The anticancer activity of curcumin is effective through several pathways such as an induction of p53-dependent apoptosis pathways in different cancer cells (colon, breast, bladder), and stimulation of both p53-dependent and p53-independent G2/M phase arrest has also been shown to exert inhibitory effects on cyclooxygenase COX-2 and proto-oncogene cyclin D1, mediated through the transcription factor NF-kB and hence the restriction of tumor cell growth in colorectal cancer. ${ }^{5-8}$ The growth of malignant tumors has been observed to be restricted upon these mechanisms along with an inclusion of pro-apoptotic, antiproliferative, antioxidant and anti-inflammatory mechanisms. ${ }^{9,10}$ However, the lack of understanding of the mode of action coupled with other issues such as a low bioavailability leading to a poor absorption in the body still remains a huge obstacle in the development of curcumin-derived pharmaceuticals. Indeed, although curcumin has been amply shown to inhibit cancer cell proliferation, it is rapidly metabolized and systemically eliminated from the human body, and it suffers from chemical degradation in aqueous solutions. ${ }^{11,12}$ In contrast to other polyphenols, the degradation of curcumin is not related to its phenolic groups but is rather induced by hydrolysis of the labile B-diketo moiety. Unfortunately, these drawbacks imply a serious concern and hamper potential applications of curcumin in health care. In addition to bioavailability and stability issues, the mode of action of curcuminoids remains poorly understood; hence, they are often considered to be pan-assay interference compounds (PAINS) 
showing rather unspecific activity across a range of assays. ${ }^{13}$ But it has been recently demonstrated that curcumin is able to block Kaposi's sarcoma associated herpesvirus replication and inhibits the pathogenic processes of cell invasion and angiogenesis predicting a potential application in treatment of viral infection and virus-related cancer and also suggesting that curcumin is not a PAINS but an inhibitor to APE1 redox function that affects many genes and pathways. ${ }^{14}$ Nevertheless, it might be possible to circumvent problems associated with low bioavailability, low stability and non-specific activity to a great extent through structural modifications of the basic curcumin framework. Curcumin contains a $\beta$-diketo moiety, two phenolic groups and two olefinic entities delivering a broad diversity of options for chemical modification of the curcumin scaffold. The curcumin framework has been utilized frequently for a variety of straightforward transformations, mainly focused on the synthesis of pyrazoles and isoxazoles, ${ }^{15-17}$ but the dearth of the investigation of an extensive range of transformations still provides opportunities for further exploration. For example, a recent study revealed improved water solubility, antioxidant effects and anti-proliferative activities upon replacement of the curcumin $\beta$-diketo moiety with a $\beta$-enaminone group. ${ }^{18,19}$ In addition to enaminone production, other synthetic transformations, such as replacement of the aromatic benzene rings by heteroaromatic scaffolds and simultaneous modification of the olefinic and diketo moieties, were also addressed as a part of this review to examine rather unapprised innovative classes of curcuminoids.

Despite many recent realizations in curcuminoid chemistry and biology, current contributions remain insufficient for the development of curcumin-based drugs, which has been acknowledged in a J. Med. Chem. Perspective, calling upon the curcumin chemistry community to move towards more out-of-the-box approaches. ${ }^{20}$ The present review article has the intention to outline the state-of-the-art and to provide anchor points to guide future synthetic endeavors in this field of research.

\section{Chemical Structure and Biological Interest of Curcuminoids}

Curcumin (diferuloylmethane) is a polyphenolic compound that can be isolated from different sources, e.g., the roots of the plants Curcuma longa, Curcuma zedoaria, and Curcuma aromati. The major curcuminoids present in turmeric are bisdemethoxycurcumin 2, demethoxycurcumin $\mathbf{3}$ and the later identified cyclocurcumin $4 .^{21}$ The main components of commercially available curcumin samples are approximately $77 \%$ curcumin 1, 17\% demethoxycurcumin (DMC), and 3\% bisdemethoxycurcumin (BDMC) (Figure 1)..$^{22,23}$ Curcuminoids are a class of natural compounds found in turmeric responsible for imparting a yellow color to it, but are not essentially limited to diferuloylmethane (curcumin), demethoxycurcumin and bisdemethoxycurcumin. Turmeric has initially been put forward as a food spice used as an essential ingredient of curries and as a part of Asian cuisine, primarily for the flavor and the color, and has also been used to cure a variety of inflammation-related health problems by Asians since long. ${ }^{24,25}$ The scope of the research to seek new potential anticancer agents stems from the toxicity, virtually inefficiency, and expense of the existing ones, thus rendering them far out of reach for a large number of population groups. Curcumin has been shown to have a potentially strong therapeutic profile against a variety of cancers and a promising ability to suppress transformation, proliferation, and metastasis of tumors based on research in the past few decades with no considerably muddling side effects often associated with traditional medications like nausea, vomiting, diarrhea or even liver failure. ${ }^{22,26,27}$ Curcumin has also been noted for its rather high tolerance levels with doses of 12 grams per day being both safe and efficacious. ${ }^{28}$ To that end, its use as a regular dietary supplement in some parts of Asia might therefore be one of the contributing factors for the lower incidence of cancer in those regions compared to the western world. ${ }^{29}$ 

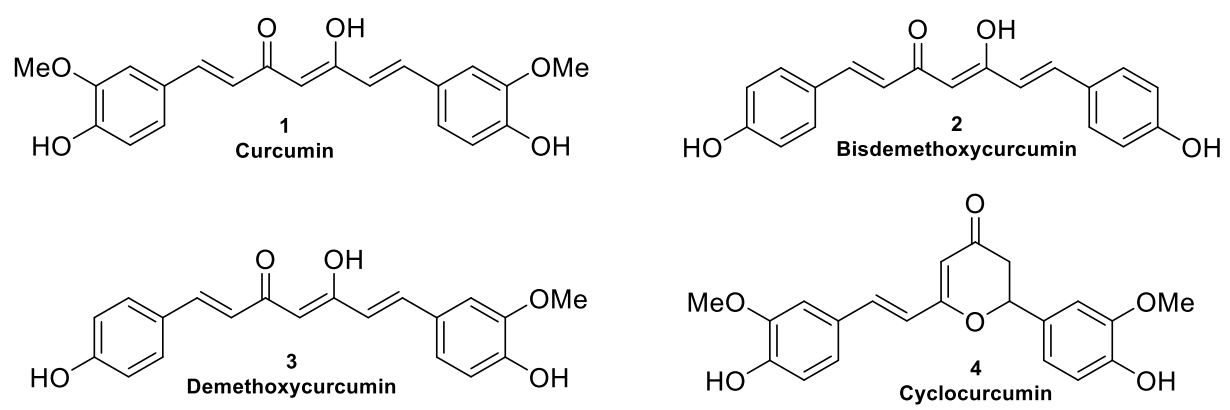

Figure 1. Chemical structure of curcuminoids 1-4.

Chemically speaking, curcumin is a bis- $\alpha, \beta$-unsaturated $\beta$-diketone that exhibits keto-enol tautomerism, with the enol tautomer as the predominant form in solution based on NMR studies at $\mathrm{pH} 3-9 .{ }^{30}$ The planarity of the enol form allows for intramolecular hydrogen bonding (which leads to a more stable structure). However, the compound is more stable in acidic conditions and rapidly degrades at either natural or alkaline $\mathrm{pH}$ (Figure 2). ${ }^{11,20,31}$ There have been attempts to improve the stability of $\mathbf{1}$ through synthetic manipulations, including encapsulation strategies, ${ }^{32,33}$ removal or protection of oxidation sites, ${ }^{34}$ and derivatization of the diketone moiety. $^{35,36}$

An example of the effect of structural modifications of the curcumin scaffold comprises of the significantly different antioxidant, antitumor, and anti-inflammatory activities of compounds 1-3 through only the introduction of a methoxy substituent. Till date, there has been no clear correlation between the physicochemical and molecular properties of the three curcuminoids and their biological activities, but there are reports that provide clues to map the groups responsible for a given biological activity within the curcuminoid series. Most studies suggest that curcumin $\mathbf{1}$ is the best radical scavenger and antioxidant among the three, followed by compounds $\mathbf{3}$ and $\mathbf{2}$ in decreasing order of potential, which is explicable in terms of $O$ methoxy substitutions: intramolecular hydrogen bonding between the phenolic hydroxy and methoxy groups (in $\mathbf{1}$ and $\mathbf{3}$ ) influences the $\mathrm{O}-\mathrm{H}$ bond energy, subsequently easing the $\mathrm{H}$-atom abstraction by free radicals, and thus the absence of this methoxy group in the compound $\mathbf{2}$ renders it as the weakest radical scavenger. ${ }^{37}$

Despite great advances in curcuminoid research, there are still several challenges to be addressed, such as understanding the mode of action of curcumin and improving its low bioavailability due to its poor solubility and fast metabolism. Curcumin has also been observed (via HPLC-MS) to degrade into vanillin, ferulic acid, and feruloylmethane under different conditions. ${ }^{11,38}$ Thus, for the foreseeable future, further research shall most likely focus on overcoming these disadvantages through encapsulations/nanoparticles, ${ }^{39-62}$ combination effects with piperine to enhance the bioactivity/bioavailability ${ }^{63-73}$ and - of particular interest to this overview - structural modifications. $7,22,23,74,75$

In this literature review, the general synthetic route towards curcumin and optimization thereof is discussed, since that approach forms the basis for further derivatization. An overview of the oncological applications of curcumin(oids) has been dispensed, followed by a discussion of the structural modifications to the curcumin scaffold that have been performed as a strategy to improve its pharmacokinetic profile. 

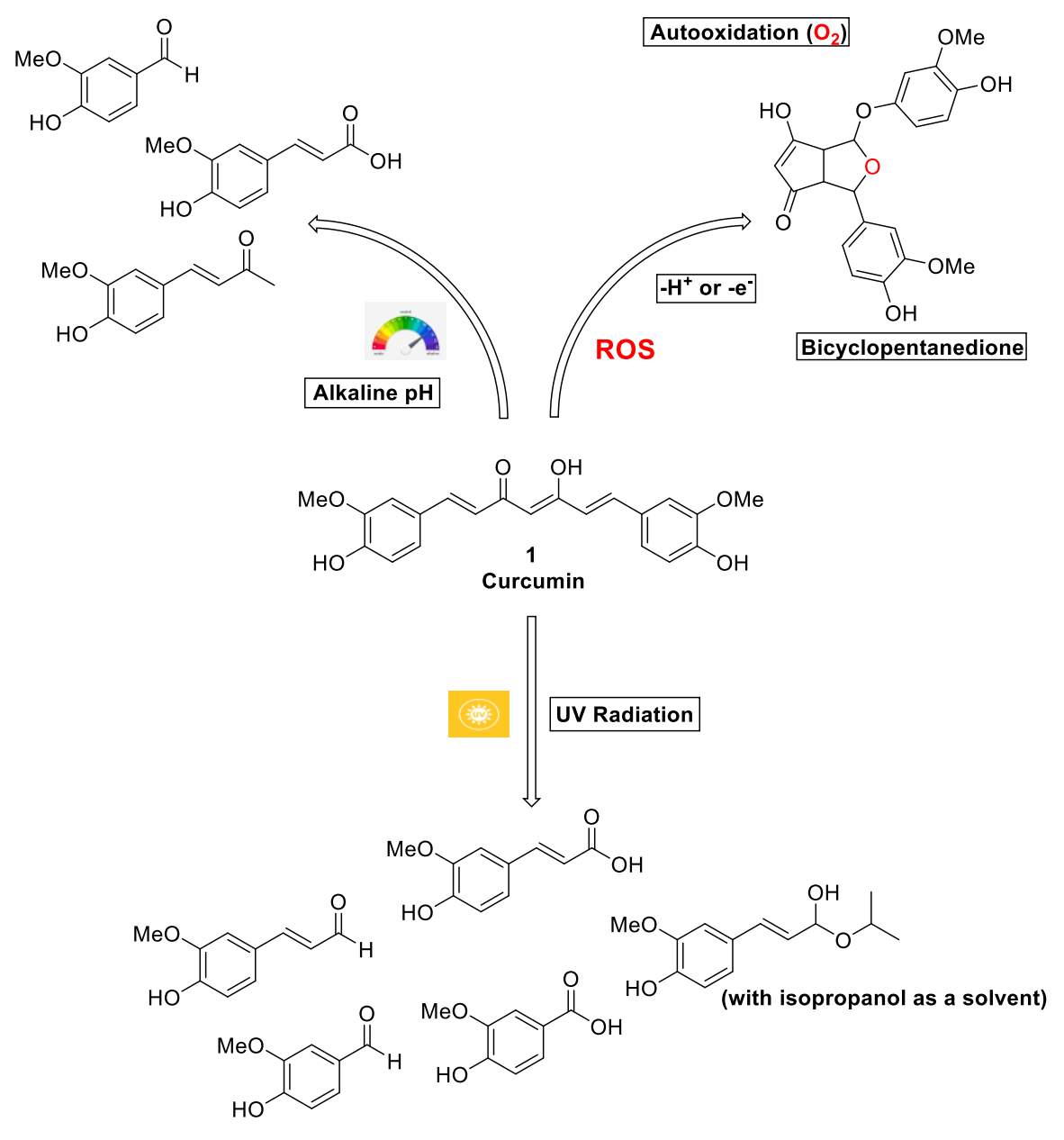

Figure 2. Possible major degradation pathways of curcumin 1.

\section{General Synthetic Routes to Curcumin and its Analogs}

The general synthetic strategy towards curcumin and its derivatives involves the condensation of substituted benzaldehydes with acetylacetone (Figure 3). ${ }^{76,77}$ The synthesis of curcumin 1 under variable reaction conditions such as solvent systems, complexing agents, temperature, time and amount of $\mathrm{H}_{2} \mathrm{O}$ scavenger, has been studied in detail in order to achieve an optimized process. For the synthesis of curcumin 1 , acetylacetone and 4-hydroxy-3-methoxybenzaldehyde (vanillin) were used in a theoretically stoichiometric ratio (1:2). Boric oxide was used as a complexing agent to protect the C3 of acetylacetone from Knoevenagel condensation. Solvent selection was also an important factor in the optimization process to obtain the appropriate solubility for the reactants, intermediates and products. Various solvents were screened, including dimethylformamide (DMF), ethyl acetate (EtOAc), 1,4-dioxane, acetonitrile (MeCN) and toluene (Table 1). Furthermore, it is critical to select a basic catalyst that ideally only deprotonates the methyl groups of acetylacetone (in all chosen solvents), because a stronger base can also deprotonate the phenolic $\mathrm{OH}$ group, which might result in the deactivation of vanillin and thus prevent the condensation reaction. The base $n$-butylamine $\left.(n \text {-BuNH})_{2}\right)$ was identified as the most appropriate catalyst. Catalyst loading was performed slowly up to $40 \%$ (volume) of acetylacetone. $^{76,78}$

The reaction was carried out under anhydrous conditions by using high purity solvents, as water molecules could bind to the diketone complex (i.e., complex of acetylacetone and boron, Figure 3) and reduce the yield. 
However, water is also produced when the diketone complex and curcumin are formed. Therefore, tributyl borate $(n-\mathrm{BuO})_{3} \mathrm{~B}$ was incorporated as a water scavenger in order to bind to $\mathrm{H}_{2} \mathrm{O}$ molecules produced during the reaction. Varying ratios of $(n-\mathrm{BuO})_{3} \mathrm{~B}$ were tested to find the optimal amount. ${ }^{76-78}$ Another parameter influencing the reaction between the diketone complex and vanillin is the temperature. Below $40^{\circ} \mathrm{C}$, the reaction rate was too slow to get a workable yield, so higher temperature conditions had to be procured. In that respect, the reaction conditions were altered by varying the solvents at different temperatures (Table 1), with $n$-butylamine as a catalyst and $(n-\mathrm{BuO})_{3} \mathrm{~B}$ as a water scavenger (if any). First the reaction between acetylacetone and vanillin with a molar ratio of $1: 2$, respectively, was carried out at $60^{\circ} \mathrm{C}$ in $\mathrm{DMF}$. The complexing agent $\left(\mathrm{B}_{2} \mathrm{O}_{3}\right)$ was added at an equivalent molar ratio to acetylacetone without any water scavenger. After $12 \mathrm{~h}$, only a $6 \%$ yield was obtained. No significant improvement in yield was observed upon repetition with a water scavenger. ${ }^{78}$

Subsequently, other solvents were utilized with varying reaction parameters, including amount of water scavenger $(n-\mathrm{BuO})_{3} \mathrm{~B}$ and catalyst $\left(n-\mathrm{BuNH}_{2}\right.$ or other bases), time and temperature. In ethyl acetate, an increased amount of $(n-\mathrm{BuO})_{3} \mathrm{~B}$ did improve the yield significantly from $21 \%$ to $43 \%$. In the presence of acetonitrile and dioxane, almost identical yields were obtained. Using toluene as a solvent resulted in very low yields, even at higher temperatures. Ethyl acetate (EtOAc) was found to give the most significant improvement in yield due to better solubility of the reactants, intermediates and products, delivering the highest yield (89\%) at $80^{\circ} \mathrm{C}$ (Table 1 , bold) with a 2:1 ratio of $(n-\mathrm{BuO})_{3} \mathrm{~B}$ and $\mathrm{B}_{2} \mathrm{O}_{3}$ to acetylacetone-vanillin solution. ${ }^{76}$

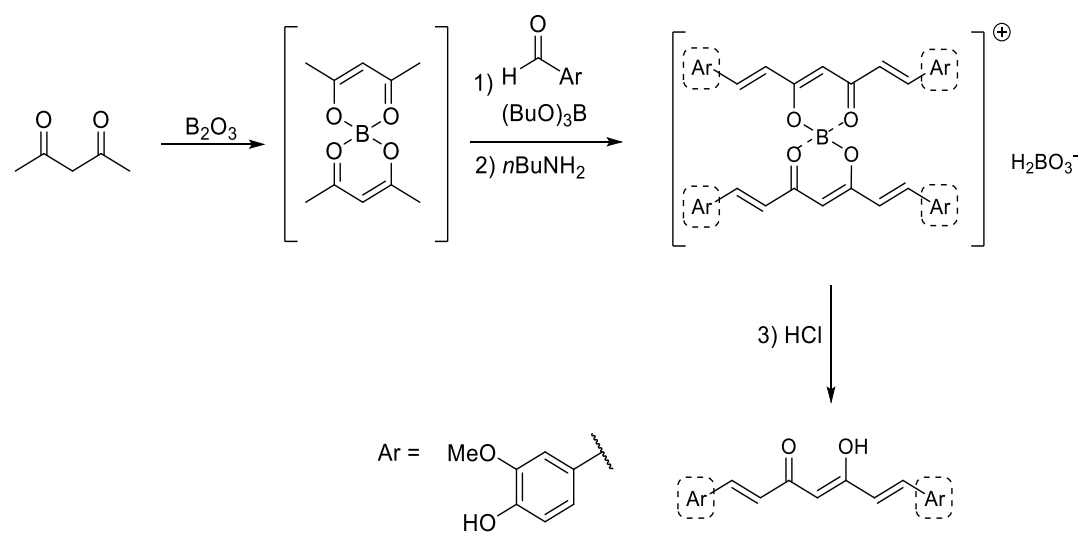

Figure 3. General synthetic route to curcumin 1.

Table 1. Parameter variation for curcumin synthesis ${ }^{76,78}$

\begin{tabular}{lccccc}
\hline \multicolumn{1}{c}{ Solvent } & $\begin{array}{c}\mathrm{H}_{2} \mathrm{O} \\
\text { scavenger }\end{array}$ & $\begin{array}{c}\text { Ratio } \\
(n \mathrm{BuO})_{3} \mathrm{~B}: \mathrm{B}_{2} \mathrm{O}_{3}\end{array}$ & Temp. $\left({ }^{\circ} \mathrm{C}\right)$ & Time $(\mathrm{h})$ & Yield (\%) \\
\hline DMF & - & - & 60 & 12 & 6 \\
DMF & $(n-\mathrm{BuO})_{3} \mathrm{~B}$ & $2: 1$ & 80 & 12 & 15 \\
EtOAc & - & - & 60 & 4 & 21 \\
EtOAC & $(n-\mathrm{BuO})_{3} \mathrm{~B}$ & $2: 1$ & 60 & 4 & 43 \\
EtOAC & $(n-\mathrm{BuO})_{3} \mathrm{~B}$ & $\mathbf{2 : 1}$ & 80 & 4 & 89 \\
Dioxane & $(n-\mathrm{BuO})_{3} \mathrm{~B}$ & $2: 1$ & 60 & 12 & 20 \\
MeCN & $(n-\mathrm{BuO})_{3} \mathrm{~B}$ & $2: 1$ & 60 & 12 & 18 \\
Toluene & $(n-\mathrm{BuO})_{3} \mathrm{~B}$ & $2: 1$ & 60 & 12 & 3 \\
Toluene & $(n-\mathrm{BuO})_{3} \mathrm{~B}$ & $2: 1$ & 80 & 12 & 6 \\
\hline
\end{tabular}




\section{Curcumin against Cancer}

Cancer involves the dysregulation of multiple cellular pathways that normally regulate cell proliferation. The annual global incidence of cancer is expected to increase from 14.1 million new cases in 2012, with 8.2 million deaths to nearly 25 million new cases in $2032 .{ }^{79}$ Most drugs currently available for the treatment of cancer have limited potential because they are either very toxic, highly inefficient, or too expensive for the majority to afford. Treatments without these disadvantages are constantly being sought for, with curcumin presenting itself as a potential scaffold for future studies. To an advantage, curcumin has been consumed as a dietary supplement for centuries and is considered to be pharmacologically safe. ${ }^{25}$

Accumulating evidence suggests that curcumin has a diverse range of molecular targets, which supports the notion that it influences numerous biochemical and molecular cascades. Among its molecular targets are transcription factors, growth factors and their receptors, cytokines, enzymes, and genes regulating cell proliferation and apoptosis. Extensive investigation suggests that curcumin has therapeutic potential in the treatment of various disorders (Scheme 1 ) as it is known to reduce blood cholesterol, ${ }^{80-85}$ prevent low-density lipoprotein oxidation, ${ }^{86-88}$ inhibit platelet aggregation, ${ }^{89,90}$ suppress thrombosis ${ }^{91,92}$ and myocardial infarction, ${ }^{93-96}$ suppress symptoms associated with type II diabetes, ${ }^{97-104}$ rheumatoid arthritis, ${ }^{105-109}$ multiple sclerosis $^{110}$ and Alzheimer's disease, ${ }^{111-115}$ inhibits HIV replication, ${ }^{116-124}$ enhance wound healing, ${ }^{125-130}$ protect against liver injury, ${ }^{131-138}$ prevent cataract formation, ${ }^{139-141}$ protect from pulmonary toxicity and fibrosis, has therapeutic effects in leishmaniasis, ${ }^{142-144}$ and has anti-atherosclerotic activity. ${ }^{145-147}$ Most importantly, there is extensive literature suggesting that curcumin has potential in the prevention and treatment of various cancers, including colorectal cancer, ${ }^{148,149}$ pancreatic cancer, ${ }^{150}$ breast cancer, ${ }^{70,151}$ prostate cancer, ${ }^{152}$ multiple myeloma, ${ }^{151}$ lung cancer and oral cancer. ${ }^{151}$ The ability of curcumin to target multiple pathways makes it an extremely potent anticancer agent. Despite having multiple pharmacological effects and being safe in phase-I clinical evaluations (even at high doses of $12 \mathrm{~g} /$ day), ${ }^{28}$ curcumin has poor in vivo bioavailability, as demonstrated by its low serum levels and limited tissue distribution. ${ }^{12,153-155}$ It has been found that curcumin can be mostly metabolized in liver (hepatocyte cells) and intestine, ${ }^{156}$ through both conjugation and reduction pathways in humans and rodents. Curcumin given orally undergoes conjugation, resulting in curcumin glucuronide and sulfates on hydroxy positions on the curcumin scaffold (Figure 5). Curcumin administered intraperitoneally or systemically undergoes reduction to generate tetrahydrocurcumin (THC, 5), hexahydrocurcumin (HHC, 6) and octahydrocurcumin (OHC, 7) (Figure 4 and Scheme 2). ${ }^{157,158}$ It has been suggested by a study conducted for evaluation of tetrahydrocurcumin $\mathbf{5}$ as an anticancer agent relative to curcumin and a standard anticancer drug 5-fluorouracil (5-FU) employing three ESCC cell lines TE-1, TE-8 and KY-5 that further investigation of tetrahydrocurcumin in combination with standard treatments should be considered particularly for chemo-resistant ESCC because of the observed significant suppression of TE-1 cell proliferation with 5-FU in combination with tetrahydrocurcumin in contrast to no significant repression with 5FU alone at the same dosage. ${ }^{159}$ Tetrahydrocurcumin $\mathbf{5}$ has also been gaining research interest because of a better water solubility, anti-oxidative activity and chemical stability than curcumin. The revelation from many in vitro and in vivo studies that it brings into play regarding anti-cancer effects through diverse mechanisms such as xenobiotic detoxification, metastasis, proliferation, inflammation, oxidative stress and programmed cell death gives an idea that its utility is yet to be extensively evaluated as only a few oral bioavailability and pharmacokinetic studies have been performed so far. ${ }^{160}$

Recently a nanoparticle-based administration of curcumin resulted in a 27-fold increase of blood levels in humans compared to that of curcumin powder indicating a promising therapeutic strategy for tackling bioavailability issues. ${ }^{161}$ Moreover, the comparisons between orally administered and intravenously (IV) 
administered routes have been illustrated in Scheme 2 in order to provide a clear understanding of the different ways of administering curcumin and show its metabolism throughout Phases I and II on gut microbiota/liver.
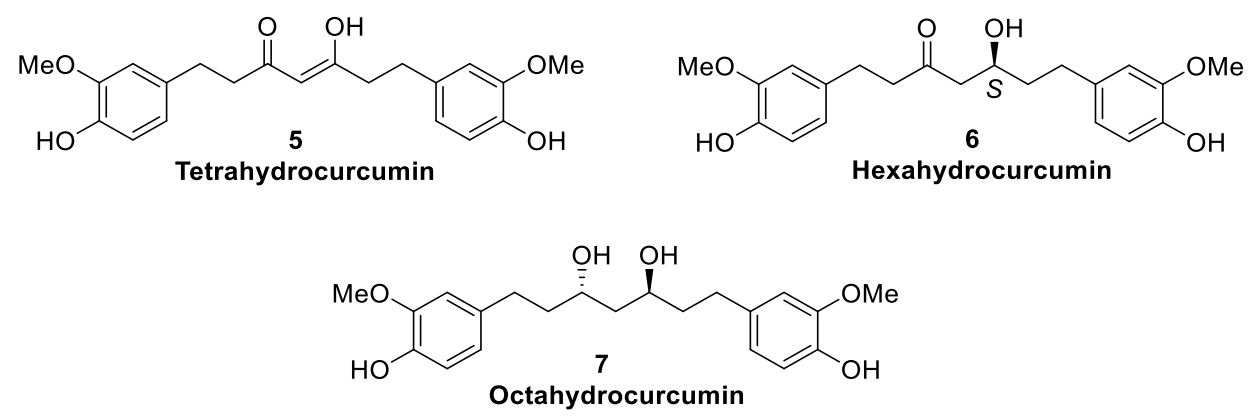

Figure 4. Metabolization of curcumin through reduction pathways provides analogs 5-7.

Although the multicomponent nature of curcumin is well documented, it is not always clear as to which structures exist in a particular preparation. Herein the term curcumin will often be used interchangeably with curcuminoids unless a distinction is specifically made. Many studies with in vitro experiments use synthetic, pure curcumin while most in vivo studies and clinical trials use a mixture of curcuminoids. ${ }^{20}$ In many scientific and medicinal circles, the extensive reported effects of curcumin have marked it as an imminent breakthrough therapy for complex diseases that are thought to require potent but nonselective remedies. Unfortunately, the uncritical enthusiasm for its potential benefits often disregards its dark side (poor bioavailability and fast metabolism). ${ }^{162}$ This eagerness could lead to an overly-optimistic interpretation of results, and consequently, compounds could be misidentified as a hit for drug development. As a matter of fact, neither curcumin nor its known analogs appear to possess the properties required for good drug candidates, i.e., chemical stability, high water solubility, potency, selectivity, high bioavailability, broad tissue distribution and stable metabolism. In that respect, the key challenge in curcumin research involves the elimination of these undesirable properties through structural modification and careful biological evaluation of novel types of curcuminoids, hopefully obtaining good candidates for an anticancer drug in the process. 


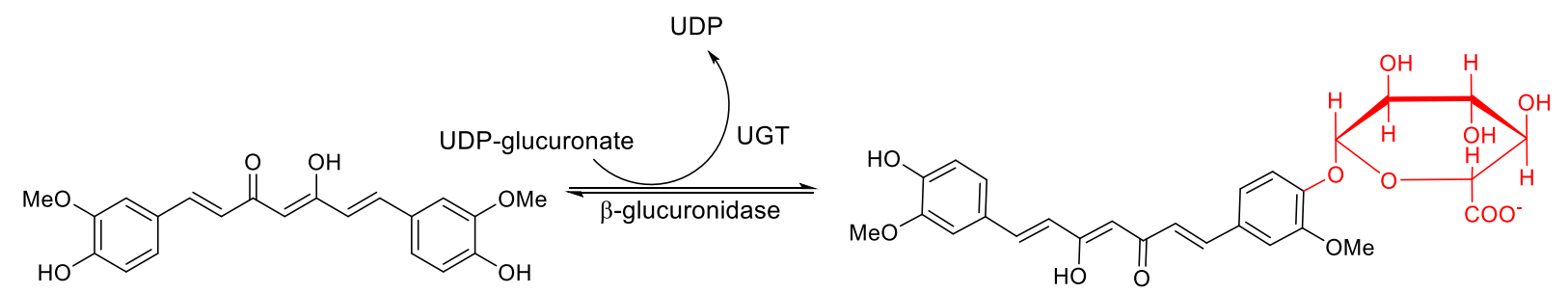

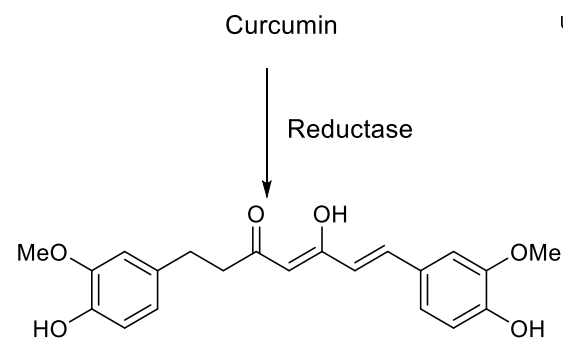

Dihydrocurcumin<smiles>COc1cc(CCC(=O)C=C(O)CCc2ccc(O)c(OC)c2)ccc1O</smiles><smiles>COc1cc(CCC(=O)CC(O)CCc2ccc(O)c(OC)c2)ccc1O</smiles>
Hexahydrocurcumin<smiles>COc1cc(CCC(O)CC(O)CCc2ccc(O)c(OC)c2)ccc1O</smiles>

UGT: UDP-glucuronosyl transferase
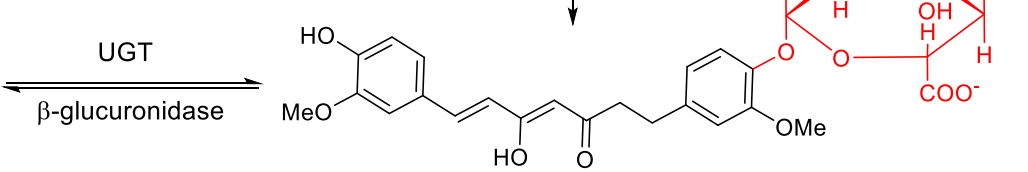

Dihydrocurcumin-glucuronide

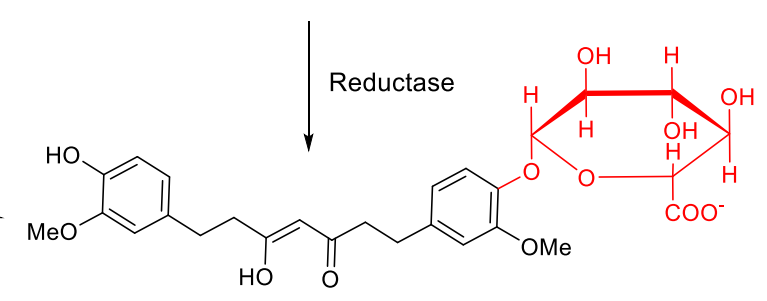

Tetrahydrocurcumin-glucuronide

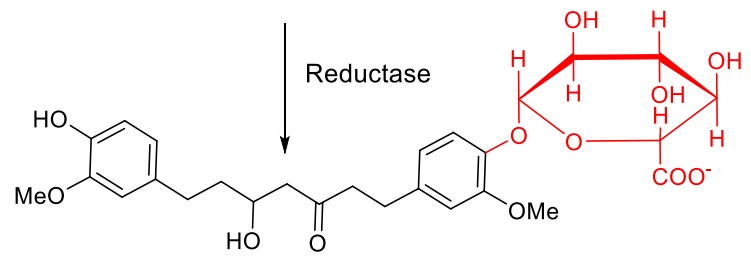

Hexahydrocurcumin-glucuronide

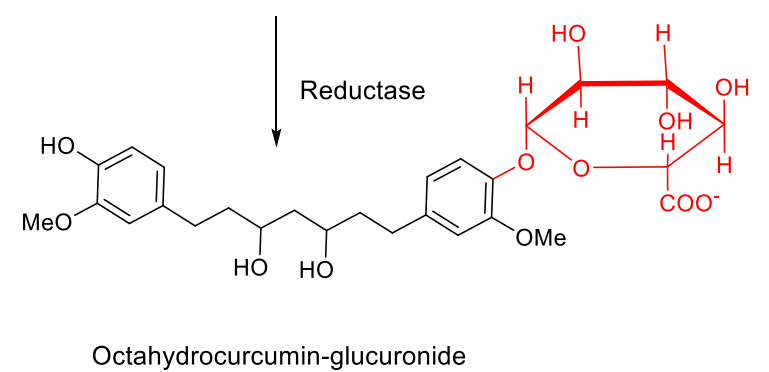

Figure 5. Phase I and phase II (glucuronidation) metabolism of curcumin via UGT enzyme. ${ }^{163,164}$ 
Infectious diseases

- Malaria

- HIV

- Bacterial i

- - Fungal - -infection

\section{Lifestyle-related diseases}

- Myocardial infarction

- Heart failure

- Atherosclerosis

- Diabetes mellitus

- Alcoholism

- Liver dysfunction

- Kidney disease
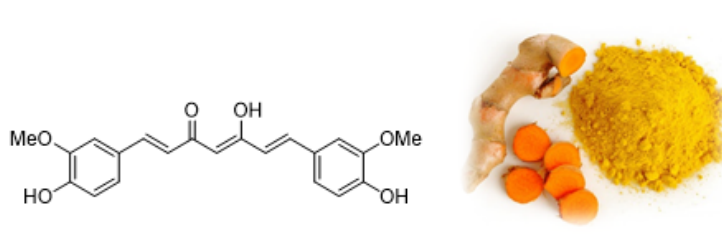

- Breast cancer

- Gastro intestinal cancers

$\begin{array}{ll}- & \text { Esophageal } \\ - & \text { Gastric } \\ \text { - Intestinal } \\ \text { - Colorectal } \\ \text { - Hepatic } \\ \text { - Pancreatic }\end{array}$

- Skin cancer

- Oral cancer

- Bone cancer

- Reproductive system cancers

- Gastric ulcer

- Pancreatitis

- Ulcerative colitis

- Inflammatory bowel disease

- Allergy
Neurological diseases

- Alzheimer's

- Parkinson's

- Epilepsy

\section{Other}

- Depression

- Muscular fatigue

- Osteoporosis

- Psoriasis
- Cervical

- Ovarian

- Urological cancers

- Bladder

- Kidney

- Prostate

- Hematological cancers

- Pulmonary cancer

- Thymic cancer

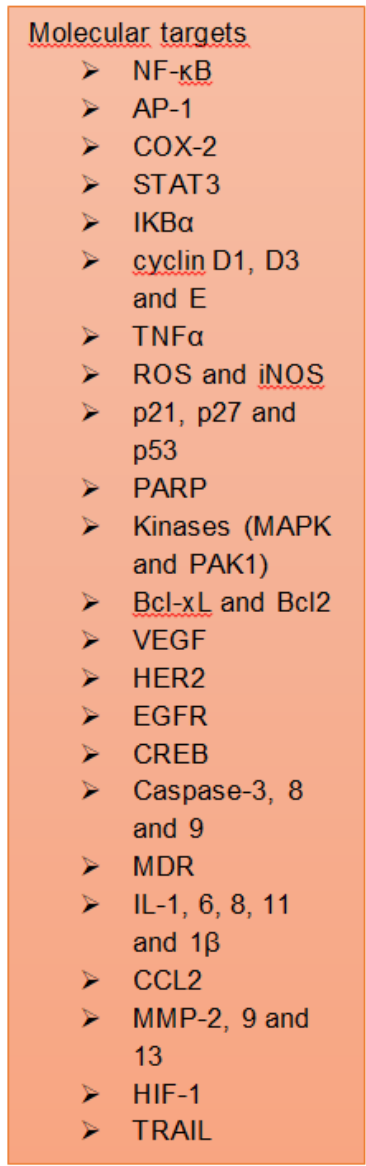

Scheme 1. General illustration of the biological effects of curcumin. 


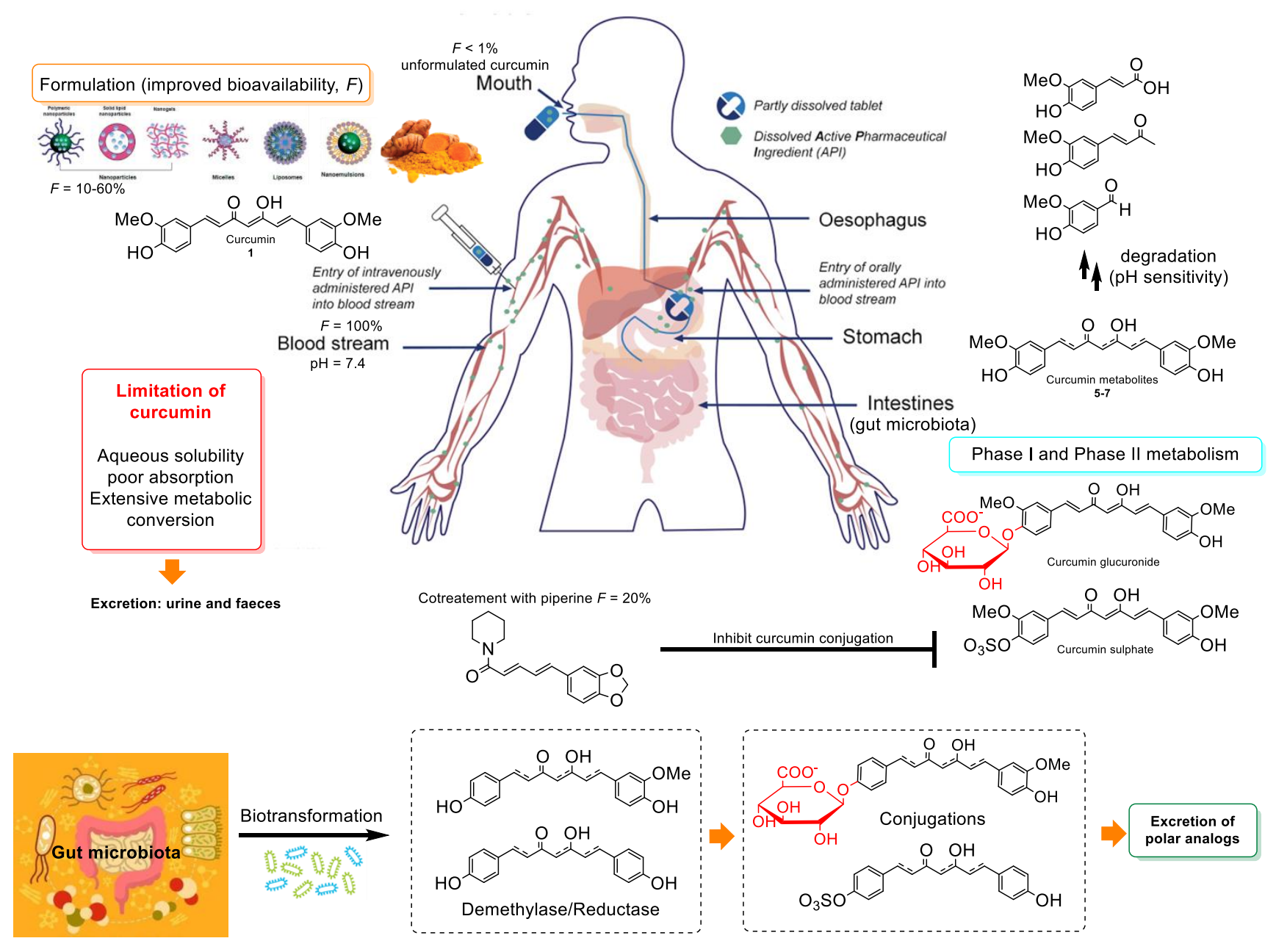

Scheme 2. An illustration of potential delivery systems (oral administration vs IV routes) ${ }^{156}$ to enhance curcumin bioavailability $(F)$ via either formulations ${ }^{41,43,59,61,62}$ or piperine ${ }^{66,69,71}$ and metabolic conversion/detoxification (Phase I and II metabolism) in either intestine (gut microbiota) ${ }^{165-170}$ or liver. $^{156,}$ 171,172,173

\section{Structural Modification}

The rapid degradation of curcumin brings about many challenges while investigating its biological influences (both in vitro and in vivo), which could be overcome through chemical modification strategies. Curcumin is a symmetrical diferuloylmethane, consisting of a methoxy group and a hydroxy group on its aromatic rings, a heptadiene with two Michael acceptors, and a $\beta$-diketone moiety. These groups are often modified in the hope of creating structural homologs with improved bioactivity and/or bioavailability compared to the original structure. Generally, an aldehyde (usually vanillin) and acetylacetone form the building blocks of curcumin. A wide variety of curcumin analogs can be synthesized by using different aldehydes as well as acetylacetone derivatives, ${ }^{119,174-192}$ including C3-substituted acetylacetone or acetylcycloalkanones (Figure 6). ${ }^{193,194}$

A structure-activity relationship (SAR) study of symmetrical curcuminoids showed that the feruloyl (aromatic) moiety plays a critical role in various biological functions. As previously mentioned, curcumin is stable at an acidic $\mathrm{pH}$, and its instability at a $\mathrm{pH}$ above 6.5 (i.e. physiological conditions) is most likely due to the active methylene group and the $\beta$-diketone moiety. This suggests that the deletion or modification of the $\beta$-diketone 
moiety may contribute to the enhancement of stability of curcuminoids. In this literature study, we focus on several curcumin analogs prepared both synthetically and semi-synthetically, mostly containing changes in aromatic ring substitutions or transformations of the $\beta$-diketone moiety (Scheme 3 ).

The synthesis and anti-tumor assessment of the series of phosphorylated, etherified and esterified forms of curcumin against human breast cancer MCF-7, hepatocellular carcinoma Hep-G2 and cervical carcinoma HeLa cells showed a better antitumor cell line growth activities against HeLa cells in comparison with those of curcumin itself. ${ }^{195}$ Another simple prodrug report has been put on the table which takes into account the generation of nanoparticles of curcumin in situ allowing it to perform as an anticancer and anti-inflammatory agent reproducibly; diphosphorylated curcumin which in this approach essentially is a precursor for curcumin and a substrate of alkaline phosphatase (ALP) exhibited selective inhibition of cancer cells that overexpressed ALP without affecting normal cells. ${ }^{196}$

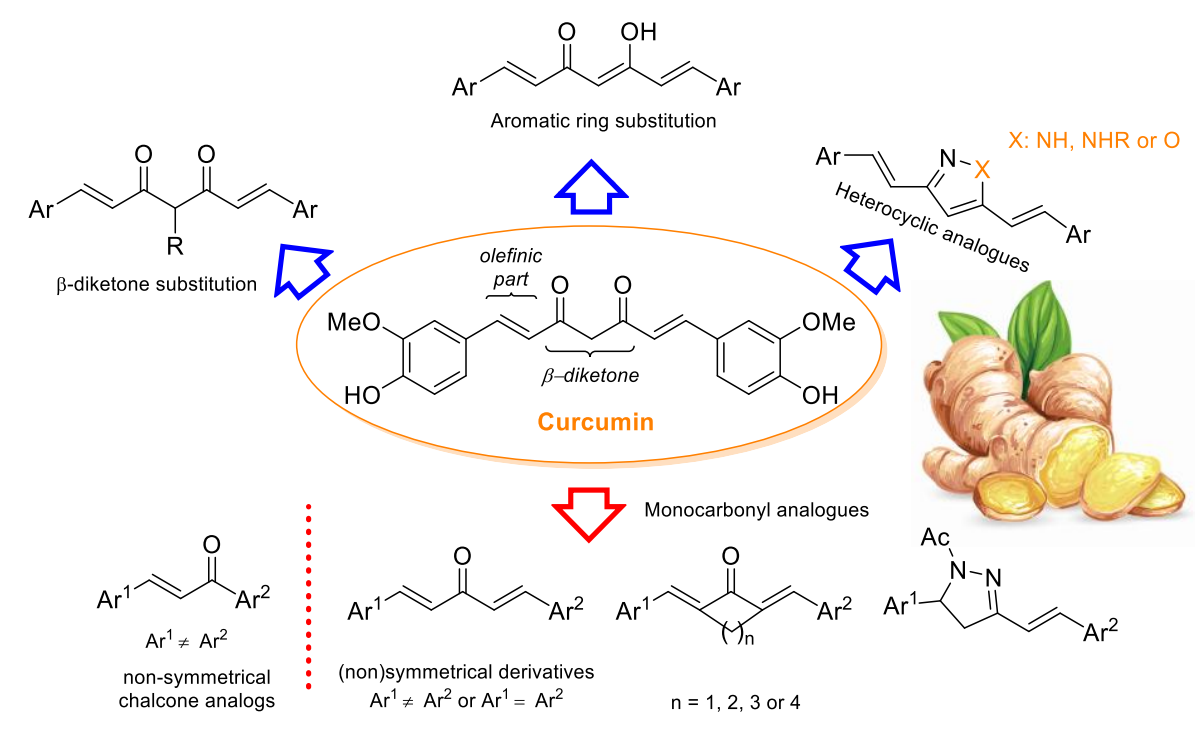

Scheme 3. Possible structural modifications to create curcumin analogs. 

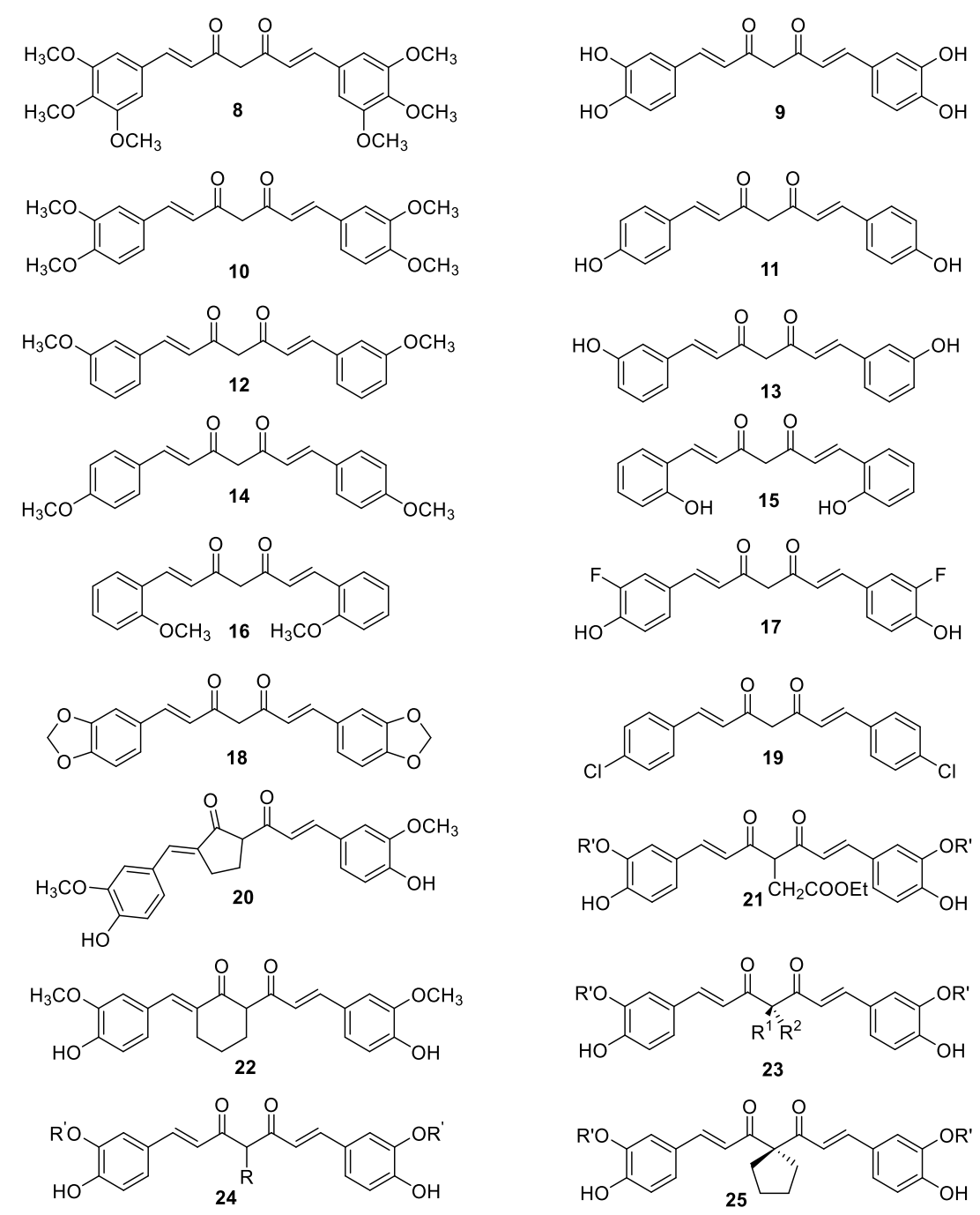

Figure 6. Curcuminoid analogs 8-25.

\subsection{Changes in aromatic ring substitutions}

The antioxidant activity of curcumin $\mathbf{1}$ is not only due to its phenolic groups but also the ortho-methoxy functionality. Thus, it is anticipated that modifications of the substituents on the aromatic moiety will affect antioxidant activity. As mentioned earlier, the ortho-methoxy group can form an intramolecular hydrogen bond with the phenolic hydrogen, facilitating $\mathrm{H}$-atom abstraction from the ortho-methoxy phenols. The scavenging activity significantly decreased in the order THC $(18.7 \mu \mathrm{M}, 5)>\mathrm{HHC}(21.6 \mu \mathrm{M}, 6)=\mathrm{OHC}(23.6 \mu \mathrm{M}$, 7) > Trolox $(31.1 \mu \mathrm{M}) \geq$ curcumin $(35.1 \mu \mathrm{M}, 1)>\operatorname{DMC}(53.4 \mu \mathrm{M}, 3)>>$ BDMC $(>200 \mu \mathrm{M}, 2){ }^{37}$ However, an $^{3}$ increased number of hydroxy groups on the aromatic moiety (e.g. polyhydroxy-curcuminoid 26, Scheme 4) showed interesting antioxidant properties. ${ }^{197}$ Non-phenolic analogs 27-31 were either less active or inactive as antioxidants. It has been suggested that the steric crowding at ortho positions in compounds 32-34 (Scheme 4) contributes to a facile transfer of hydrogen atoms by stabilizing the phenoxy radical and preventing the phenolic group from forming a hydrogen bond with the medium, but when the $R^{2}$ and $R^{4}$ groups were replaced with bulkier tert-butyl groups $\left(\mathrm{C}(\mathrm{Me})_{3}, 35\right)$, antioxidant activity was reduced significantly due to the absence of a hydroxy group compared to $26 .{ }^{198,199}$ 


\begin{tabular}{|c|c|c|c|c|c|}
\hline Compound & $\mathrm{R}^{1}$ & $\mathrm{R}^{2}$ & $\mathrm{R}^{3}$ & $\mathrm{R}^{4}$ & $\mathrm{R}^{5}$ \\
\hline 26 & $\mathrm{H}$ & $\mathrm{OH}$ & $\mathrm{OH}$ & $\mathrm{OH}$ & $\mathrm{H}$ \\
\hline 27 & $\mathrm{H}$ & OMe & OMe & $\mathrm{H}$ & $\mathrm{H}$ \\
\hline 28 & $\mathrm{H}$ & OMe & OMe & OMe & $\mathrm{H}$ \\
\hline 29 & OMe & OMe & OMe & $\mathrm{H}$ & $\mathrm{H}$ \\
\hline 30 & $\mathrm{H}$ & OMe & OMe & $\mathrm{H}$ & OMe \\
\hline 31 & $\mathrm{H}$ & $\mathrm{H}$ & OMe & $\mathrm{H}$ & $\mathrm{H}$ \\
\hline 32 & $\mathrm{H}$ & OMe & $\mathrm{OH}$ & OMe & $\mathrm{H}$ \\
\hline 33 & $\mathrm{H}$ & $\mathrm{OCH}_{2} \mathrm{Me}$ & $\mathrm{OH}$ & $\mathrm{H}$ & $\mathrm{H}$ \\
\hline 34 & $\mathrm{H}$ & Me & $\mathrm{OH}$ & $\mathrm{Me}$ & $\mathrm{H}$ \\
\hline 35 & $\mathrm{H}$ & $\mathrm{C}(\mathrm{Me})_{3}$ & ocome & $\mathrm{C}(\mathrm{Me})_{3}$ & $\mathrm{H}$ \\
\hline
\end{tabular}

Scheme 4. Chemical structures of curcuminoid analogs with aromatic ring substitutions 26-35.

\subsection{Changes in $\beta$-diketone moiety}

5.2.1 Pyrazole and isoxazole analogs. The enol form of curcumin in solution was found to be responsible for its rapid degradation, and hence, to inflate the firmness of the structure, a number of analogs has been synthesized in which the diketone moiety was replaced by an isoxazole or pyrazole group. Interestingly, compounds $\mathbf{3 6}$ and $\mathbf{3 7}$ showed better free radical scavenging activity than curcumin with an $I C_{50}(\mu \mathrm{M})$ value for inhibition of proliferation of the A549 cells upon treatment with $\mathbf{3 7}$ being $3.70 \pm 0.16$ compared to the value of $11.0 \pm 0.59$ for curcumin 1 in RAW 264.7 cells (Figure 7). ${ }^{200}$ Synthesis, characterization and testing of in vitro anticancer activity of a novel series of curcumin analogs to explore potential therapeutics established compound 38, which exhibited the best activity among several compounds tested and may be transformed further into a potential therapeutic. ${ }^{200} \mathrm{~A}$ number of click diarylpentane curcuminoids and their pyrazole derivatives has been synthesized, and this class of compounds validates as novel types of antimiotic agents, recognizing the pyrazole adduct 39 as a promising lead. ${ }^{200}$ Curcumin analogs of benzyloxime and the isoxazole and pyrazole substitutes demonstrated amplification in the antitumor activity both in the parental and in MDR MCF-7 cells. ${ }^{200}$ 

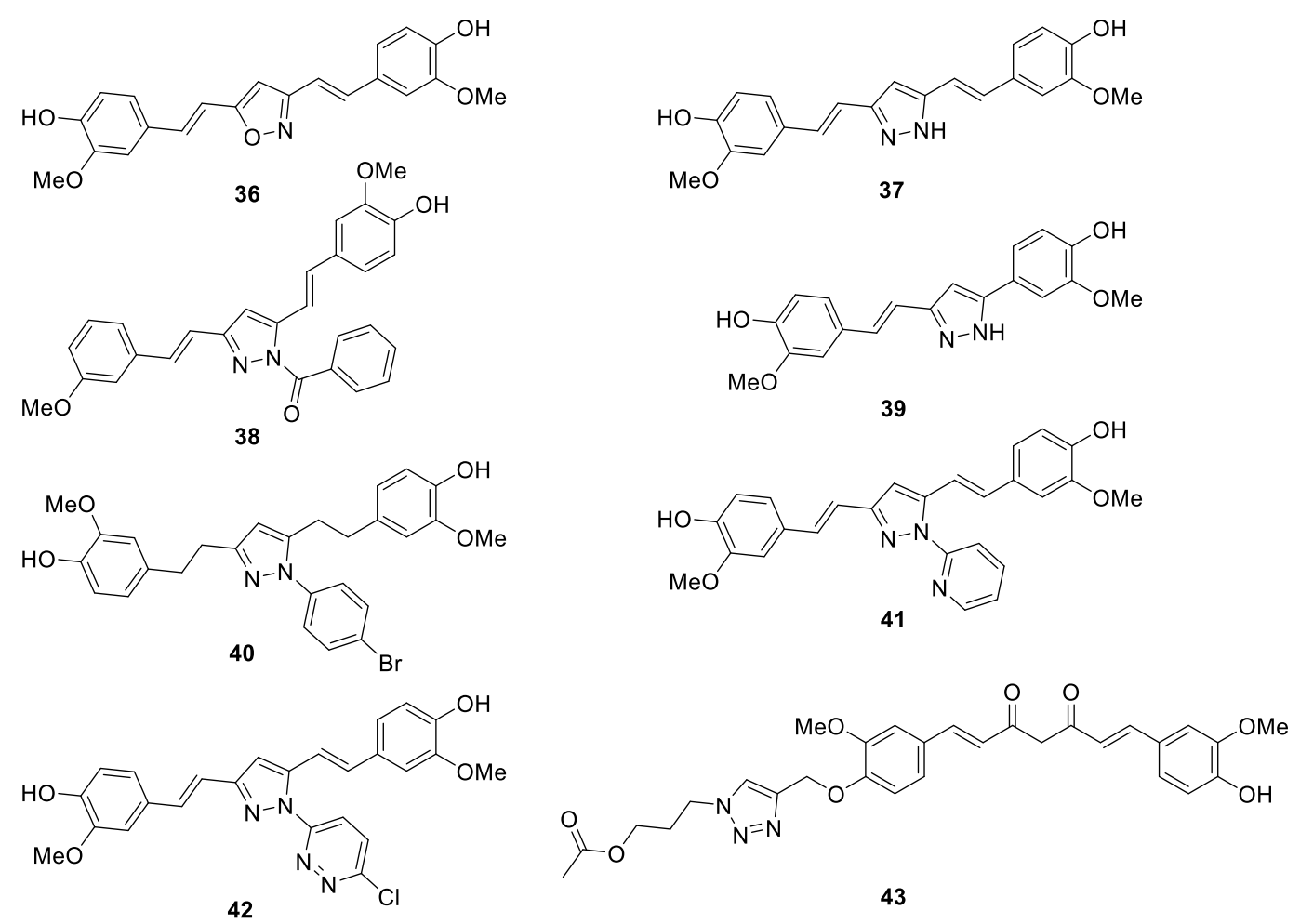

Figure 7. Structures of synthesized curcumin isoxazoles, pyrazoles and their analogs 36-43.

Isoxazole and pyrazole derivatives were shown to be less prone to nucleophilic benzyl mercaptan addition than curcumin itself and demonstrated a better cell growth inhibition and pro-apoptotic effect in liver cancer HA22T/VGH cells as well as other tumor cells. ${ }^{200}$ A series of new pyrazole derivatives of THC, a major metabolite of curcumin, has shown to exhibit excellent anticancer activity against MCF-7 cell lines with good $\mathrm{IC}_{50}$ values. ${ }^{200}$ 4-Bromophenyl derivative $\mathbf{4 0}$ at the pyrazole moiety was the most effective and inhibited the growth of all three tested cell lines with $\mathrm{IC}_{50}$ values of $8.0 \mu \mathrm{M}$ (A549), $9.8 \mu \mathrm{M}$ (HeLa) and 5.8 $\mu \mathrm{M}$ (MCF-7). ${ }^{200}$ Other pyrazole and triazole curcumin analogs have been synthesized and shown to exhibit activity at the micromolar range against head and neck cancer, among which compounds $\mathbf{4 2}$ and $\mathbf{4 3}$ demonstrated potent cytotoxicity values against HNSCC cell lines. Interestingly, compounds $\mathbf{4 1}$ and $\mathbf{4 2}$ appeared to have a pronounced effect on PSTAT3 phosphorylation with compound $\mathbf{4 2}$ being the first reported click chemistry curcumin analog showing good cytotoxic activity. Disruption of pFAK and PAKT phosphorylation signaling is shown with compound $\mathbf{4 3} .{ }^{200} \mathrm{~A}$ number of pyrazole derivatives of penta-1,4-dien-3-one compounds containing a substituted pyrazole were synthesized and some of those showed significant antiproliferative activity against HepG2 cell lines with an $\mathrm{IC}_{50}$ value of 0.10-5.05 $\mu \mathrm{M}$ compared to a value of $16.20 \mu \mathrm{M}$ for Sorafenib. ${ }^{200}$

Pyrazole $\mathbf{4 5}$ and isoxazole $\mathbf{4 7}$ analogs of curcumin $\mathbf{1}$ were produced with different substituents on the active methylene group. For the synthesis of pyrazole derivatives $\mathbf{4 5}$, diketo derivatives $\mathbf{4 4}$ were prepared and reacted in an acid-catalyzed condensation reaction with 1.2 equivalents of hydrazine hydrochloride $\left(\mathrm{NH}_{2} \mathrm{NH}_{2} \cdot \mathrm{HCl}\right)$ in absolute ethanol under reflux for forty hours (Scheme 5). ${ }^{201}$ Likewise, isoxazole derivatives 47 were prepared from compounds 46 using hydroxylamine hydrochloride $\left(\mathrm{NH}_{2} \mathrm{OH} \cdot \mathrm{HCl}\right)$ (Scheme 6). Reported yields were generally high, ranging from $58 \%$ to $90 \%$, with only compound $45 \mathrm{~g}$ having a very low yield of $15 \%$. 


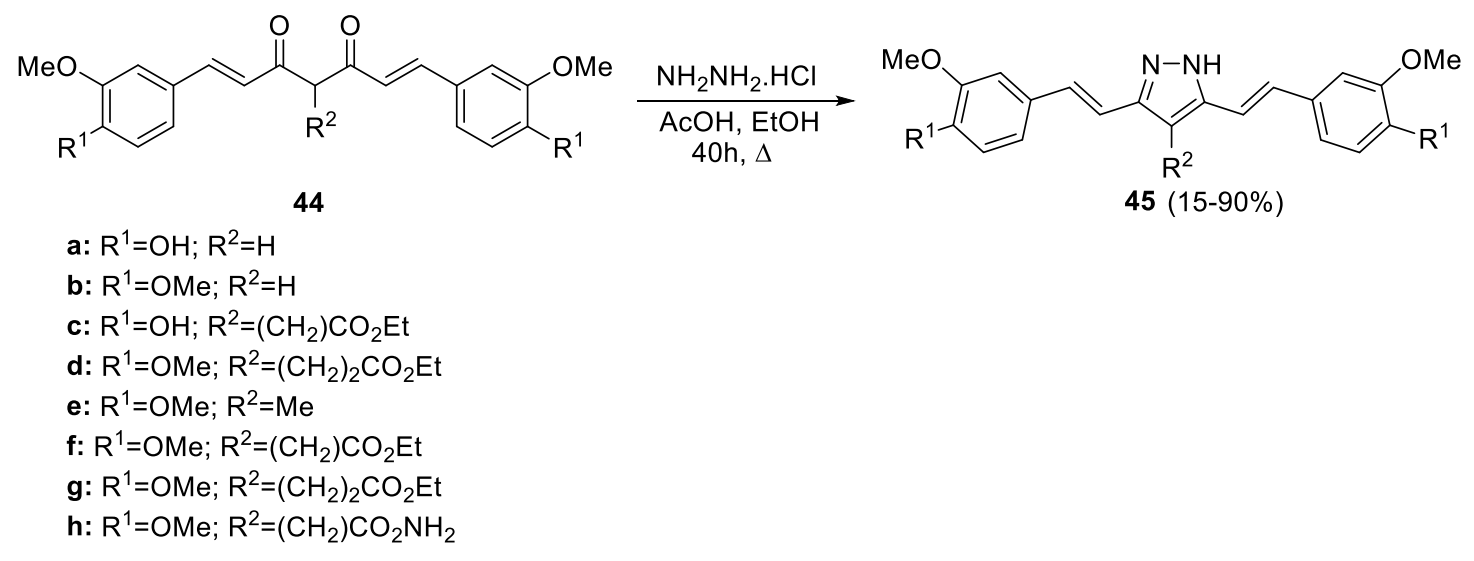

Scheme 5. Knorr pyrazole synthesis of pyrazole curcuminoids 45.

In a study on the investigation of curcumin analogs as antimalarial agents, some new pyrazole derivatives (48a-e) containing an $\mathrm{N}$-phenyl group were prepared (Scheme 7). ${ }^{202}$ For their synthesis, curcumin 1 was dissolved in glacial acetic acid and reacted with 1.25 equivalents of the appropriate hydrazine under reflux. Phenylhydrazine, 4-fluorophenylhydrazine, 3-nitrophenylhydrazine, 2,4-dichlorophenylhydrazine and 4methoxyphenylhydrazine were used to produce the corresponding compounds $48 \mathrm{a}-\mathbf{e}$, respectively. In contrast to previous reactions, low to good yields $(35-71 \%$, Scheme 6) were obtained after a reaction time of 8 hours. ${ }^{202}$ Additionally, analogs 45 a and 47 a were also evaluated for antimalarial activity against Plasmodium falciparum in this study.

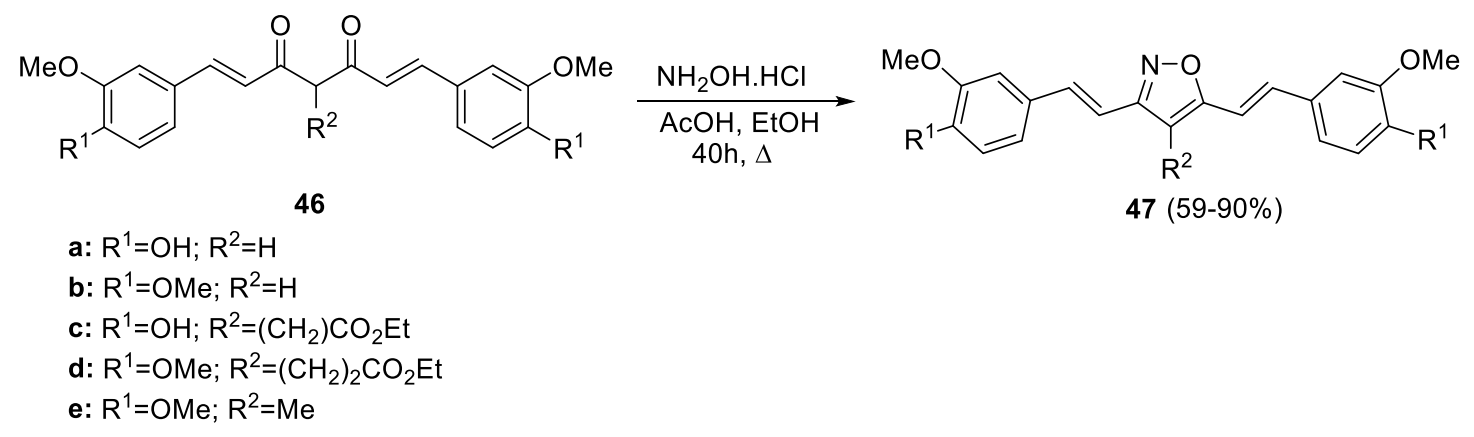

Scheme 6. Synthesis of isoxazole curcuminoids via Paal-Knorr chemistry 47.

These molecules were prepared using a similar procedure as mentioned previously. The study reported good antimalarial activity exerted by compounds $45 \mathrm{a}$ and $48 \mathrm{c}$, with respective $\mathrm{IC}_{50}$ values of $0.48 \pm 0.04 \mu \mathrm{M}$ and $0.87 \pm 0.07 \mu \mathrm{M}$, which is a higher potency compared to curcumin $1(3.25 \pm 0.6 \mu \mathrm{M}) .{ }^{202}$ 


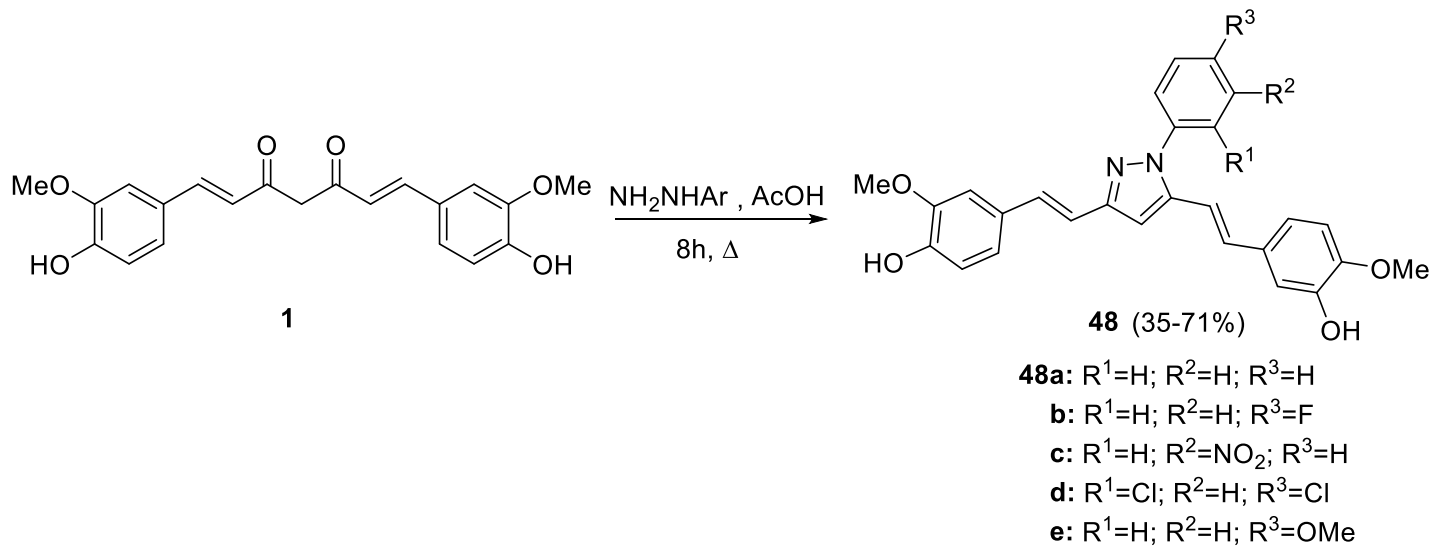

Scheme 7. Synthesis of $N$-arylpyrazole analogs 48.

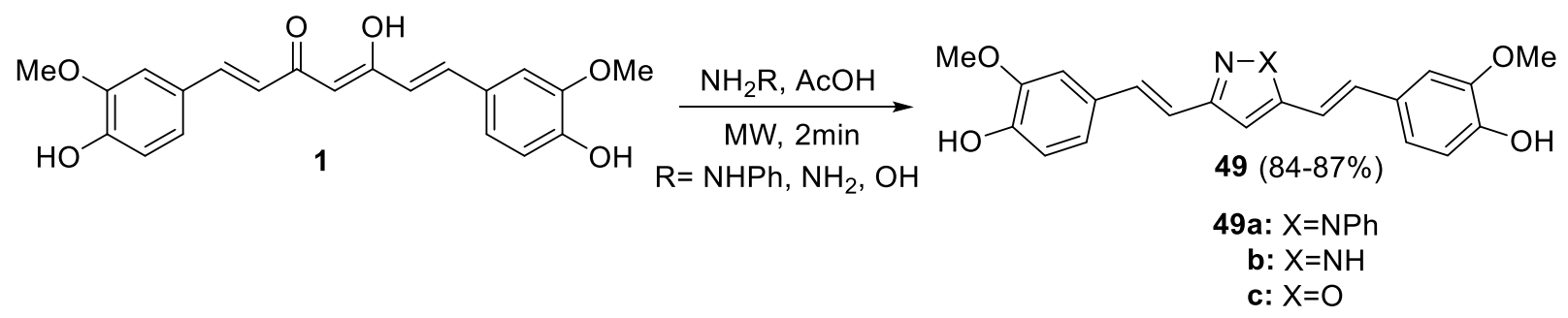

Scheme 8. Synthesis of pyrazole and isoxazole curcuminoids $\mathbf{4 9}$ via microwave irradiation.

Modifications to the conventional synthesis procedure are also possible; for instance, three of the previously discussed isoxazole and pyrazole analogs have been synthesized with the assistance of microwave irradiation (Scheme 8). ${ }^{203}$ Compounds $49 a-c$ correspond to $48 a, 45 a$, and $47 a$. They were produced by reacting an equivalent amount of curcumin $\mathbf{1}$ and hydrazine (phenylhydrazine, hydrazine hydrate, and hydroxylamine hydrochloride, respectively) in $2 \mathrm{~mL}$ of glacial acetic acid for two minutes while being subjected to microwave irradiation. In a modified procedure, three more isoxazole/pyrazole analogs (49a-c) of curcumin 1 were prepared using microwave irradiation. ${ }^{203}$ This short procedure resulted in very high yields (84-87\%). Compared to the duration of conventional reactions which could last from 8 to 40 hours, microwave irradiation seems to hold a remarkable potential in curcumin synthesis. ${ }^{201-203}$

Isoxazole analogs of curcumin exhibited antiproliferative and cell death effects in MCF-7R comparable to those achieved in MCF-7 and cause minor changes in NF-KB or STAT3 activation. ${ }^{200} 4,4^{\prime}-\left(1 E, 1^{\prime} E\right)-2,2^{\prime}-[1-(3-$ chlorophenyl)-1H-pyrazole-3,5-diyl]bis(ethene-2,1-diyl) bis(2-methoxyphenol) showed a high degree of cytotoxicity and cell proliferation inhibition against cancer cells and can be selected for further in vitro and in vivo investigations. ${ }^{200}$ Isoxazole analogs of curcumin exhibited significantly improved in vitro drug-like properties including solubility, metabolic stability, cell permeability and lack of nonspecific cytotoxicity when compared with curcumin. ${ }^{200}$

5.2.2. $\boldsymbol{\beta}$-enaminones. Also $\beta$-enaminone analogs (50a-e) have been prepared in low yields $(25-35 \%)$ by adding the appropriate primary amine to a mixture of curcumin $\mathbf{1}$ and acetic acid (Scheme 9). Any water formed during the reaction was removed via the Dean-Stark setup. ${ }^{204}$ Dioxime analogs 51a-b were prepared by adding a solution of curcumin 1 and two equivalents of $O$-methyl or $O$-benzylhydroxylamine hydrochloride in $25 \%$ water-ethanol (1:3) to a solution of potassium carbonate in water (Scheme 9). ${ }^{204}$ The mixture was then heated under reflux for 25 minutes. Compounds 50a and 50b were obtained in 40\% and 34\% yield, respectively. 


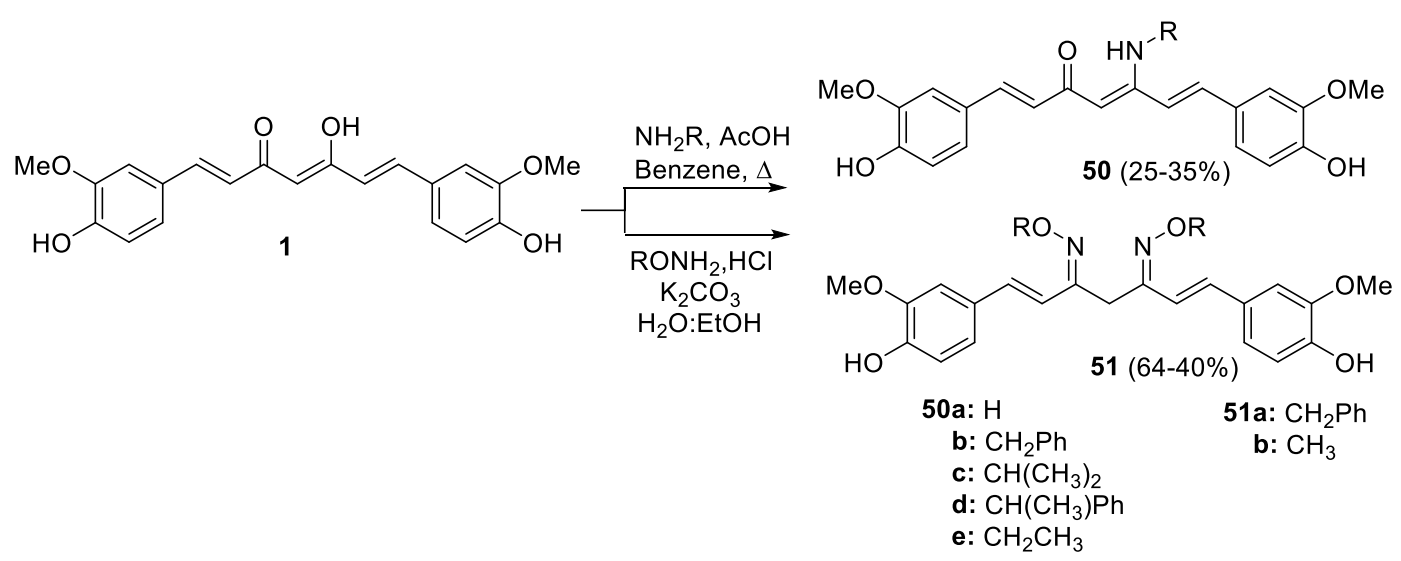

Scheme 9. Synthesis of mono/di- $\beta$-enaminone analogs $\mathbf{5 0}$ and $\mathbf{5 1 .}$

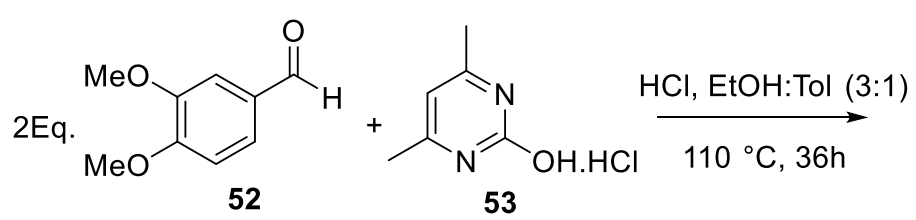<smiles>COc1ccc(/C=C/c2cc(/C=C/c3ccc(OC)c(OC)c3)nc(O)n2)cc1OC</smiles><smiles>COc1ccc(/C=C/c2cc(/C=C/c3ccc(OC)c(OC)c3)nc(NCCC(=O)O)n2)cc1</smiles>

1. $\mathrm{POCl}_{3}$, DIPEA $110^{\circ} \mathrm{C}, 12 \mathrm{~h}$

2. $\mathrm{NH}_{2}\left(\mathrm{CH}_{2}\right)_{n+2} \mathrm{OH}$ $\mathrm{EtOH}, 90^{\circ} \mathrm{C}, 12 \mathrm{~h}$

Scheme 10. Synthesis of pyrimidine-substituted curcumin analogs 55.

For the synthesis of compounds 55, two equivalents of 3,4-dimethoxybenzaldehyde $\mathbf{5 2}$ were reacted with 4,6dimethyl-2-hydroxypyrimidine hydrochloride 53 in a solvent mixture of toluene and ethanol (1:3) with $\mathrm{HCl}$ as the catalyst. The obtained product 54 was then combined with diisopropylethylamine (DIPEA) in an excess of phosphoryl chloride $\left(\mathrm{POCl}_{3}\right)$ at reflux temperature. Here, the hydroxy group of $\mathbf{5 4}$ is substituted by a chlorine (not shown), and this intermediate can in turn react with a selected primary amine in EtOH to form the desired products 55 (Scheme 10). ${ }^{205}$ These compounds have been shown to be active and promote apoptosis against colon cancer (HTC116 cell line), which was consistent with the multiple functions of EGFR signaling pathways.

Sulfonamide-containing curcuminoids $\mathbf{5 7}$ and $\mathbf{5 8}$ can be synthesized from imination with sulfanilamides in ethanol (Scheme 11). ${ }^{206}$ When acetic acid is added as the catalyst, compound $\mathbf{5 7}$ can react with sulfanilamide again and result in 58. These curcumins showed interesting antibacterial properties (against Staphylococcus aureus, Bacillus cereus, Salmonella typhi, Pseudomonas aeruginosa, Escherichia coli: MIC = 20-80 $\mu \mathrm{M})$ and antifungal activities (against Aspergillus niger, Aspergillus flavus, Curvularia lunata, Trichoderma viride: MIC = 40-80 $\mu \mathrm{M})$, as well as moderate cytotoxicity $\left(\mathrm{IC}_{50}\right.$ values $=25-50 \mu \mathrm{M} / \mathrm{mL}$ against HeLa, HepG2, QG-56 and HCT116 cell lines). 


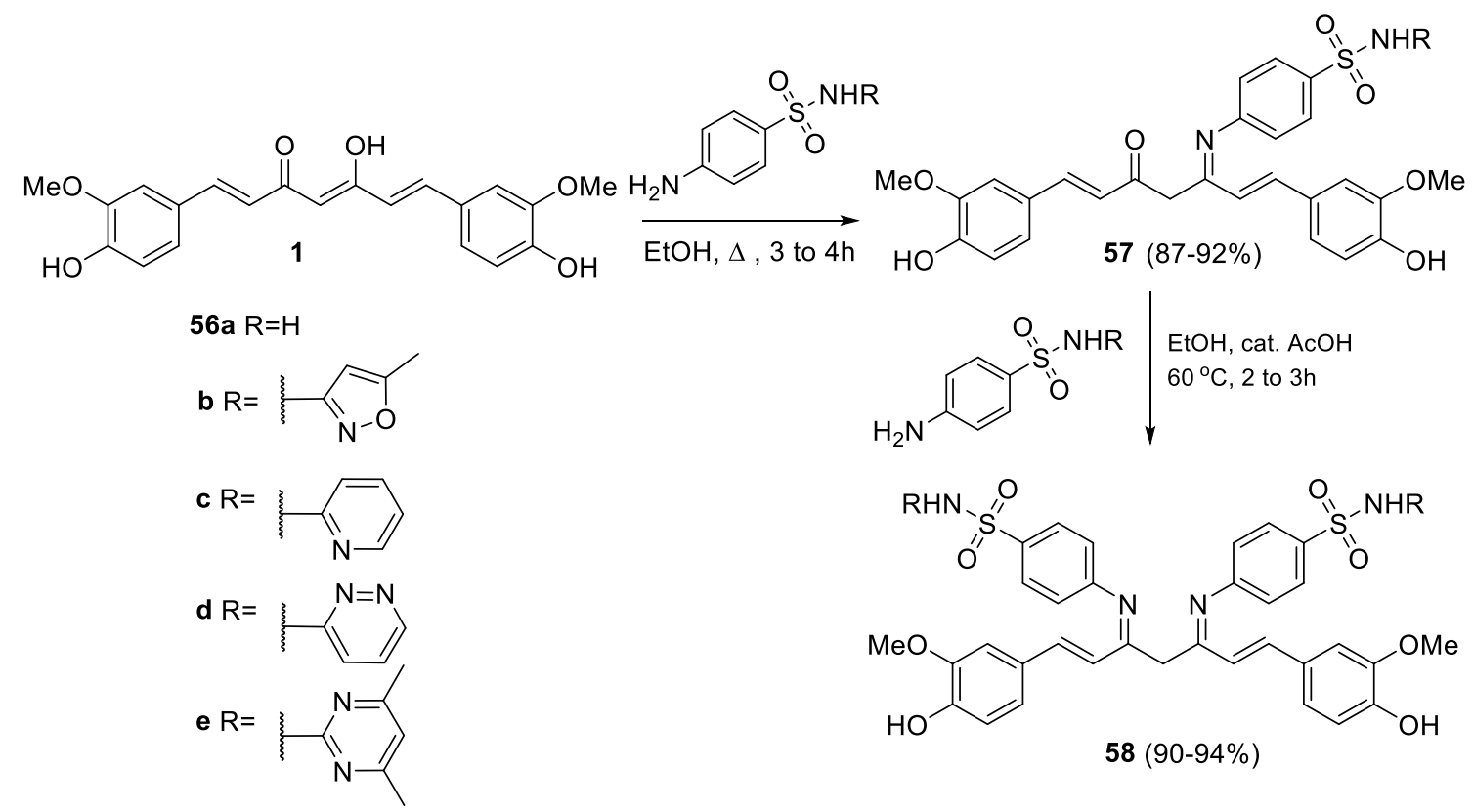

Scheme 11. Synthesis of new derivatives of curcumin containing sulfonamides $\mathbf{5 7}$ and $\mathbf{5 8 .}$

5.2.3. Monocarbonyl analogs of Curcumin (MACs). To contend with research on traditional curcumin, the chemical class of curcumin monocarbonyl analogs has evolved bearing biological properties similar or superior to curcumin itself, furnishing a 10-20 fold potency gain for a number of cancer cell lines and cellular proteins and better pharmacokinetic profiles in mice, as well as higher tumor regression in cancer xenografts in vivo than curcumin. ${ }^{207}$ As the instability of curcumin stems from the methylene group and $\beta$-diketone moiety, the absence of the $\beta$-diketone moiety in monocarbonyl analogs may help enhance its stability. These analogs can be symmetrical, non-symmetrical or cyclic. An example class is made up by replacing the central 1,3-diketo structure by a piperidone skeleton $\mathbf{5 9}$ and $\mathbf{6 0}$ (Figure 8). This class is characterized by a better stability and easier synthesis compared to that of curcumin $1 .{ }^{208,209}$

Compound $\mathbf{5 9}$ has been shown to have good anti-inflammatory activity. ${ }^{188,189} \mathrm{~A}$ more remarkable analog is compound 60, better known as EF24, ${ }^{210-214}$ which has been reported to work more effectively against several cancer cell lines than the regularly used chemotherapeutic drug Cisplatin ${ }^{\oplus}$. In the field of anti-angiogenesis, the potency of compound $\mathbf{6 0}$ approaches the level of the drug TNP-470, an analog of Fumagillin. ${ }^{208,215}$ Further research on piperidone analogs furnished compound 65 that was even more powerful, synthesized by reaction of 2-chlorobenzaldehyde 62 and 4-piperidone hydrochloride 63 in glacial acetic acid (Scheme 12). ${ }^{216}$ The reagents undergo a Claisen-Schmidt condensation, and compound $\mathbf{6 4}$ is formed. Finally, $\mathbf{6 4}$ is reacted with maleic anhydride in the presence of triethylamine $\left(\mathrm{Et}_{3} \mathrm{~N}\right)$ to obtain the desired compound 65 in a yield of $94 \%$.
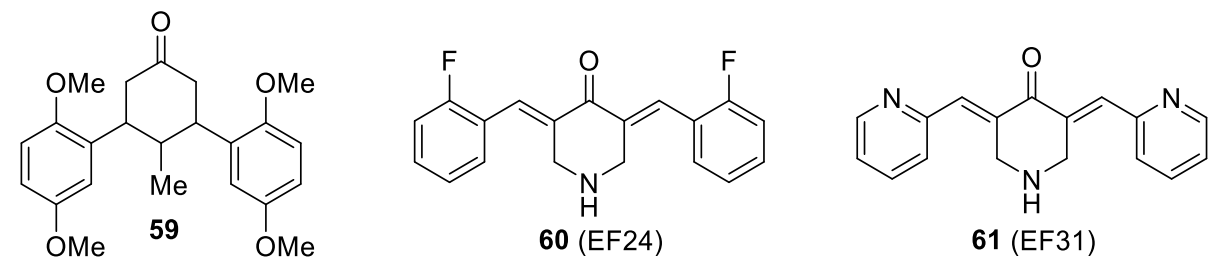

Figure 8. Monocarbonyl curcuminoids 59-61. ${ }^{163,164,204,207}$ 


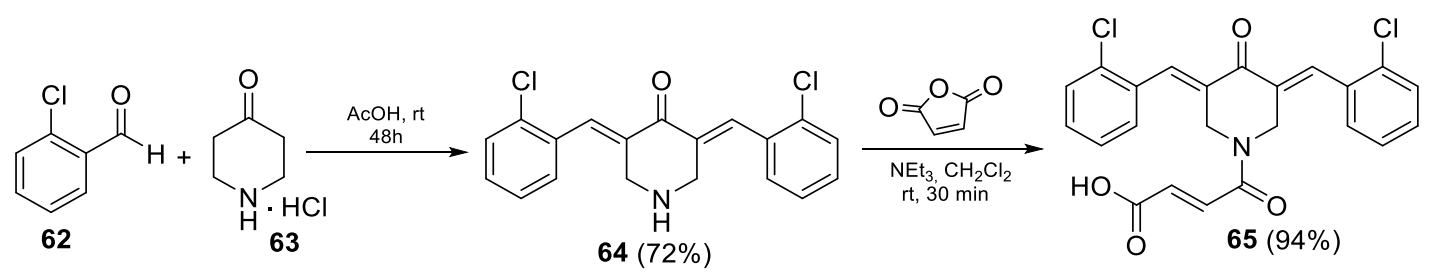

Scheme 12. Synthetic approach towards 3,5-bis(2-chlorobenzylidene)-4-piperidones 64 and synthesis of $N$-acyl derivatives of 3,5-bis(2-chlorobenzylidene)-4-piperidone 65.

MAC curcumin analogs are often assessed in phenotypic assays such as proliferation and angiogenesis by investigators in cancer studies. One of the MACs, EF31 (61, Figure 8) has shown to be able to block 22 of 50 cancer-related kinases by a recent modest kinase screen. ${ }^{207}$ In addition to other techniques, glycosylation is also known to significantly alter the properties of small molecules and therefore concerns a frequently applied modification of drug-like compounds. For example, glycosylation can enhance water solubility and the stability and/or bioactivity of target structures. In that respect, the glycosylation of curcumin has been explored intensively in the literature, e.g. culminating in efficient biocatalytic methodologies to efficiently produce curcumin (di)glucoside. ${ }^{217}$

A series of symmetric piperidones 66-89 (Figures 9 and 10) has been synthesized to evaluate cytotoxic effects using murine P388 and L1210 cells as well as human Molt4/C8 and CEM T lymphocytes, amongst which the average value for the $\mathrm{N}$-acrolyl analogs $\mathbf{7 5 - 8 1}$ being $1.8 \mu \mathrm{M}$ for the four cell lines while the $\mathrm{N}$-unsubstituted compounds 82-88 furnished a higher average of $44 \mu \mathrm{M}$, for which the electronic parameters were deemed the most important factor influencing cytotoxicity. ${ }^{207}$
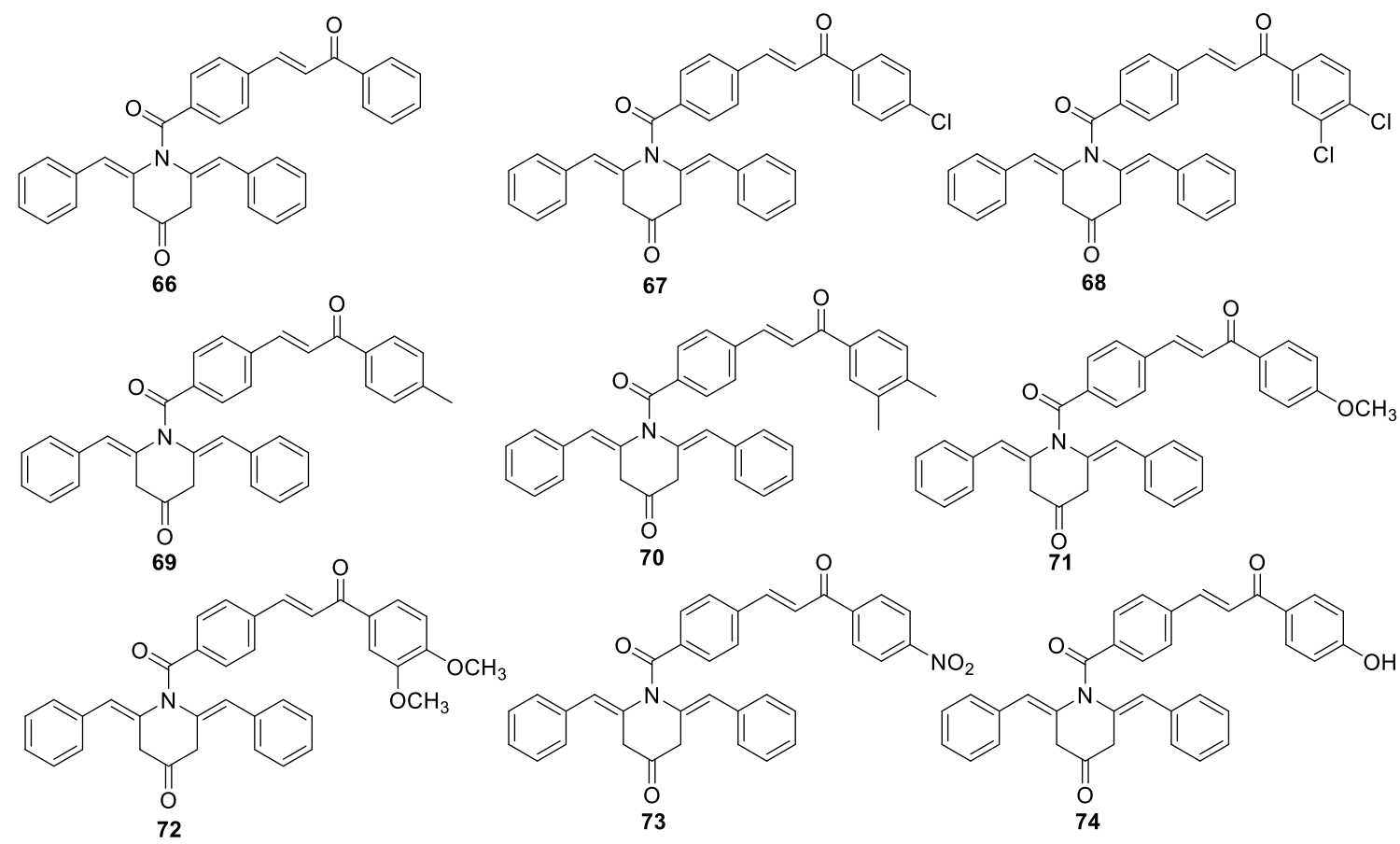

Figure 9. Structures of anticancer MACs 66-74.

Another series of MACs 89-97 (Figure 10) was produced and tested for anti-proliferation and anti-angiogenic activity. Analogs 60 (EF24), 91, 92 and 93 showed cytotoxicity better than cisplatin being effective in anti- 
proliferation assays as well as efficacious in anti-angiogenesis assays. ${ }^{207}$ The data suggest that (i) the symmetrical $\alpha, \beta$-unsaturated ketone moiety installed shows a superior anticancer activity compared to the $\beta$ diketone structure of curcumin; (ii) ortho-substitution on aromatic rings (91-93, Figure 10) increases the activity compared to the meta- or para-substitutions $(\mathbf{9 5}, \mathbf{9 6}$, Figure 10) being a little less active; and (iii) a heteroatom in the cyclic ketone (92, 93 and 97, Figure 10) generally results in improved anticancer and antiangiogenic activity. Compound $\mathbf{9 0}$ was further investigated and found to decrease cell viability of lung cancer cells, and an interesting observation was made in context of its anti-hypoxia inducible factor(HIF)-1 activity compared to curcumin: while curcumin inhibited HIF-1 $\alpha$ gene transcription, 90 inhibited HIF-1 $\alpha$ posttranscriptionally, and also curcumin brings out microtubule stabilization in cells, whereas 90 has no effect. ${ }^{207}$

Symmetrical 1,5-diarylpentanediones 98-102 (Figure 11) were produced, synthesized and tested against cell growth of colon cancer cells. The compound $\mathbf{9 9}$ was determined to exhibit a four times higher potency than curcumin with an $\mathrm{IC}_{50}$ value of $2 \mu \mathrm{M}$ compared to a value of $8 \mu \mathrm{M}$ for curcumin. ${ }^{207}$ Compounds 103-106 were evaluated by means of anti-proliferation and anti-angiogenic assays. Anti-angiogenic activity was demonstrated by considerable reduction of micro vessel density in peritoneum wall sections in Ehrlich ascites tumor mouse models. The two aromatic regions were interpreted to be critical for potential drug-protein interactions from the study. ${ }^{207}$

Among the aromatic enone and dienone analogs 107-115 showing cell proliferation upon being screened in an in vitro anti-angiogenic assay, $\mathbf{1 1 1}$ and $\mathbf{1 1 4}$ were found to be particularly potent, indicating the importance of heterocyclic substitution. The same group subsequently came up with generated derivatives with variation in the substitution pattern of benzene rings or fusion characteristics, systems 116-119 being the most important, which are structurally tetralones introducing rigidity in the molecule. The 2-napthyl analog 117 exhibited the best anti-angiogenic activity, $85 \%$ at $1 \mu \mathrm{g} / \mathrm{mL}$ in the sequence $117>118>116>119 .{ }^{207}$ 


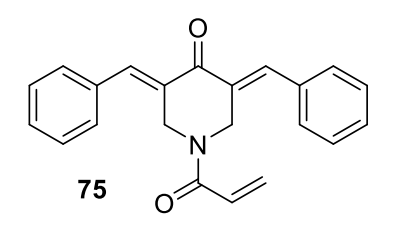<smiles>C=CC(=O)N1C/C(=C\c2ccc(Cl)cc2)C(=O)/C(=C/c2ccc(Cl)cc2)C1</smiles><smiles>C=CC(=O)N1C/C(=C\c2ccc(Cl)c(Cl)c2)C(=O)/C(=C/c2ccc(Cl)c(Cl)c2)C1</smiles><smiles>C=CC(=O)N1C/C(=C\c2ccc(F)cc2)C(=O)/C(=C/c2ccc(F)cc2)C1</smiles><smiles>C=CC(=O)N1C/C(=C\c2ccc([N+](=O)[O-])cc2)C(=O)/C(=C/c2ccc(N(C)C)cc2)C(=O)/C1=C\c1ccc(N(C)C(=O)C=C)cc1</smiles><smiles>C=CC(=O)N1C/C(=C\c2ccc(OC)cc2)C(=O)/C(=C/c2ccc(OC)cc2)C1</smiles><smiles>O=C1/C(=C/c2ccccc2)CNC/C1=C\c1ccccc1</smiles><smiles>O=C1/C(=C/c2ccc(Cl)cc2)CNC/C1=C\c1ccc(Cl)cc1</smiles><smiles>O=C1/C(=C/c2ccc(Cl)c(Cl)c2)CNC/C1=C\c1ccc(Cl)c(Cl)c1</smiles><smiles>O=C1/C(=C/c2ccc(F)cc2)CNC/C1=C\c1ccc(F)cc1</smiles><smiles>O=C1/C(=C/c2ccc([N+](=O)[O-])cc2)CNC/C1=C\c1ccc([N+](=O)[O-])cc1</smiles><smiles>COc1ccc(/C=C2\CNC/C(=C\c3ccc(OCN(C)c4ccc(/C=C5\CNC/C(=C\c6ccc(N(C)C)cc6)C5=O)cc4)cc3)C2=O)cc1</smiles><smiles>C=CC(=O)N1C/C(=C\c2ccccc2)C(=O)/C(=C/c2ccccc2)C1</smiles><smiles>O=C1/C(=C/c2ccccc2O)CCC/C1=C\c1ccccc1O</smiles><smiles>O=C1/C(=C/c2ccccc2O)COC/C1=C\c1ccccc1O</smiles><smiles>CN1C/C(=C\c2ccccc2O)C(=O)/C(=C/c2ccccc2O)C1</smiles><smiles>CC(=O)N1C/C(=C\c2ccccc2F)C(=O)/C(=C/c2ccccc2F)C1</smiles><smiles>O=C(/C=C/c1ccccc1O)/C=C/c1ccccc1O</smiles><smiles>O=C(/C=C/c1ccc(O)cc1)/C=C/c1ccc(O)cc1</smiles><smiles>O=C(/C=C/c1cccc(O)c1)/C=C/c1cccc(O)c1</smiles><smiles>O=C1/C(=C/c2ccccc2F)COC/C1=C\c1ccccc1F</smiles>

Figure 10. Structures of anticancer MACs 75-97. 


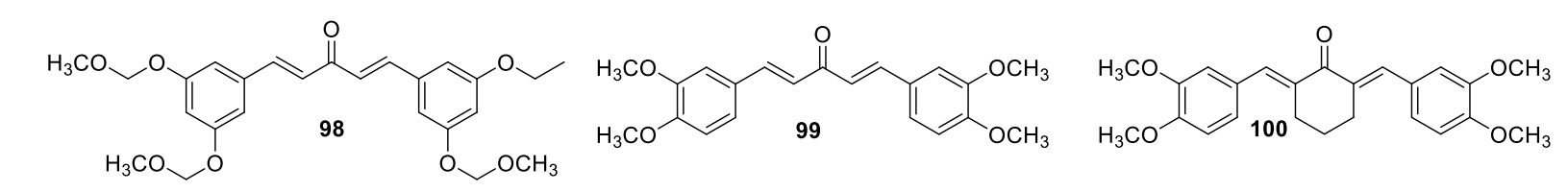

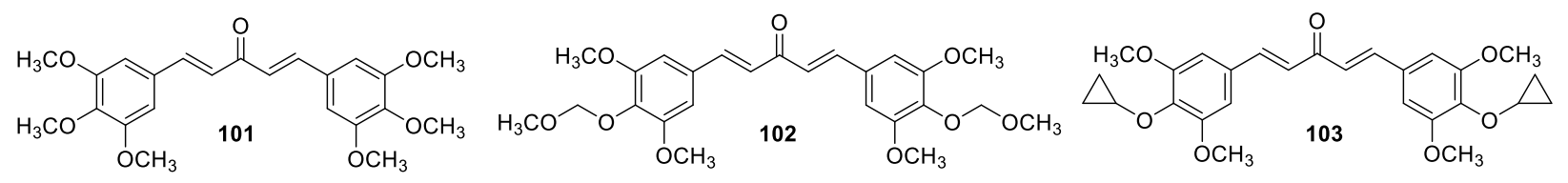

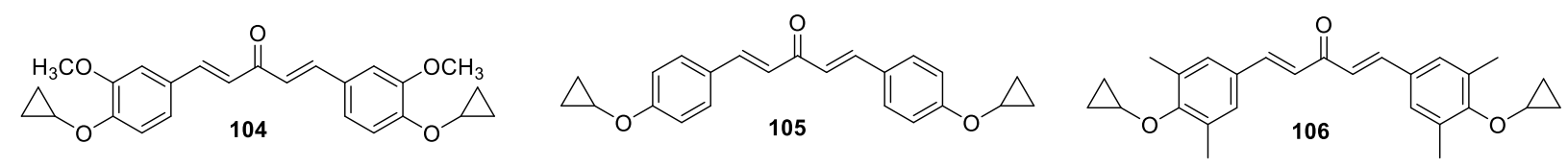
(107) (112<smiles>O=C1/C(=C/c2ccccc2)Cc2ccccc21</smiles><smiles>O=C1/C(=C/c2cc3ccccc3cc2[In])Cc2ccccc21</smiles><smiles>O=C1/C(=C/c2c(Cl)cccc2Cl)[C@H]2CC[C@@H]1c1ccccc12</smiles><smiles>O=C1/C(=C/c2cccc3ccccc23)Cc2ccccc21</smiles>

Figure 11. Structures of anticancer MACs 98-119.<smiles>COc1cc(/C=C/c2ccc(/C=C/c3cccc(NC(=O)C(C)C)c3)c(OC)c2)ccc1O</smiles><smiles>CCCCCCCC(=O)c1cccc(NC(C)=O)c1</smiles><smiles>CCCC(=O)Nc1cccc(C(=O)/C=C/c2ccc(O)c(OC)c2)c1</smiles><smiles>COc1cc(/C=C/C(=O)c2cccc(NC(=O)c3ccccc3)c2)ccc1O</smiles><smiles>CCC(=O)OC(=O)Nc1cccc(C(=O)/C=C/c2ccc(O)c(OC)c2)c1</smiles><smiles>COC(=O)CCC(=O)Nc1cccc(C(=O)/C=C/c2ccc(O)c(OC)c2)c1</smiles><smiles>COc1cc(/C=C/C(=O)c2cccc(NC(=O)c3c(Cl)cccc3Cl)c2)ccc1O</smiles><smiles>COc1cc(/C=C/C(=O)c2cccc(NC(=O)c3ccc(Cl)cc3)c2)ccc1O</smiles><smiles>COc1cc(/C=C/C(=O)c2cccc(NC(=O)c3ccc(Cl)cc3Cl)c2)ccc1O</smiles>

129<smiles>COc1cc(/C=C/C(=O)c2cccc(NC(=O)c3ccc(Cl)c(Cl)c3)c2)ccc1O</smiles><smiles>COc1cc(/C=C/C(=O)c2cccc(NC(=O)c3cc(Cl)cc(Cl)c3)c2)ccc1O</smiles><smiles>COc1cc(/C=C/C(=O)c2cccc(NC(=O)c3ccco3)c2)ccc1O</smiles>

130<smiles>COc1cc(/C=C/C(=O)c2cccc(NC(=O)c3cccs3)c2)ccc1O</smiles>

Figure 12. Structures of anticancer MACs 120-133. 
A series of non-symmetrical MAC chalcones was conceived by coupling substituted phenyl amides with the terminal curcumin styrene unit with $m-\mathrm{OMe}$ and $p-\mathrm{OH}$ substitution, giving rise to structures 120-133 (Figure 12). The particular importance of non-symmetrical phenyl alkyl amides coupled with heteroaromatic moieties is suggested by the potent anti-antigiogenic activity of 129, 130, 132 and 133 due to in vitro growth inhibition of human umbilical vein endothelial cells (HUVEC). ${ }^{207}$

A series of highly polar MACs 134-149 (Figure 13) was synthesized by replacement of the keto-enol functionality by a substituted piperidone, and the compounds 141-149 were found to be significantly more potent than the control agent Melphalan in inhibition of leukemia and colon cancer cell lines in human Molt 4/C8 cells and CEM T-lymphocytes, but compounds 134-140 lost activity. The change in potential can be attributed to the geometric disposition of the double bond configuration within the framework of piperidone substituents.
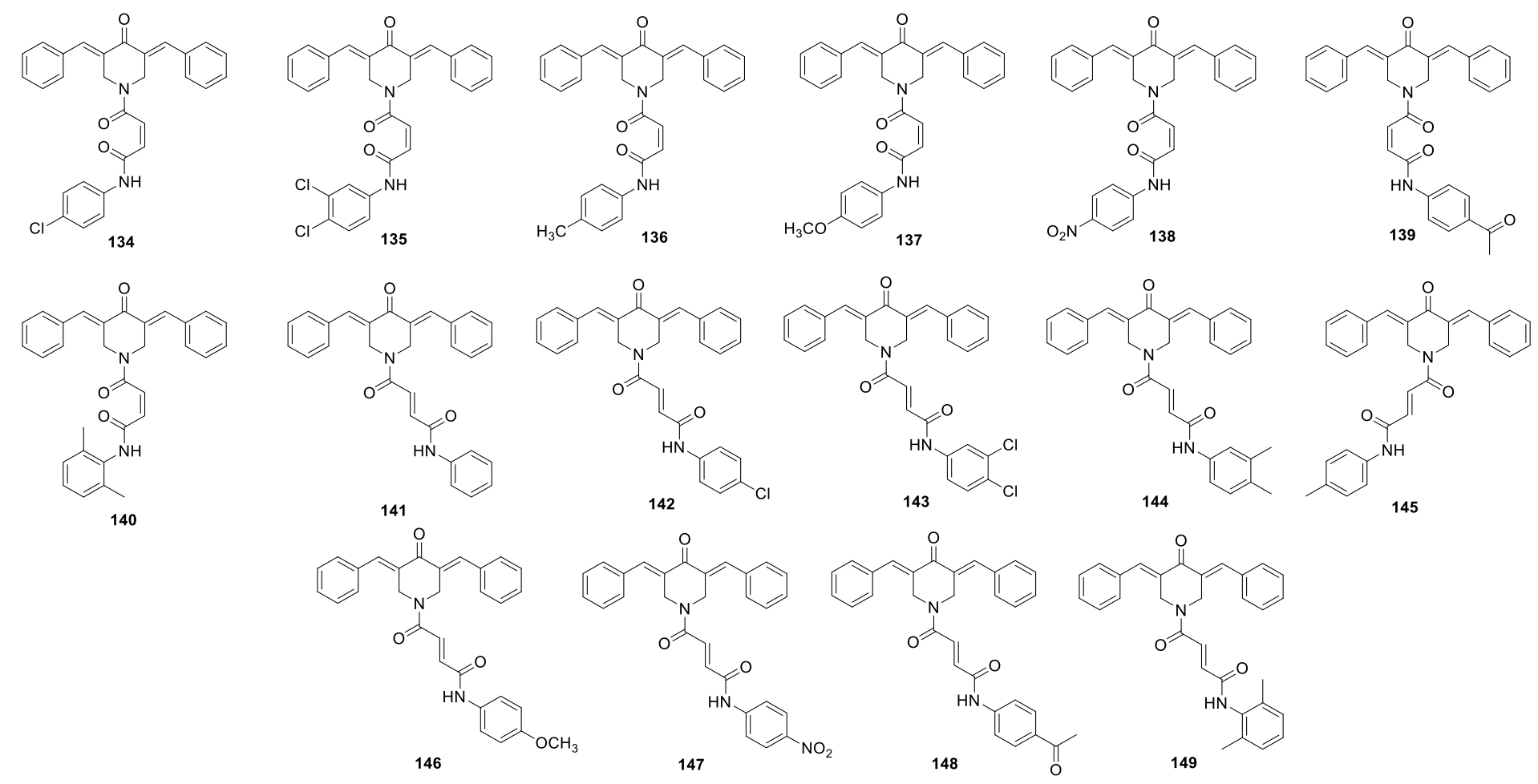

Figure 13. Structures of anticancer MACs 134-149. 
<smiles>COc1cc(/C=C/C(=O)/C=C/c2ccc(O)c(OC)c2)ccc1O</smiles><smiles>COc1ccc(/C=C/C(=O)/C=C/c2ccc(OC)c(OC)c2)cc1OC</smiles><smiles>CC(C)(C)C=CC(=O)C=Cc1ccc(S(N)(=O)=O)cc1</smiles><smiles>COc1cc(OC)c(OC)cc1/C=C/C(=O)/C=C/c1cc(OC)c(OC)cc1OC</smiles><smiles>O=C(/C=C/c1ccccc1)/C=C/c1ccccc1</smiles><smiles>COc1ccc(/C=C/C(=O)/C=C/c2ccc(OC)c(O)c2)cc1O</smiles><smiles>COc1cc(/C=C/C(=O)/C=C/c2cc(OC)c(S(N)(=O)=O)c(OC)c2)cc(OC)c1S(N)(=O)=O</smiles>

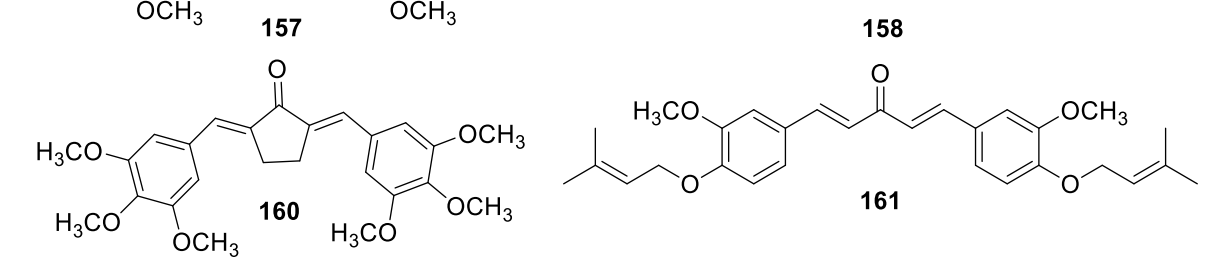<smiles>COc1cc(/C=C/C(/C=C/c2ccc(O)c(OC)c2)=C(C#N)C#N)ccc1O</smiles>
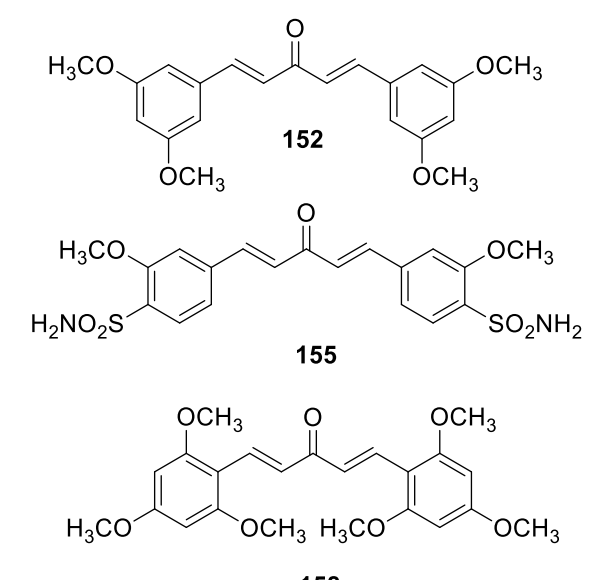

Figure 14. Structures of anticancer MACs 150-162.

A collection of largely acyclic MACs 150-162 (Figure 14) has been synthesized, and their antitumor activity was tested by blocking the proliferation of prostate and breast cancer cells, out of which compound 158 bearing three methoxy groups was found particularly active with an $\mathrm{IC}_{50}$ within the $\mu \mathrm{M}$ range. ${ }^{207}$ The compounds 163175 (Figure 15) were reported to be cytotoxic to the human colon cancer cell line HCT-116. ${ }^{207}$ This study highlighted the structural motifs for bis(arylmethylidene)acetone and 3-oxo-1,4-pentadiene and the dress of substitution being important for maintaining high levels of cell cytotoxicity. Structurally similar compounds 176 and 177 were presented to induce tumor cell apoptosis by activating the stress mechanism of endoplasmic reticulum by another group and have been reported to be under preclinical study for non-small cell lung cancer. ${ }^{207}$ Compounds 178 and 179 also inhibited phosphorylation of STAT3 in breast and prostate cancer cells. Another series of novel 3,5-bis(arylidene)-4-piperidone based symmetrical MACs was screened for their potential anticancer activity, with compounds 180 and 181 showing inhibition against many human cell lines. 

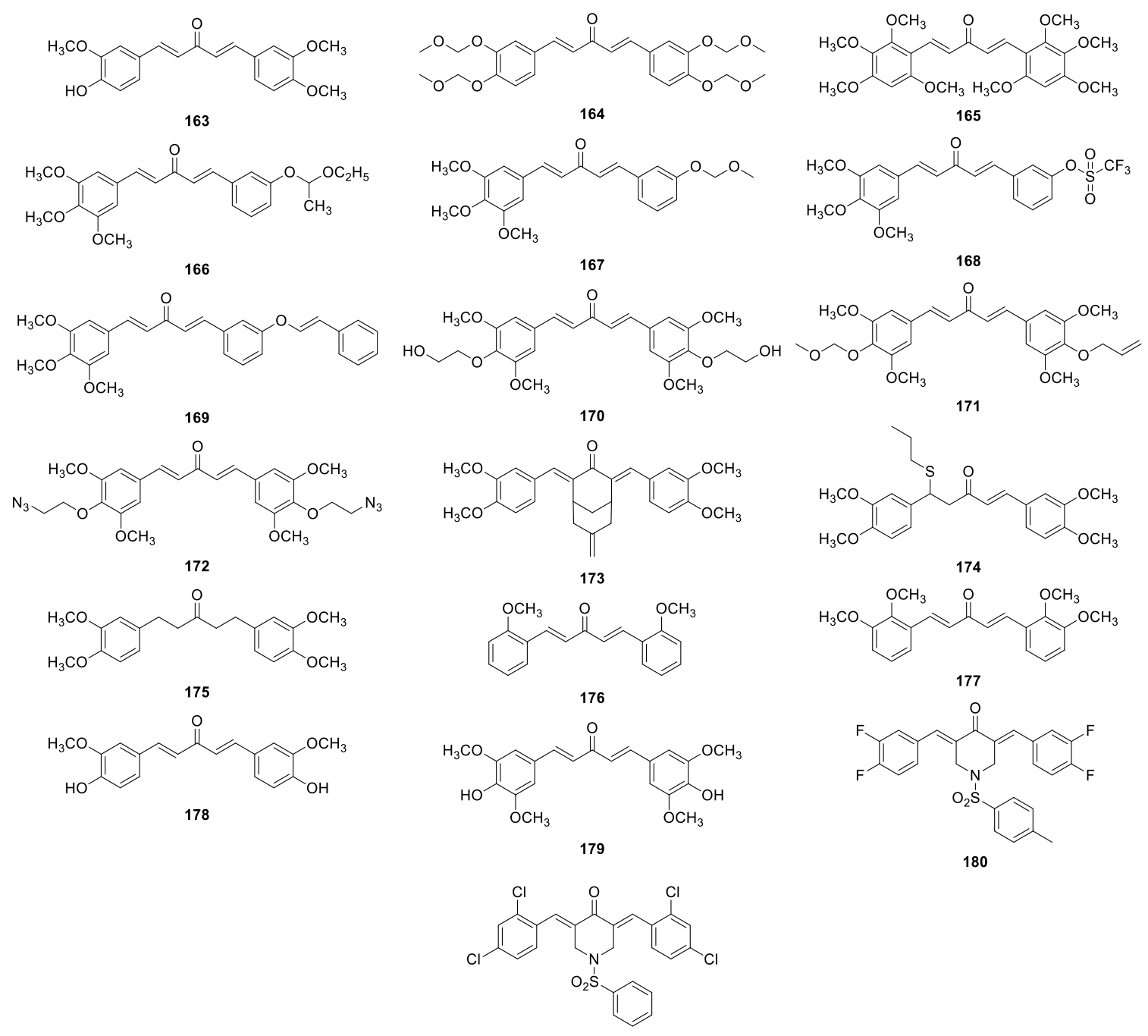

181

Figure 15. Structures of anticancer MACs 163-181.

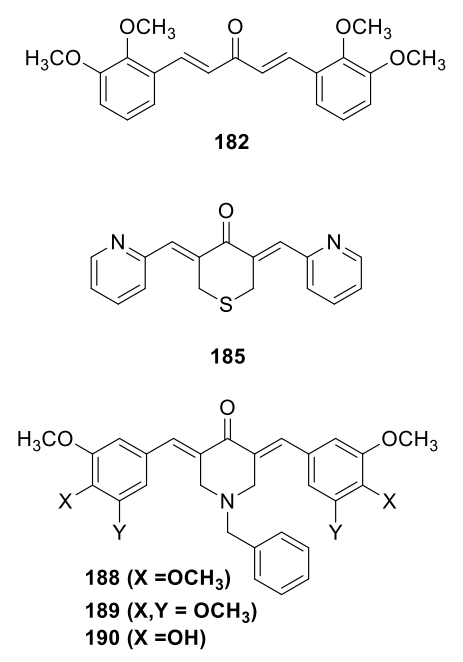

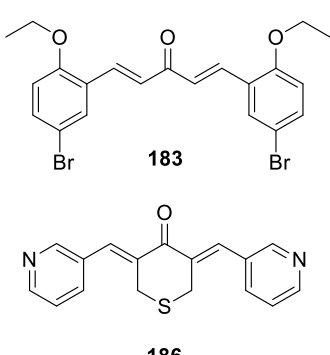

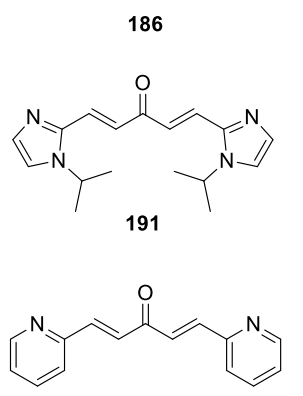

193

Figure 16. Structures of anticancer MACs 182-193. 
More recently, compound 182 (Figure 16) has been determined to elicit an anti-angiogenic activity by suppressing the downstream protein kinase activation of vascular endothelial growth factor (VEGF) via decreasing phosphorylation of AKT and p38. Compound $\mathbf{1 8 3}$ was also reported to display an antitumor effect in the MTT cell proliferation assay using a $\mathrm{H} 460$ non-small cell lung cancer cell line. ${ }^{207}$ A Guangzhou-New Jersey collaboration reported an in vitro activity for two series of analogs, thiopyran-4-ones 184-187 and the benzyl piperidones $\mathbf{1 8 8 - 1 9 0}$ (Figure 16). The thiopyranones were shown to deliver suppressive $I C_{50}$ values $<1$ $\mu \mathrm{M}$ upon testing in an MTT proliferation assay against prostate PC-3, HT-29 colon and Panc-1 cancer cell lines. In a parallel study with benzyl piperidones 188-190, PC-3, pancreas BxPC-2, HT-29, and H1299 lung cancer cell lines were probed with growth inhibition, MTT and trypan blue exclusion assays and the compounds were found to be active with $\mathrm{IC}_{50}$ values $<2 \mu \mathrm{M}$. $^{207}$ Structures 191-193 (as nitrogen-containing heterocyclic derivatives) were reported to furnish anti-prostate cytotoxicity $\mathrm{IC}_{50}$ values of 50-390 $\mathrm{nM}$ and no toxicity against MCF-10A normal mammary epithelial cells.
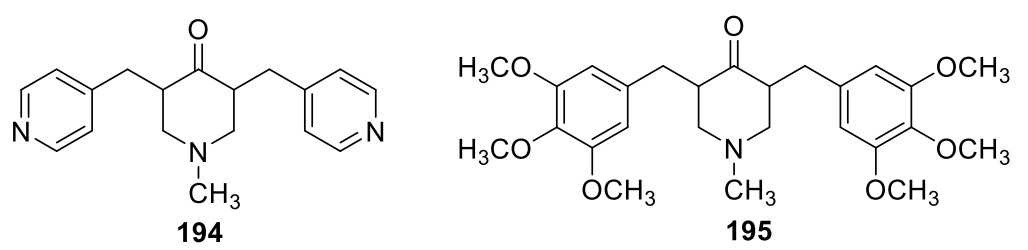

Figure 17. Structures of anticancer MACs 194-195.

Finally, two piperidines 194 and 195 (Figure 17) displayed inhibition of the $\mathrm{kB}$ activation complemented by substantial toxicity towards MBA-MB-231, MDA-MB-468 and SkBr3 breast cancer cell lines; models for triple cancer. Against the MBA-MB-231 cell line, the $\mathrm{EC}_{50}$ values are submicromolar at 0.8 and 0.3 , respectively, while they cause apoptosis in $40 \%-45 \%$ of the SKBr3 and MDA-MB-231 cells. ${ }^{207}$

\subsection{Modification of both the aromatic rings and the $\boldsymbol{\beta}$-diketone moiety}

A part of the recent research in our lab has intensively focussed on the synthesis and evaluation of novel curcuminoids and their evaluation as anticancer agents. In view of the problem of low bioavailability being associated partly with the labile $\beta$-diketo structure, thirteen $\mathrm{N}$-alkyl enaminones 196-208 (and bis-acetylated curcumin 209) were synthesized starting from curcumin 1 and bisdemethoxycurcumin 2 using montmorillonite K10 clay and microwave irradiation (Scheme 13), and a number of nitrogen derivatives showed promising effects upon characterization in terms of solubility, chemical antioxidant properties and in screening assays for cell toxicity, growth and oxidative stress using CHO-K1, EA.hy926, HT-29 and Caco-2 cell lines. It was concluded that the cellular responses are strongly increased by $\mathrm{N}$-analogs, and all the compounds appeared to induce no toxicity effects on differentiated intestinal cells. ${ }^{18}$ 

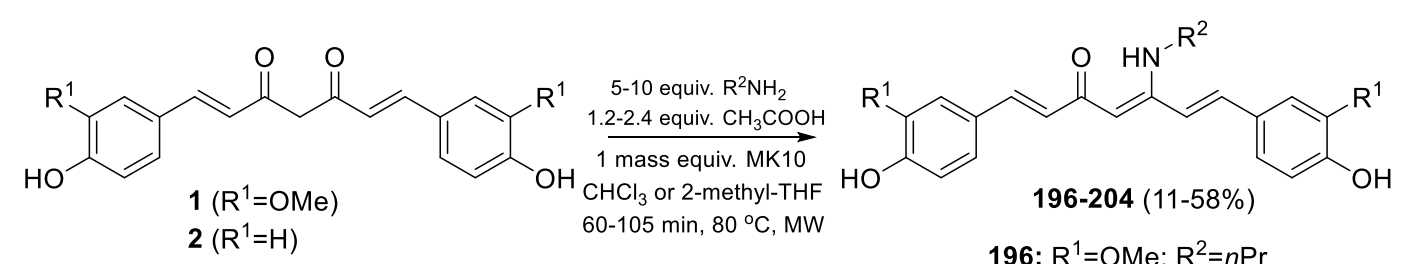

196: $\mathrm{R}^{1}=\mathrm{OMe} ; \mathrm{R}^{2}=n \mathrm{Pr}$

197: $R^{1}=O M e ; R^{2}=$ allyl

198: $\mathrm{R}^{1}=\mathrm{OMe} ; \mathrm{R}^{2}=n \mathrm{Bu}$

199: $R^{1}=O M e ; R^{2}=i B u$

200: $R^{1}=O M e ; R^{2}=s e c B u$

201: $\mathrm{R}^{1}=\mathrm{OMe} ; \mathrm{R}^{2}=c \mathrm{Hex}$

202: $\mathrm{R}^{1}=\mathrm{H} ; \mathrm{R}^{2}=i \mathrm{Bu}$

203: $R^{1}=H ; R^{2}=\sec B u$

204: $\mathrm{R}^{1}=\mathrm{H} ; \mathrm{R}^{2}=c \mathrm{Hex}$
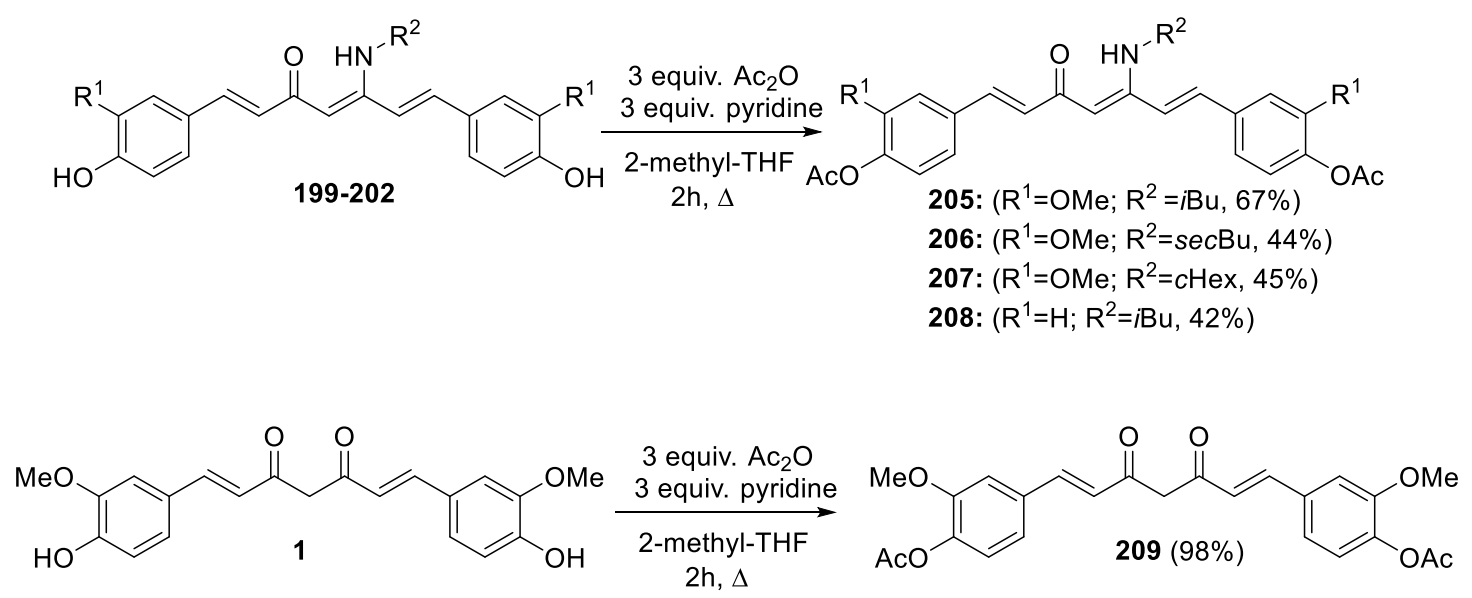

Scheme 13. Synthesis of $\beta$-enaminones 196-208 and bis-acetylated curcumin 209.

New analogs 210-217 (Scheme 14) were then prepared in continuation of this work using more polar amines with an aim of improving water solubility without altering the biological activity of the resulting curcuminoids, again starting from curcumin $\mathbf{1}$ and bisdemethoxycurcumin $\mathbf{2}$ and employing different solvents to minimize the formation of side products 218-220. The resulting $\beta$-enaminones displayed activities better than or comparable to curcumin, and water solubility was also found to be improved significantly. ${ }^{19}$ 


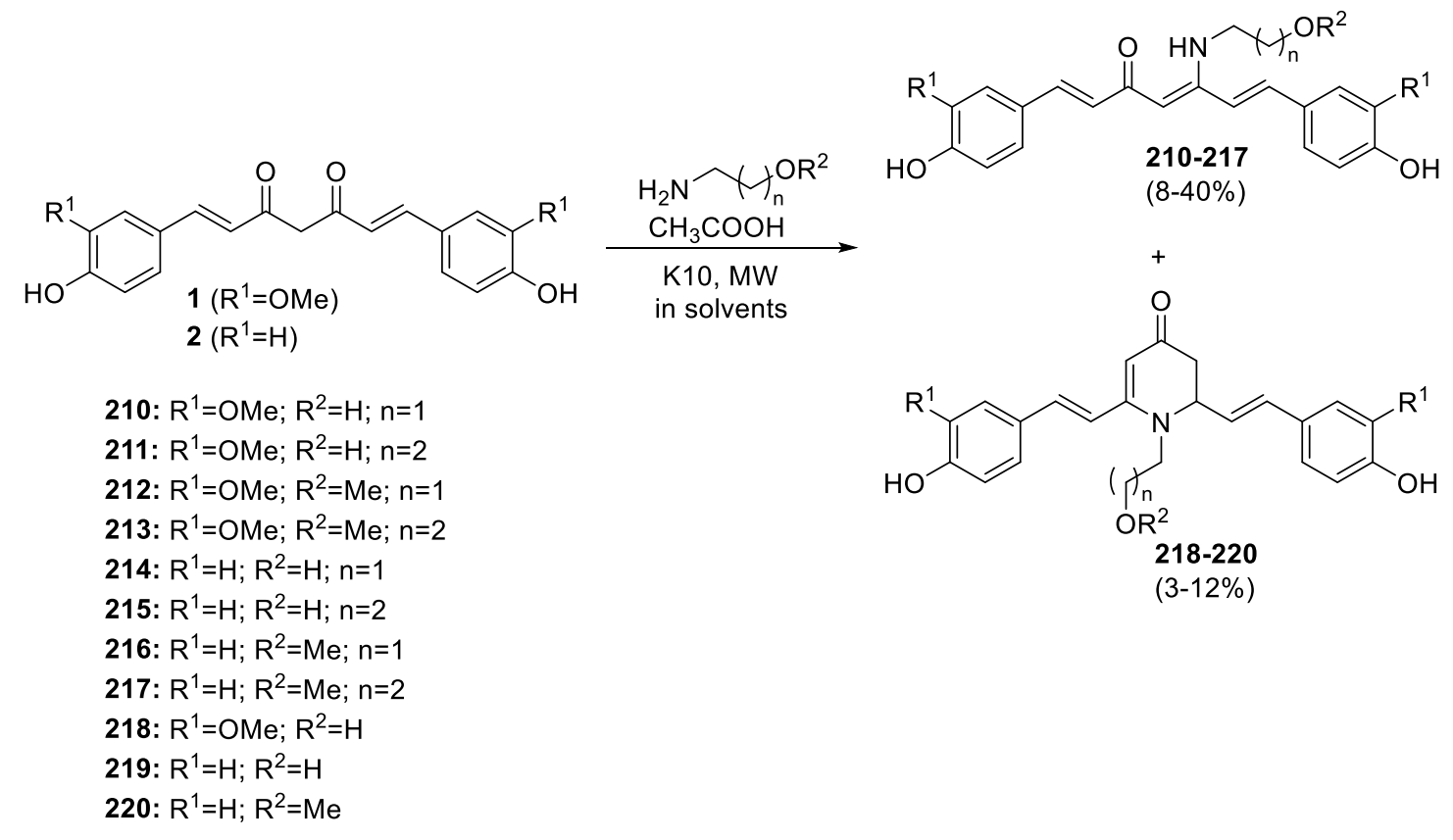

Scheme 14. Synthesis of $\beta$-enaminones 210-220.

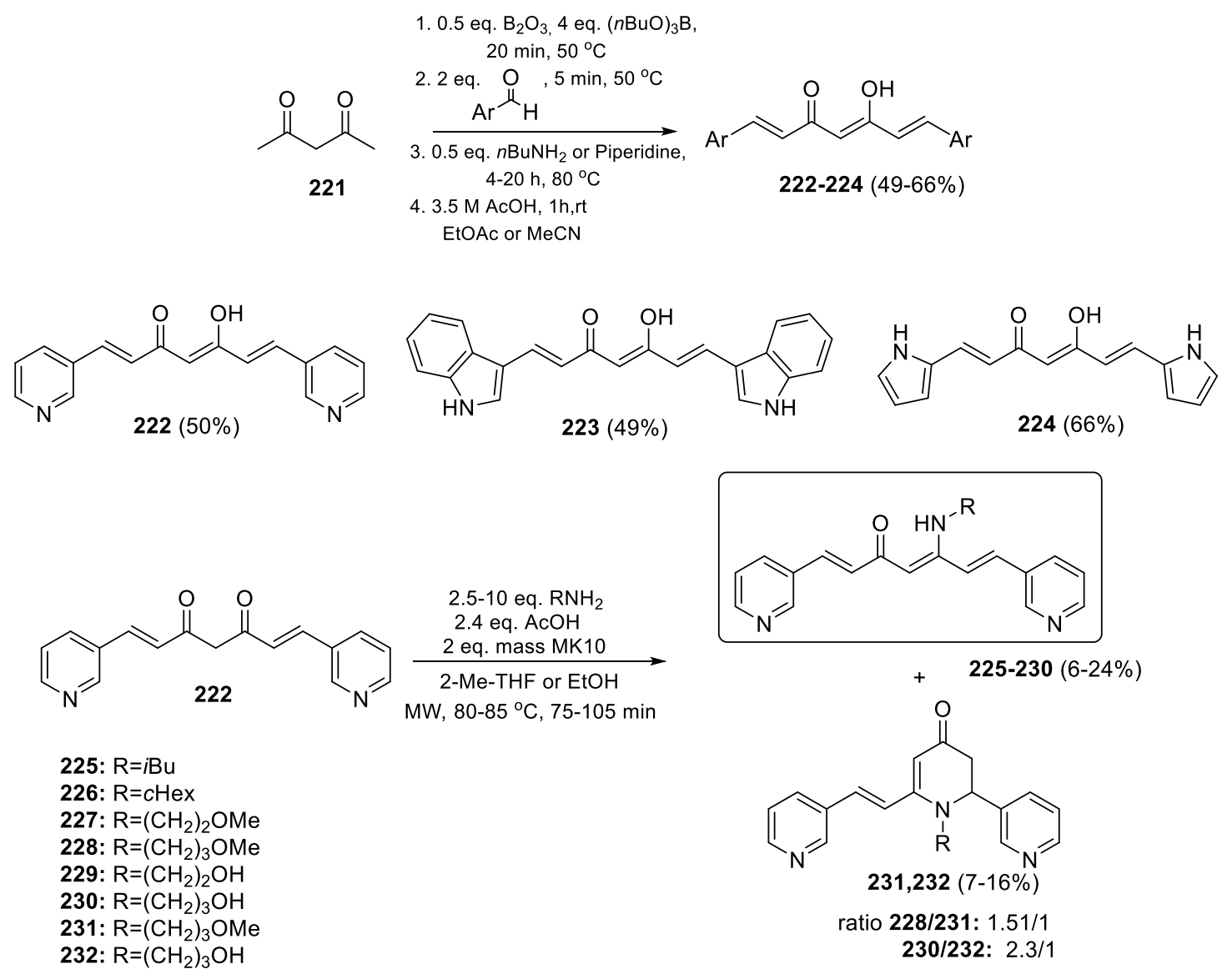

Scheme 15. Synthesis of $\beta$-enaminones 222-232.

Another set of pyridine-, indole- and pyrrole-based curcumin analogs 222-232 was synthesized with the objective of addressing the bioavailability and improvement of biological activity of curcumin (Scheme 15). ${ }^{218}$ 
All of these symmetrical aza-heteroaromatic curcuminoids showed better water solubility profiles in comparison to curcumin and bisdemethoxycurcumin.

A set of non-symmetrical curcuminoids 235-252 (Figure 18) containing both a phenolic group and an azaheteroaromatic scaffold was further prepared in continuation of this work in order to combine good solubility, antioxidant potential and cytotoxic properties in a single molecule (Scheme 16). ${ }^{219} 252$ was synthesized to compare its activity with 247 and 251, which both contain a thiophen-2-yl moiety. All the derivatives displayed a better water solubility than curcumin and higher $\mathrm{IC}_{50}$ values for non-carcinogenic cells than carcinogenic cell lines, implying that they might be less harmful toward healthy cells. The study concluded that the preservation of the 4-hydroxy-3-methoxyphenyl moiety may provide interesting properties when combined with different azaheteroaromatics.

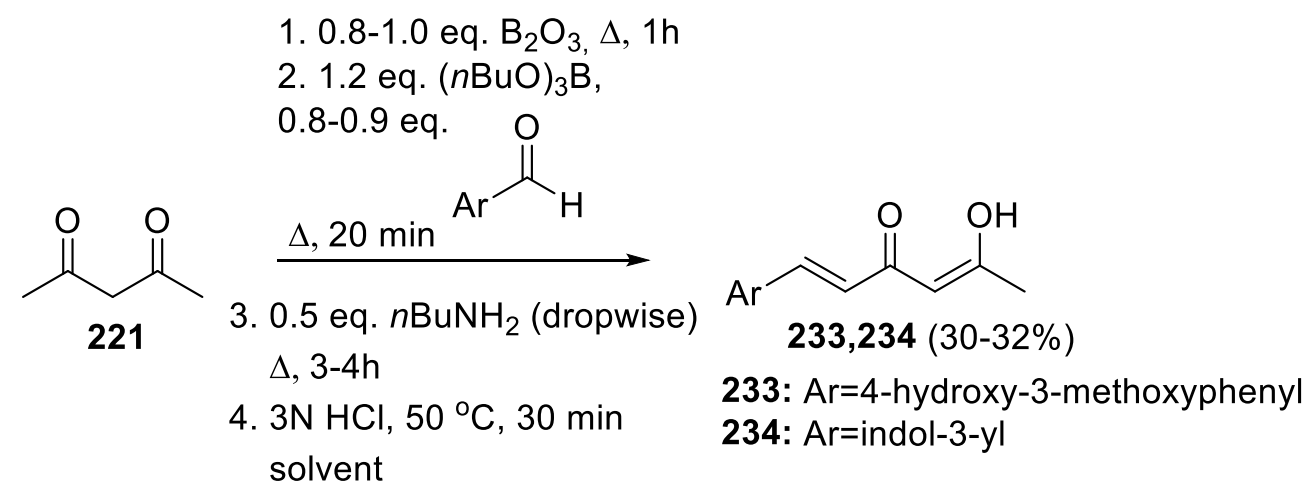

1. $1.0-1.1$ eq. $\mathrm{B}_{2} \mathrm{O}_{3}, \Delta, 1 \mathrm{~h}$

2. $1.2-2.2$ eq. $(n \mathrm{BuO})_{3} \mathrm{~B}$, 1.1-1.5 eq.<smiles>[3H]C=CC(=O)C=C(C)O</smiles><smiles>O=CC(=O)c1ccccc1</smiles>

3. 0.016-0.2 eq. piperidine (dropwise) $\mathrm{Ar}$ $\triangle, 10-180 \mathrm{~min}$ 235-247 (11-69\%)

4. $3 \mathrm{~N} \mathrm{HCl}, 50^{\circ} \mathrm{C}, 30 \mathrm{~min}$ $\mathrm{CH}_{3} \mathrm{CN}$

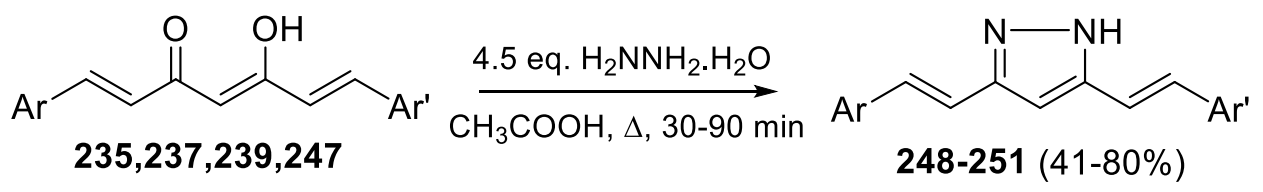

Scheme 16. Synthesis of $\beta$-enaminones 235-251. 
<smiles>COc1cc(/C=C/C(=O)/C=C/C(=O)/C=C(O)/C=C(O)/C=C/c2ccncc2)ccc1O</smiles><smiles>COc1cc(/C=C/C(=O)/C=C(O)/C=C/c2ccccn2)ccc1O</smiles><smiles>COc1cc(/C=C/C(=O)/C=C(O)/C=C/c2cccc3cnccc23)ccc1O</smiles><smiles>COc1cc(/C=C/C(=O)/C=C(O)/C=C/c2ccnc3ccccc23)ccc1O</smiles><smiles>[Z14]C=C(O)/C=C/c1c[nH]c2ccccc12</smiles><smiles>[Z20]C(=O)/C=C(O)/C=C/c1ccc(O)c(OC)c1</smiles><smiles>[Z16]C(/C=C/c1ccncc1)=C\C(=O)/C=C/c1c[nH]c2ccccc12</smiles><smiles></smiles><smiles>[Z20]/C(C=Cc1c[nH]c2ccccc12)=C\C(O)=C\C=C\c1cccnc1</smiles><smiles>[R4][C@@H](/C=C/C(=O)/C=C/c1ccccn1)/C=C/c1c[nH]c2ccccc12</smiles>

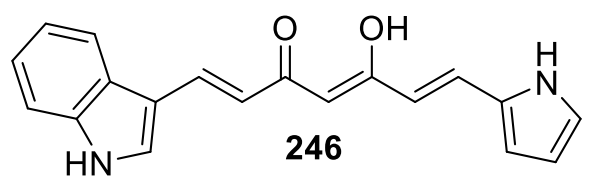<smiles>[Z10]/C=C(O)\C=C\C(=O)/C=C/c1c[nH]c2ccccc12</smiles><smiles></smiles><smiles></smiles><smiles>COc1cc(/C=C/c2cc(/C=C/c3cccs3)[nH]n2)ccc1O</smiles><smiles>COc1cc(/C=C/c2cc(/C=C/c3cccc4cnccc34)[nH]n2)ccc1O</smiles>

Figure 18. Structures of curcuminoids 235-252.

Another small set of monocarbonyl analogs of curcumin 255-260 was also synthesized (Scheme 17) and evaluated for cytotoxicity. In particular, bis-3-methoxy-4-hydroxy- and bis-4-methoxyphenyl-substituted monocarbonyls were synthesized and transformed into three-dimensional $N$-acetylpyrazoline derivatives. ${ }^{220}$ Preliminary cytotoxic evaluation revealed significant effects for 4-hydroxy (pyrazoline) monocarbonyl curcuminoid 257, and non-phenolic variants displayed rather poor activity. 

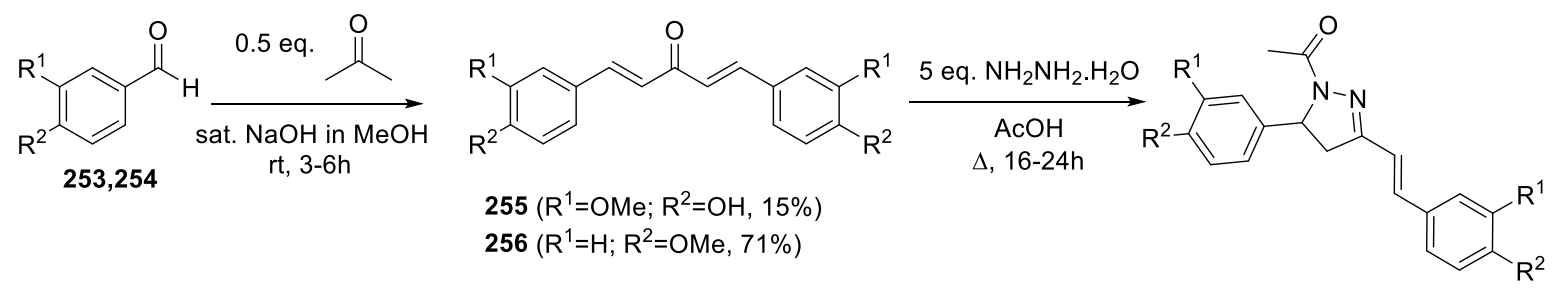

$257\left(R^{1}=\mathrm{OMe} ; \mathrm{R}^{2}=\mathrm{OH}, 40 \%\right)$

$258\left(R^{1}=H ; R^{2}=O M e, 99 \%\right)$

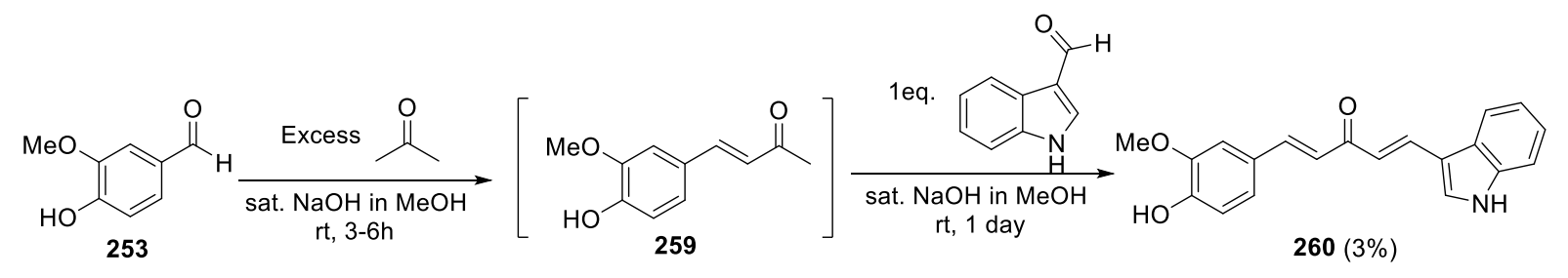

Scheme 17. Synthesis of $\beta$-enaminones 255-260.

Deviating from the classical flat curcuminoid framework, an unexplored modification has been investigated recently, in which novel out-of-plane 1,4-thiazepane-based curcuminoids 264-287 (Figure 19) were prepared (Scheme 18), and the impact of this modification was examined on their biological activity. ${ }^{221}$ Thiazepane analogs 264-278 were generated from starting materials curcumin $\mathbf{1}$ and bisdemethoxycurcumin $\mathbf{2}$ or the pyridin-3-yl analog of curcumin, compounds 281-284 were prepared via $O$-acetylation from derivatives of series 264-278, and unprecedented thiazepine-pyrazoline curcuminoids $\mathbf{2 8 5}$ and $\mathbf{2 8 6}$ were constructed via an extension of enone structural modification of analogs 264 and 272. Arylmethylidene-substituted cyclohexenones $\mathbf{2 7 9}$ and 280, based on substrates indol-3-yl and pyrrol-2-yl curcuminoids, were selectively produced using ethanol as the solvent. Furthermore, fluorophenyl-containing cyclohexanone 287 was synthesized for the first time by changing $n$-butylamine to di-isopropylamine, which stimulated the attack of a second molecule of acetylacetone. The synthesized derivatives 266-268, 272-273, 277-278, 279,285 and 287 displayed a better antiproliferative activity compared to the parent compounds $\mathbf{1}$ and $\mathbf{2}$, and in some cases a better activity than Doxorubicin, an established anticancer drug. The cell protectivity tests were conducted with derivatives 264-265, 269-270, 275-276 and a better cytoprotection than curcumin 1 and a comparable cytoprotective capacity as that of ascorbic acid and Trolox was observed. Because of their three-dimensional architecture, generally culminating in a better druglikeness, and their promising cytotoxic properties, these thiazepane-based curcuminoids can be considered as an innovative scaffold for further elaborations en route to the development of curcumin-based anticancer drugs. 


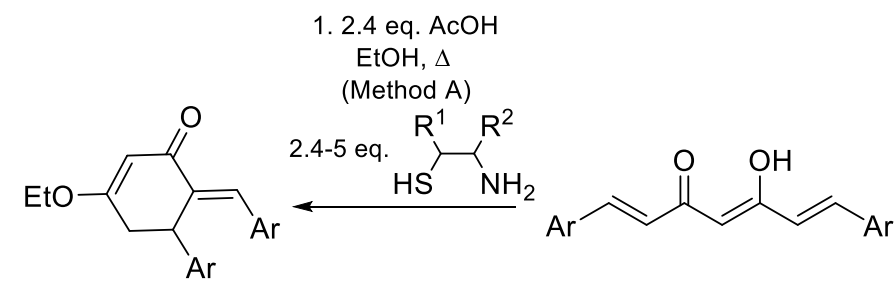

279: Ar=indol-3-yl

280: $\mathrm{Ar}=$ pyrrol-2-yl (16-39\%)

$$
\begin{aligned}
& \text { 1. } 2.4 \text { eq. } \mathrm{AcOH} \\
& \text { EtOH or } \mathrm{MeOH}, \Delta \\
& (\text { Method } \mathrm{A} \text { ) }
\end{aligned}
$$

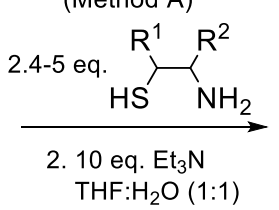

$\Delta($ Method $\mathrm{B})$<smiles>[R2]C1N/C(=C\C(=O)/C=C/[Te])CC([Al])SC1[R]</smiles>

264-278 (19-98\%)

Ar=4-hydroxy-3-methoxyphenyl 4-hydroxyphenyl or pyridin-3-yl

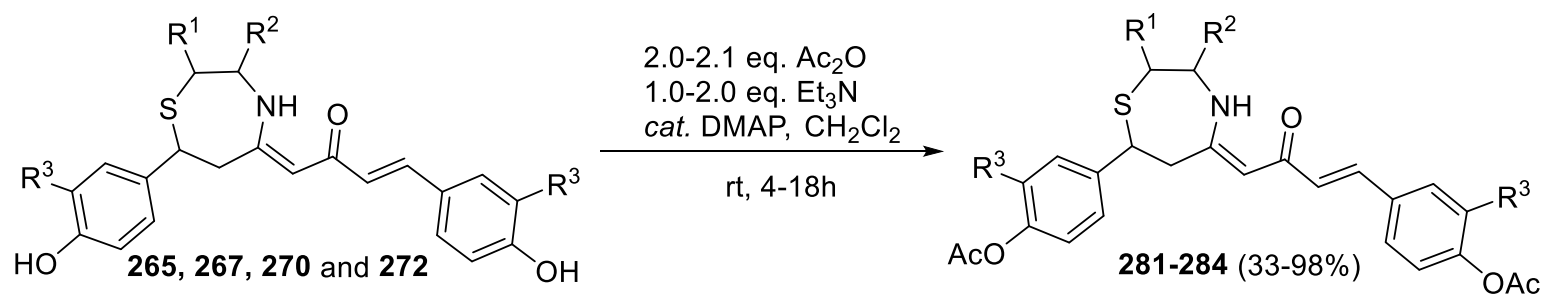<smiles></smiles><smiles>[R]c1cc(/C=C/C(=O)/C=C2/CC(c3ccc(O)c([R])c3)SC([R])C([R])N2)ccc1O</smiles><smiles>[R]C(N)C([R2])S</smiles>

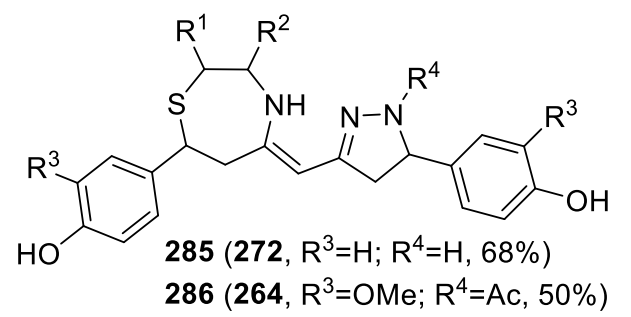<smiles>CC(=O)CC(C)=O</smiles>
221<smiles>CC(C)c1ccc(F)cc1</smiles>

1. $\mathrm{B}_{2} \mathrm{O}_{3}$

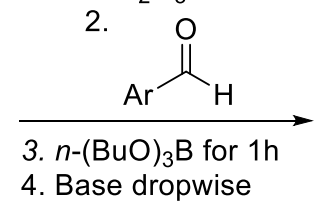<smiles>CC(C)NC(C)C</smiles>

EtOAc, reflux, 24h<smiles>CC(=O)[C@H]1C(C)=C(C(=O)/C=C/c2ccc(F)cc2)C(=O)C[C@H]1c1ccc(F)cc1</smiles>

Scheme 18. Synthesis of curcuminoids 264-287. 

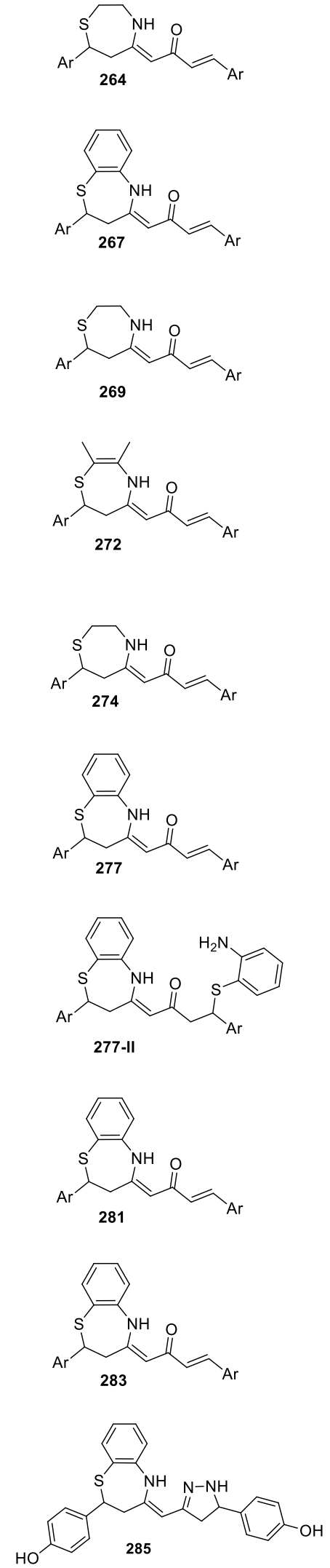
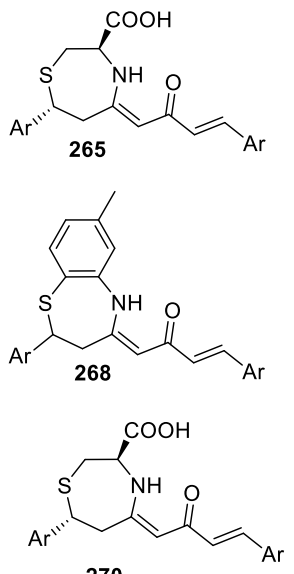

270
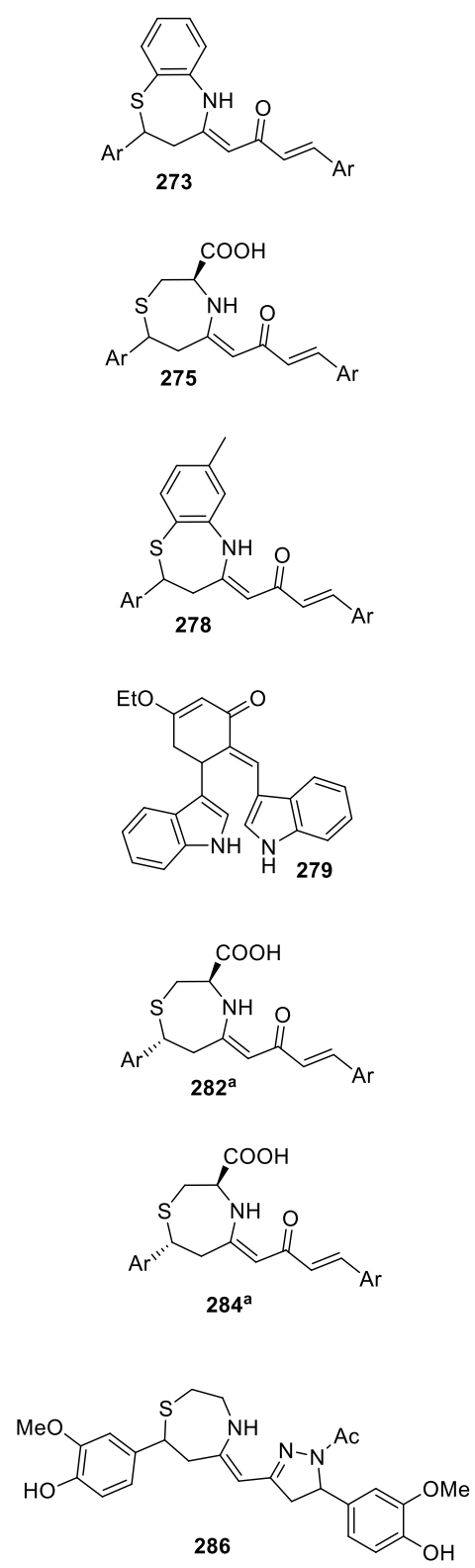
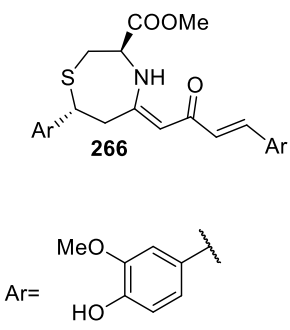

264-268, 286
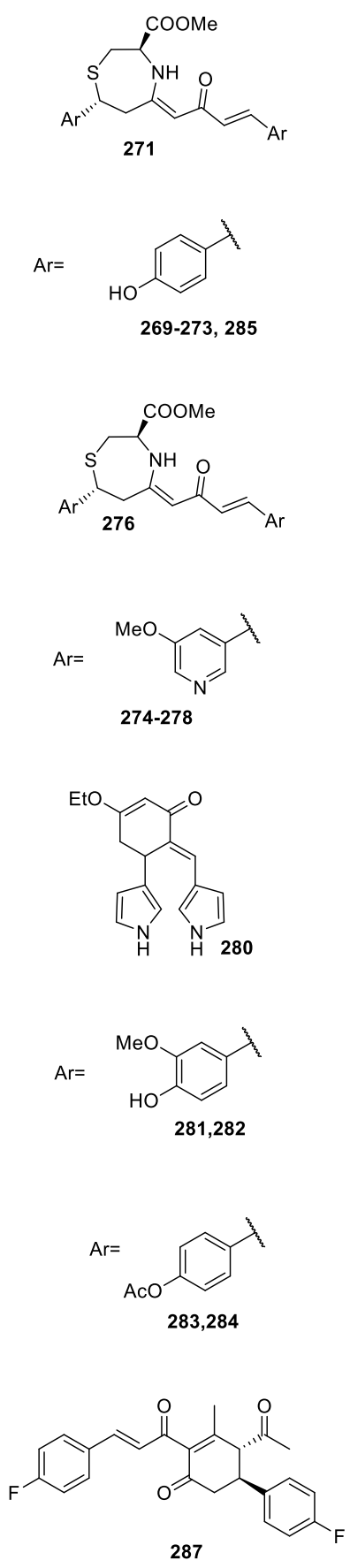

Figure 19. Structures of curcuminoids 264-287. 


\section{Conclusions}

Despite its celebrated pharmacological profile, limitations associated with the natural product curcumin, such as structural instability, low solubility and aspecific activity, have incited medicinal chemists to pursue the construction of new derivatives. In this short literature overview, the synthesis and biological assessment of selected curcumin analogs is discussed, some of them demonstrating superior activities as compared to the parent curcumin scaffold. It is clear that this field has witnessed major efforts related to pyrazole and isoxazole curcuminoid synthesis, culminating in interesting new structures in terms of stability, solubility and/or activity, although it is expected that more innovative approaches will be required to also address the problem of nonspecific biological interactions. In particular, the search for curcuminoids bearing a higher $\mathrm{sp}^{3}$ fraction, exemplified by the recently discovered thiazepane curcuminoid framework, could provide a breath of fresh air in this field by developing stable three-dimensional structures with a better druglike profile, without compromising the pronounced bioactivity of the mother molecule.

\section{Acknowledgements}

The authors are indebted to the Ghent University Special Research Fund (BOF) and to the Erasmus Mundus (LOTUS+) Programme of the European Union for financial support.

\section{References}

1. Shehzad A.; Lee J.; Lee Y. S. BioFactors 2013, 39, 56-68.

https://doi.org/10.1002/biof.1068

2. Shen L. R.; Parnell L. D.; Ordovas J. M.; Lai C. Q. BioFactors 2013, 39, 133-140. https://doi.org/10.1002/biof.1086

3. He Y.; Yue Y.; Zheng X.; Zhang K.; Chen S.; Du Z. Molecules 2015, 20, 9183-9213. https://doi.org/10.3390/molecules20059183

4. Kunnumakkara A. B.; Anand P.; Aggarwal B. B. Cancer lett. 2008, 269, 199-225. https://doi.org/10.1016/i.canlet.2008.03.009

5. Choudhuri T.; Pal S.; Das T.; Sa G. J. Biol. Chem. 2005, 280, 20059-20068. https://doi.org/10.1074/ibc.M410670200

6. Goel A.; Jhurani S.; Aggarwal B. B. Mol. Nutr. Food Res. 2008, 52, 1010-1030. https://doi.org/10.1002/mnfr.200700354

7. Johnson J. J.; Mukhtar H. Cancer lett. 2007, 255, 170-181. https://doi.org/10.1016/j.canlet.2007.03.005

8. Villegas I.; Sanchez-Fidalgo S.; Alarcon de la Lastra C. Mol. Nutr. Food Res. 2008, 52, 1040-1061. https://doi.org/10.1002/mnfr.200700280

9. Aggarwal B. B.; Kumar A.; Bharti A. C. Anticancer Res. 2003, 23, 363-398.

10. Sarkar F. H.; Li Y.; Wang Z.; Padhye S. Curr. Pharm. Des. 2010, 16, 1801-1812. https://doi.org/10.2174/138161210791208956

11. Wang Y. J.; Pan M. H.; Cheng A. L.; Lin L. I.; Ho Y. S.; Hsieh C. Y.; Lin J. K. J. Pharm. Biomed. Anal. 1997, 15, 1867-1876. 
https://doi.org/10.1016/S0731-7085(96)02024-9

12. Anand P.; Kunnumakkara A. B.; Newman R. A.; Aggarwal B. B. Mol. Pharm. 2007, 4, 807-818.

https://doi.org/10.1021/mp700113r

13. Baell J. B.; Holloway G. A. J. Med. Chem. 2010, 53, 2719-2740.

https://doi.org/10.1021/jm901137i

14. Li H.; Zhong C.; Wang Q.; Chen W.; Yuan Y. Antiviral Res. 2019, 167, 98-103.

https://doi.org/10.1016/j.antiviral.2019.04.011

15. Narlawar R.; Pickhardt M.; Leuchtenberger S.; Baumann K.; Krause S.; Dyrks T.; Weggen S.; Mandelkow E.; Schmidt B. ChemMedChem 2008, 3, 165-172.

https://doi.org/10.1002/cmdc.200700218

16. Wang Y.-L.; Huang W.; Chen S.; Chen S.-Q.; Wang S.-F. J. Chin. Pharm. 2011, 20, 235-244.

17. Ahsan N.; Mishra S.; Jain M. K.; Surolia A.; Gupta S. Sci. Rep. 2015, 5, 9862.

https://doi.org/10.1038/srep09862

18. De Vreese R.; Grootaert C.; D’hoore S.; Theppawong A.; Van Damme S.; Van Bogaert M.; Van Camp J.; D’hooghe M. Eur. J. Med. Chem 2016, 123, 727-736.

https://doi.org/10.1016/i.ejmech.2016.07.017

19. Theppawong A.; De Vreese R.; Vannecke L.; Grootaert C.; Van Camp J.; D'hooghe M. Bioorg. Med. Chem. Lett. 2016, 26, 5650-5656.

https://doi.org/10.1016/j.bmcl.2016.10.068

20. Nelson K. M.; Dahlin J. L.; Bisson J.; Graham J.; Pauli G. F.; Walters M. A. J. Med. Chem. 2017, 60, 16201637.

https://doi.org/10.1021/acs.jmedchem.6b00975

21. Kiuchi F.; Goto Y.; Sugimoto N.; Akao N.; Kondo K.; Tsuda Y. Chem. Pharm. Bull. 1993, 41, 1640-1643. https://doi.org/10.1248/cpb.41.1640

22. Shishodia S.; Chaturvedi M. M.; Aggarwal B. B. Curr. Probl. Cancer 2007, 31, 243-305.

https://doi.org/10.1016/i.currproblcancer.2007.04.001

23. Anand P.; Thomas S. G.; Kunnumakkara A. B.; Sundaram C.; Harikumar K. B.; Sung B.; Tharakan S. T.; Misra K.; Priyadarsini I. K.; Rajasekharan K. N.; Aggarwal B. B. Biochem. Pharmacol. 2008, 76, 1590-1611. https://doi.org/10.1016/j.bcp.2008.08.008

24. Govindarajan V. S. Crit. Rev. Food Sci. Nutr. 1980, 12, 199-301.

https://doi.org/10.1080/10408398009527278

25. Ammon H. P.; Wahl M. A. Planta Med. 1991, 57, 1-7.

https://doi.org/10.1055/s-2006-960004

26. Burish T. G.; Jenkins R. A. Health Psychol. Open 1992, 11, 17-23.

https://doi.org/10.1037/0278-6133.11.1.17

27. Lee W. M. N. Engl. J. Med. 1993, 329, 1862-1872.

https://doi.org/10.1056/NEJM199312163292508

28. Lao C. D.; Ruffin M. T. T.; Normolle D.; Heath D. D.; Murray S. I.; Bailey J. M.; Boggs M. E.; Crowell J.; Rock C. L.; Brenner D. E. BMC Complement. Altern. Med. 2006, 6, 10.

https://doi.org/10.1186/1472-6882-6-10

29. Dorai T.; Aggarwal B. B. Cancer Lett. 2004, 215, 129-140.

https://doi.org/10.1016/j.canlet.2004.07.013

30. Payton F.; Sandusky P.; Alworth W. L. J. Nat. Prod. 2007, 70, 143-146.

https://doi.org/10.1021/np060263s 
31. Jagannathan R.; Abraham P. M.; Poddar P. J. Phys. Chem. B 2012, 116, 14533-14540. https://doi.org/10.1021/ip3050516

32. Ghosh M.; Singh A. T. K.; Xu W.; Sulchek T.; Gordon L. I.; Ryan R. O. Nanomedicine 2011, 7, $162-167$. https://doi.org/10.1016/i.nano.2010.08.002

33. Sun M.; Su X.; Ding B.; He X.; Liu X.; Yu A.; Lou H.; Zhai G. Nanomedicine 2012, 7, 1085-1100. https://doi.org/10.2217/nnm.12.80

34. Tamvakopoulos C.; Dimas K.; Sofianos Z.; Hatziantoniou S.; Han Z.; Liu Z.; Wyche J.; Pantazis P. Clin. Cancer Res. 2007, 13, 1269-1277.

https://doi.org/10.1158/1078-0432.CCR-06-1839

35. Robinson T. P.; Hubbard R. B.; Ehlers T. J.; Arbiser J. L.; Goldsmith D. J.; Bowen J. P. Bioorg. Med. Chem. 2005, 13, 4007-4013.

https://doi.org/10.1016/j.bmc.2005.03.054

36. Liang G.; Shao L.; Wang Y.; Zhao C.; Chu Y.; Xiao J.; Zhao Y.; Li X.; Yang S. Bioorg. Med. Chem. 2009, 17, 2623-2631.

https://doi.org/10.1016/i.bmc.2008.10.044

37. Somparn P.; Phisalaphong C.; Nakornchai S.; Unchern S.; Morales N. P. Biol. Pharm. Bull. 2007, 30, 74-78. https://doi.org/10.1248/bpb.30.74

38. Shen L.; Ji H.F. Trends. Mol. Med. 2012, 18, 138-144.

https://doi.org/10.1016/j.molmed.2012.01.004

39. Bisht S.; Feldmann G.; Soni S.; Ravi R.; Karikar C.; Maitra A.; Maitra A. J. Nanobiotechnology 2007, 5, 3. https://doi.org/10.1186/1477-3155-5-3

40. Gupta V.; Aseh A.; Ríos C. N.; Aggarwal B. B.; Mathur A. B. Int. J. Nanomedicine 2009, 4, 115-122. https://doi.org/10.2147/IJN.S5581

41. Prajakta D.; Ratnesh J.; Chandan K.; Suresh S.; Grace S.; Meera V.; Vandana P. J. Biomed. Nanotechnol. 2009, 5, 445-455.

https://doi.org/10.1166/jbn.2009.1038

42. Bisht S.; Mizuma M.; Feldmann G.; Ottenhof N. A.; Hong S.M.; Pramanik D.; Chenna V.; Karikari C.; Sharma R.; Goggins M. G.; Rudek M. A.; Ravi R.; Maitra A.; Maitra A. Mol. Cancer Ther. 2010, 9, 2255 2264.

https://doi.org/10.1158/1535-7163.MCT-10-0172

43. Das R. K.; Kasoju N.; Bora U. Nanomedicine 2010, 6, 153-160. https://doi.org/10.1016/j.nano.2009.05.009

44. Duan J.; Zhang Y.; Han S.; Chen Y.; Li B.; Liao M.; Chen W.; Deng X.; Zhao J.; Huang B. Int. J. Pharm. 2010, 400, 211-220.

https://doi.org/10.1016/j.ijpharm.2010.08.033

45. Mulik R. S.; Mönkkönen J.; Juvonen R. O.; Mahadik K. R.; Paradkar A. R. Int. J. Pharm. 2010, 398, $190-203$. https://doi.org/10.1016/j.ijpharm.2010.07.021

46. Yallapu M. M.; Gupta B. K.; Jaggi M.; Chauhan S. C. J. Colloid Interface Sci. 2010, 351, 19-29. https://doi.org/10.1016/j.jcis.2010.05.022

47. Yallapu M. M.; Maher D. M.; Sundram V.; Bell M. C. Jaggi M.; Chauhan S. C. J. Ovarian Res. 2010, 3, 11. https://doi.org/10.1186/1757-2215-3-11

48. Yen F.-L.; Wu T.-H.; Tzeng C.-W.; Lin L.-T.; Lin C.-C. J. Agric. Food Chem. 2010, 58, 7376-7382. https://doi.org/10.1021/jf100135h

49. Jithan A. V.; Madhavi K.; Madhavi M.; Prabhakar K. Int. J. Pharm. Investig. 2011, 1, 119-125. 
https://doi.org/10.4103/2230-973X.82432

50. Kakkar V.; Singh S.; Singla D.; Kaur I. P. Mol. Nutr. Food Res. 2011, 55, 495-503. https://doi.org/10.1002/mnfr.201000310

51. Kim T. H.; Jiang H. H.; Youn Y. S.; Park C. W.; Tak K. K.; Lee S.; Kim H.; Jon S.; Chen X.; Lee K. C. Int. J. Pharm. 2011, 403, 285-291. https://doi.org/10.1016/j.ijpharm.2010.10.041

52. Sanoj Rejinold N.; Muthunarayanan M.; Divyarani V. V.; Sreerekha P. R.; Chennazhi K. P.; Nair S. V.; Tamura H.; Jayakumar R. J. Colloid Interface Sci. 2011, 360, 39-51.

https://doi.org/10.1016/j.jcis.2011.04.006

53. Dev S.; Prabhakaran P.; Filgueira L.; Iyer K. S.; Raston C. L. Nanoscale 2012, 4, 2575-2579. https://doi.org/10.1039/C2NR11502F

54. Kakran M.; Sahoo N. G.; Tan I.-L.; L. Li J. Nanopart. Res. 2012, 14, 757. https://doi.org/10.1007/s11051-012-0757-0

55. Liu J.; Xu L.; Liu C.; Zhang D.; Wang S.; Deng Z.; Lou W.; Xu H.; Bai Q.; Ma J. Carbohydr. Polym. 2012, 90, 16-22.

https://doi.org/10.1016/i.carbpol.2012.04.036

56. Kazemi-Lomedasht F.; Rami A.; Zarghami N. Adv. Pharm. Bull. 2013, 3, 127-130.

57. Phuong T. H.; Tuan Q. D.; Thu T. M. T.; Hong H. T. T.; Hoai N. N.; Xuan P. N.; Minh N. T. T.; Quoc T. P.; Hong T. P. T.; Kim O. V. T.; Mai H. L. Chem. Lett. 2013, 42, 255-257.

58. Yallapu M. M.; Ebeling M. C.; Jaggi M.; Chauhan S. C. Curr. Drug Metab. 2013, 14, 504-515. https://doi.org/10.2174/1389200211314040012

59. Yen F.-L.; Tsai M.-H.; Yang C.-M.; Liang C.-J.; Lin C.-C.; Chiang Y.-C.; Lee H.-C.; Ko H.-H.; Lee C.-W. PLoS One 2013, 8, e63845.

https://doi.org/10.1371/journal.pone.0063845

60. Ding Q.; Niu T.; Yang Y.; Guo Q.; Luo F.; Qian Z. J. Biomed. Nanotechnol. 2014, 10, 632-641. https://doi.org/10.1166/jbn.2014.1829

61. Zhang J.; Li S.; An F.-F.; Liu J.; Jin S.; Zhang J.-C.; Wang P. C.; Zhang X.; Lee C.-S.; Liang X.-J. Nanoscale 2015, 7, 13503-13510. https://doi.org/10.1039/C5NR03259H

62. Zhao Z.; Xie M.; Li Y.; Chen A.; Li G.; Zhang J.; Hu H.; Wang X.; Li S. Int. J. Nanomedicine 2015, 10, 31713181.

https://doi.org/10.2147/IJN.S80434

63. Shoba G.; Joy D.; Joseph T.; Majeed M.; Rajendran R.; Srinivas P. S. S. R. Planta Med. 1998, 64, 353-356. https://doi.org/10.1055/s-2006-957450

64. Shaikh J.; Ankola D. D.; Beniwal V.; Singh D.; M. N. V. R. Kumar Eur. J. Pharm. Sci. 2009, 37, $223-230$. https://doi.org/10.1016/i.ejps.2009.02.019

65. Sehgal A.; Kumar M.; Jain M.; Dhawan D. K. Food Chem. Toxicol. 2011, 49, 3002-3006. https://doi.org/10.1016/i.fct.2011.07.058

66. Sehgal A.; Kumar M.; Jain M.; Dhawan D. K. Hum. Exp. Toxicol. 2012, 31, 473-482. https://doi.org/10.1177/0960327111421943

67. Rinwa P.; Kumar A. Brain Res. 2012, 1488, 38-50. https://doi.org/10.1016/j.brainres.2012.10.002

68. Ramakrishna Rao R.; Platel K.; Srinivasan K. Food / Nahrung 2003, 47, 408-412. https://doi.org/10.1002/food.200390091 
69. Moorthi C.; Kathiresan K. J. Medical Hypotheses and Ideas 2013, 7, 15-20.

https://doi.org/10.1016/i.jmhi.2012.10.005

70. Kakarala M.; Brenner D. E.; Korkaya H.; Cheng C.; Tazi K.; Ginestier C.; Liu S.; Dontu G.; Wicha M. S. Breast Cancer Res. Tr. 2010, 122, 777-785.

https://doi.org/10.1007/s10549-009-0612-x

71. Gulseren I.; Guri A.; Corredig M. Food Funct. 2014, 5, 1218-1223.

https://doi.org/10.1039/c3fo60554j

72. Bhutani M. K.; Bishnoi M.; Kulkarni S. K. Pharmacol. Biochem. Behav. 2009, 92, 39-43.

https://doi.org/10.1016/j.pbb.2008.10.007

73. Balakrishnan S.; Vellaichamy L.; Menon V. P.; Manoharan S. Toxicol. Mech. Method 2008, 18, 691-696. https://doi.org/10.1080/15376510701781520

74. Anand P.; Sundaram C.; Jhurani S.; Kunnumakkara A. B.; Aggarwal B. B. Cancer Lett. 2008, 267, $133-164$. https://doi.org/10.1016/i.canlet.2008.03.025

75. Shehzad A.; Wahid F.; Lee Y. S. Arch. Pharm. 2010, 343, 489-499.

https://doi.org/10.1002/ardp.200900319

76. Pabon H. J. J. Recl. Trav. Chim. Pays-Bas 1964, 83, 379-386.

https://doi.org/10.1002/recl.19640830407

77. Pedersen U.; Rasmussen P. B.; Lawesson S.-O. Justus Liebigs Ann. Chem. 1985, 1985, 1557-1569.

https://doi.org/10.1002/jlac.198519850805

78. Ahmed M.; Abdul Qadir M.; Imtiaz Shafiq M.; Muddassar M.; Hameed A.; Nadeem Arshad M.; Asiri A. M. Acta Pharm. 2017, 67, 385-395.

https://doi.org/10.1515/acph-2017-0023

79. McGuire S. Adv. Nutr. 2016, 7, 418-419.

https://doi.org/10.3945/an.116.012211

80. Rao D. S.; Sekhara N. C.; Satyanarayana M. N.; Srinivasan M. J. Nutr. 1970, 100, 1307-1315.

https://doi.org/10.1093/in/100.11.1307

81. Patil T. N.; Srinivasan M. Indian J. Exp. Biol. 1971, 9, 167-169.

82. Keshavarz K. Poult. Sci. 1976, 55, 1077-1083.

https://doi.org/10.3382/ps.0551077

83. Hussain M. S.; Chandrasekhara N. Indian J. Med. Res. 1992, 96, 288-291.

84. Soni K. B.; Kuttan R. Indian J. Physiol. Pharmacol. 1992, 36, 273-275.

85. Asai A.; Miyazawa T. J. Nutr. 2001, 131, 2932-2935.

https://doi.org/10.1093/in/131.11.2932

86. Ramirez-Tortosa M. C.; Mesa M. D.; Aguilera M. C.; Quiles J. L.; Baro L.; Ramirez-Tortosa C. L.; Martinez-

Victoria E.; Gil A. Atherosclerosis 1999, 147, 371-378.

https://doi.org/10.1016/S0021-9150(99)00207-5

87. Naidu K. A.; Thippeswamy N. B. Mol. Cell. Biochem. 2002, 229, $19-23$.

https://doi.org/10.1023/A:1017930708099

88. Patro B. S.; Rele S.; Chintalwar G. J.; Chattopadhyay S.; Adhikari S.; Mukherjee T. 2002, 3, 364-370. https://doi.org/10.1002/1439-7633(20020402)3:4<364::AID-CBIC364>3.0.CO;2-S

89. Srivastava R.; Puri V.; Srimal R. C.; Dhawan B. N. Arzneimittel-Forsch. 1986, 36, 715-717.

90. Srivastava K. C.; Bordia A.; Verma S. K. Prostag. Leukotr. Ess. 1995, 52, 223-227. https://doi.org/10.1016/0952-3278(95)90040-3

91. Srivastava R.; Dikshit M.; Srimal R. C.; Dhawan B. N. Thromb. Res. 1985, 40, 413-417. 
https://doi.org/10.1016/0049-3848(85)90276-2

92. Kim D. C.; Ku S. K.; Bae J. S. BMB Rep. 2012, 45, 221-226.

https://doi.org/10.5483/BMBRep.2012.45.4.221

93. Dikshit M.; Rastogi LShukla.; R., Srimal R. C. Indian J. Med. Res. 1995, 101, 31-35.

94. Nirmala C.; Puvanakrishnan R. Mol. Cell. Biochem. 1996, 159, 85-93.

https://doi.org/10.1007/BF00420910

95. Nirmala C.; Puvanakrishnan R. Biochem. Pharmacol. 1996, 51, 47-51.

https://doi.org/10.1016/0006-2952(95)02118-3

96. Venkatesan N. Br. J. Pharmacol. 1998, 124, 425-427.

https://doi.org/10.1038/sj.bjp.0701877

97. Srinivasan M. Indian J. Med. Sci. 1972, 26, 269-270.

https://doi.org/10.1136/jech.26.4.269

98. Babu P. S.; Srinivasan K. Mol. Cell. Biochem. 1995, 152, 13-21.

99. Babu P. S.; Srinivasan K. Mol. Cell. Biochem. 1997, 166, 169-175.

https://doi.org/10.1023/A:1006819605211

100. Suresh Babu P.; Srinivasan K. Mol. Cell. Biochem. 1998, 181, 87-96.

https://doi.org/10.1023/A:1006821828706

101. Arun N.; Nalini N. Plant Foods Hum. Nutr. 2002, 57, 41-52.

https://doi.org/10.1023/A:1013106527829

102. Nishiyama T.; Mae T.; Kishida H.; Tsukagawa M.; Mimaki Y.; Kuroda M.; Sashida Y.; Takahashi K.; Kawada T.; Nakagawa K.; Kitahara M. J. Agric. Food Chem. 2005, 53, 959-963.

https://doi.org/10.1021/if0483873

103. Pari L.; Murugan P.; Ren. Fail. 2007, 29, 881-889.

https://doi.org/10.1080/08860220701540326

104. Chuengsamarn S.; Rattanamongkolgul S.; Luechapudiporn R.; Phisalaphong C.; Jirawatnotai S. Diabetes Care 2012, 35, 2121-2127.

https://doi.org/10.2337/dc12-0116

105. Deodhar S. D.; Sethi R.; Srimal R. C. Indian J. Med. Res. 1980, 71, 632-634.

106. Khanna D.; Sethi G.; Ahn K. S.; Pandey M. K.; Kunnumakkara A. B.; Sung B.; Aggarwal A.; Aggarwal B. B. Curr. Opin. Pharmacol. 2007, 7, 344-351.

https://doi.org/10.1016/j.coph.2007.03.002

107. Banji D.; Pinnapureddy J.; Banji O. J. F.; Kumar A. R.; Reddy K. N. Indian J. Pharm. 2011, 43, 546-550. https://doi.org/10.4103/0253-7613.84970

108. Huang G.; Xu Z.; Huang Y.; Duan X.; Gong W.; Zhang Y.; Fan J.; He F. J. Clin. Immunol. 2013, 33, 550-557. https://doi.org/10.1007/s10875-012-9839-0

109. Daily J. W.; Yang M.; Park S. J. Med. Food 2016, 19, 717-729.

https://doi.org/10.1089/jmf.2016.3705

110. Natarajan C.; Bright J. J. J. Immunol. 2002, 168, 6506-6513. https://doi.org/10.4049/jimmunol.168.12.6506

111. Frautschy S. A.; Hu W.; Kim P.; Miller S. A.; Chu T.; Harris-White M. E.; Cole G. M. Neurobiol. Aging 2001, 22, 993-1005.

https://doi.org/10.1016/S0197-4580(01)00300-1

112. Lim G. P.; Chu T.; Yang F.; Beech W.; Frautschy S. A.; Cole G. M. J. Neurosci. 2001, 21, 8370-8377. https://doi.org/10.1523/JNEUROSCl.21-21-08370.2001 
113. Hamaguchi T.; Ono K.; Yamada M. CNS Neurosci. Ther. 2010, 16, 285-297. https://doi.org/10.1111/j.1755-5949.2010.00147.x

114. Ringman J. M.; Frautschy S. A.; Teng E.; Begum A. N.; Bardens J.; Beigi M.; Gylys K. H.; Badmaev V.; Heath D. D.; Apostolova L. G.; Porter V.; Vanek Z.; Marshall G. A.; Hellemann G.; Sugar C.; Masterman D. L.; Montine T. J.; Cummings J. L.; Cole G. M. Alzheimers Res Ther 2012, 4, 43. https://doi.org/10.1186/alzrt146

115. Tang M.; Taghibiglou C. J. Alzheimers Dis. : JAD 2017, 58, 1003-1016. https://doi.org/10.3233/JAD-170188

116. Li C. J.; Zhang L. J.; Dezube B. J.; Crumpacker C. S.; Pardee A. B. PNAS 1993, 90, 1839-1842. https://doi.org/10.1073/pnas.90.5.1839

117. Sui Z.; Salto R.; Li J.; Craik C.; Ortiz de Montellano P. R. Bioorg. Med. Chem. 1993, 1, 415-422. https://doi.org/10.1016/S0968-0896(00)82152-5

118. Jordan W. C.; Drew C. R. J. Natl. Med. Assoc. 1996, 88, 333.

119. Mazumder A.; Neamati N.; Sunder S.; Schulz J.; Pertz H.; Eich E.; Pommier Y. J. Med. Chem. 1997, 40, 3057-3063.

https://doi.org/10.1021/jm970190x

120. Barthelemy S.; Vergnes L.; Moynier M.; Guyot D.; Labidalle S.; Bahraoui E. Res. Virol. 1998, 149, 43-52. https://doi.org/10.1016/S0923-2516(97)86899-9

121. De Clercq E. Med. Res. Rev. 2000, 20, 323-349. https://doi.org/10.1002/1098-1128(200009)20:5<323::AID-MED1>3.0.CO;2-A

122. Riva D. A.; Fernández-Larrosa P. N.; Dolcini G. L.; Martínez-Peralta L. A.; Coulombié F. C.; Mersich S. E. Arch. Virol. 2008, 153, 561-565.

https://doi.org/10.1007/s00705-007-0023-4

123. Prasad S.; Tyagi A. K. Food Funct 2015, 6, 3412-3419. https://doi.org/10.1039/C5FO00485C

124. Ali A.; Banerjea A. C. Sci. Rep. 2016, 6, 27539. https://doi.org/10.1038/srep27539

125. Sidhu G. S.; Singh A. K.; Thaloor D.; Banaudha K. K.; Patnaik G. K.; Srimal R. C.; Maheshwari R. K. Wound Repair Regen. 1998, 6, 167-177. https://doi.org/10.1046/j.1524-475X.1998.60211.x

126. Sidhu G. S.; Mani H.; Gaddipati J. P.; Singh A. K.; Seth P.; Banaudha K. K.; Patnaik G. K.; Maheshwari R. K. Wound Repair Regen. 1999, 7, 362-374. https://doi.org/10.1046/i.1524-475X.1999.00362.x

127. Phan T. T.; See P.; Lee S. T.; Chan S. Y. J. Trauma 2001, 51, 927-931. https://doi.org/10.1097/00005373-200111000-00017

128. Gopinath D.; Ahmed M. R.; Gomathi K.; Chitra K.; Sehgal P. K.; Jayakumar R. Biomaterials 2004, 25, 19111917.

https://doi.org/10.1016/S0142-9612(03)00625-2

129. Panchatcharam M.; Miriyala S.; Gayathri V. S.; Suguna L. Mol. Cell. Biochem. 2006, 290, 87-96. https://doi.org/10.1007/s11010-006-9170-2

130. Mohanty C.; Sahoo S. K. Drug Discov. Today 2017, 22, 1582-1592. https://doi.org/10.1016/j.drudis.2017.07.001

131. Morikawa T.; Matsuda H.; Ninomiya K.; Yoshikawa M. Biol. Pharm. Bull. 2002, 25, 627-631. https://doi.org/10.1248/bpb.25.627 
132. Nanji A. A.; Jokelainen K.; Tipoe G. L.; Rahemtulla A.; Thomas P.; Dannenberg A. J. Am. J. PhysiolGastrointest. Liver Physiol. 2003, 284, G321-G327.

https://doi.org/10.1152/ajpgi.00230.2002

133. Farombi E. O.; Shrotriya S.; Na H. K.; Kim S. H.; Surh Y. J. Food Chem. Toxicol. 2008, 46, 1279-1287. https://doi.org/10.1016/i.fct.2007.09.095

134. Wu S. J.; Lin Y. H.; Chu C. C.; Tsai Y. H.; Chao J. C. J. Med. Food 2008, 11, 224-229. https://doi.org/10.1089/jmf.2007.555

135. Rivera-Espinoza Y., Muriel P. Liver Int. 2009, 29, 1457-1466. https://doi.org/10.1111/j.1478-3231.2009.02086.x

136. Yun S. S.; Kim S. P.; Kang M. Y.; Nam S. H. Biotechnol. Lett. 2010, 32, 209-214. https://doi.org/10.1007/s10529-009-0153-8

137. Tu C.-T.; Han B.; Yao Q.-Y., Zhang Y.-A.; Liu H.-C.; Zhang S.-C. Int. Immunopharmacol. 2012, 12, $151-157$. https://doi.org/10.1016/j.intimp.2011.11.005

138. Vera-Ramirez L.; Perez-Lopez P.; Varela-Lopez A.; Ramirez-Tortosa M.; Battino M.; Quiles J. L. BioFactors 2013, 39, 88-100.

https://doi.org/10.1002/biof.1057

139. Awasthi S.; Srivatava S. K.; Piper J. T.; Singhal S. S.; Chaubey M.; Awasthi Y. C. Am J. Clin. Nutr. 1996, 64, 761-766.

https://doi.org/10.1093/ajcn/64.5.761

140. Manikandan R.; Thiagarajan R.; Beulaja S.; Chindhu S.; Mariammal K.; Sudhandiran G.; Arumugam M.

Chem. Biol. Interact. 2009, 181, 202-209.

https://doi.org/10.1016/i.cbi.2009.05.011

141. Manikandan R.; Thiagarajan R.; Beulaja S.; Sudhandiran G.; Arumugam M. Free Radic. Biol. Med. 2010, 48, 483-492.

https://doi.org/10.1016/i.freeradbiomed.2009.11.011

142. Saleheen D.; Ali S. A.; Ashfaq K.; Siddiqui A. A.; Agha A.; Yasinzai M. M. Biol. Pharm. Bull. 2002, 25, 386389.

https://doi.org/10.1248/bpb.25.386

143. Chan M. M.; Adapala N. S.; Fong D. Parasitol. Res. 2005, 96, 49-56.

https://doi.org/10.1007/s00436-005-1323-9

144. Adapala N.; Chan M. M. Lab. Invest. 2008, 88, 1329-1339.

https://doi.org/10.1038/labinvest.2008.90

145. Huei-Chen H.; Tong-Rong J.; Sheau-Farn Y. Eur. J. Pharmacol. 1992, 221, 381-384. https://doi.org/10.1016/0014-2999(92)90727-L

146. Chen H.-W.; Huang H.-C. Br. J. Pharmacol. 1998, 124, 1029-1040. https://doi.org/10.1038/sj.bjp.0701914

147. Sahebkar A. Nat. Prod. Res. 2015, 29, 491-492.

https://doi.org/10.1080/14786419.2014.956212

148. Carroll R. E.; Benya R. V.; Turgeon D. K.; Vareed S.; Neuman M.; Rodriguez L.; Kakarala M.; Carpenter P. M.; McLaren C.; Meyskens Jr F. L.; Brenner D. E. Cancer Prev. Res. 2011, 4, 354-364.

https://doi.org/10.1158/1940-6207.CAPR-10-0098

149. He Z.-Y.; Shi C.-B.; Wen H.; Li F.-L.; Wang B.-L.; Wang J. Cancer Invest. 2011, 29, 208-213. https://doi.org/10.3109/07357907.2010.550592

150. Durgaprasad S.; Pai C.G.; Vasanthkumar; Alvres J.F.; Namitha S. Indian J. Med. Res. 2005, 122, 315-318. 
151. Gupta S. C.; Kismali G.; Aggarwal B. B. BioFactors 2013, 39, 2-13. https://doi.org/10.1002/biof.1079

152. Ide H.; Tokiwa S.; Sakamaki K.; Nishio K.; Isotani S.; Muto S.; Hama T.; Masuda H.; Horie S. The Prostate 2010, 70, 1127-1133.

https://doi.org/10.1002/biof.1079

153. Sharma R. A.; Gescher A. J.; Steward W. P. Eur. J. Cancer 2005, 41, 1955-1968. https://doi.org/10.1016/j.ejca.2005.05.009

154. Goel A.; Kunnumakkara A. B.; Aggarwal B. B. Biochem. Pharmacol. 2008, 75, 787-809. https://doi.org/10.1016/j.bcp.2007.08.016

155. Aggarwal B. B.; Sung B. Trends Pharmacol. Sci. 2009, 30, 85-94. https://doi.org/10.1016/j.tips.2008.11.002

156. Prasad S.; Tyagi A. K.; Aggarwal B. B. Cancer Res. Treat. 2014, 46, 2-18. https://doi.org/10.4143/crt.2014.46.1.2

157. Ireson C. R.; Jones D. J.; Orr S.; Coughtrie M. W.; Boocock D. J.; Williams M. L.; Farmer P. B.; Steward W. P.; Gescher A. J. Cancer Epidemiol Biomarkers Prev 2002, 11, 105-111.

158. Garcea G.; Berry D. P.; Jones D. J.; Singh R.; Dennison A. R.; Farmer P. B.; Sharma R. A.; Steward W. P.; Gescher A. J. Cancer Epidemiol Biomarkers Prev 2005, 14, 120-125.

159. Pendleton E.G.; Jamasbi R.J.; Geusz M.E. Anticancer Agents Med Chem 2019, 19, 1012-1020. https://doi.org/10.2174/1871520619666190116141448

160. Lai C.-S.; Ho C.-T.; Pan M.-H. Biomolecules 2020, 10, 831. https://doi.org/10.3390/biom10060831

161. Sasaki H.; Sunagawa Y.; Takahashi K.; Imaizumi A.; Fukuda H.; Hashimoto T.; Wada H.; Katanasaka Y.; Kakeya H.; Fujita M.; Hasegawa K.; Morimoto T. Biol. Pharm. Bull. 2011, 34, 660-665. https://doi.org/10.1248/bpb.34.660

162. Burgos-Moron E.; Calderon-Montano J. M.; Salvador J.; Robles A.; Lopez-Lazaro M. Int. J. Cancer 2010, 126, 1771-1775.

163. Pan M. H.; Huang T. M.; Lin J. K. Drug Metab. Dispos. 1999, 27, 486-494.

164. Hoehle S. I.; Pfeiffer E.; Sólyom A. M.; Metzler M. J. Agric. Food Chem. 2006, 54, 756-764. https://doi.org/10.1021/jf058146a

165. Dempe J. S.; Scheerle R. K.; Pfeiffer E.; Metzler M. Mol. Nutr. Food Res. 2013, 57, 1543-1549. https://doi.org/10.1002/mnfr.201200113

166. Swanson H. I. Drug Metab. Dispos. 2015, 43, 1499-1504.

https://doi.org/10.1124/dmd.115.065714

167. An C.-Y.; Sun Z.-Z.; Shen L.; Ji H.-F. Food Nutr. Res. 2017, 61, 1412814. https://doi.org/10.1080/16546628.2017.1412814

168. Burapan S.; Kim M.; Han J. J. Agric. Food Chem. 2017, 65, 3305-3310. https://doi.org/10.1021/acs.jafc.7b00943

169. Frank J.; Schiborr C.; Kocher A.; Meins J.; Behnam D.; Schubert-Zsilavecz M.; Abdel-Tawab M. Plant Foods Hum. Nutr. 2017, 72, 48-53.

https://doi.org/10.1007/s11130-016-0587-9

170. Peterson C. T.; Vaughn A. R.; Sharma V.; Chopra D.; Mills P. J.; Peterson S. N.; Sivamani R. K. J. Evid.-Based Integr. Med. 2018, 23, 1-8. https://doi.org/10.1177/2515690X18790725 
171. Tranchida F.; Rakotoniaina Z.; Shintu L.; Tchiakpe L.; Deyris V.; Yemloul M.; Stocker P.; Vidal N.; Rimet O.; Hiol A.; Caldarelli S. Sci. Rep. 2017, 7, 5880-5880.

https://doi.org/10.1038/s41598-017-06220-0

172. Farzaei M. H.; Zobeiri M.; Parvizi F.; El-Senduny F. F.; Marmouzi I.; Coy-Barrera E.; Naseri R.; Nabavi S. M.; Rahimi R.; Abdollahi M. Nutrients 2018, 10, 855.

https://doi.org/10.3390/nu10070855

173. Toden S.; Goel A. J. Restor. Med. 2017, 6, 27-36.

https://doi.org/10.14200/jrm.2017.6.0101

174. Nurfina A. N.; Reksohadiprodjo M. S.; Timmerman H.; Jenie U. A.; Sugiyanto D.; van der Goot H. Eur. J. Med. Chem. 1997, 32, 321-328.

https://doi.org/10.1016/S0223-5234(97)89084-8

175. Sardjiman S. S.; Reksohadiprodjo M. S.; Hakim L.; Van Der Goot H.; Timmerman H. Eur. J. Med. Chem. 1997, 32, 625-630.

https://doi.org/10.1016/S0223-5234(97)83288-6

176. Venkatesan P.; Rao M. N. A. J. Pharm. Pharmacol. 2000, 52, 1123-1128.

https://doi.org/10.1211/0022357001774886

177. Hahm E. R.; Cheon G.; Lee J.; Kim B.; Park C.; Yang C. H. Cancer Lett 2002, 184, 89-96.

https://doi.org/10.1016/S0304-3835(02)00170-2

178. Ishida J.; Ohtsu H.; Tachibana Y.; Nakanishi Y.; Bastow K. F.; Nagai M.; Wang H.-K.; Itokawa H.; Lee K.-H. Bioorg. Med. Chem. 2002, 10, 3481-3487.

https://doi.org/10.1016/S0968-0896(02)00249-3

179. Ohtsu H.; Xiao Z.; Ishida J.; Nagai M.; Wang H.; Itokawa H.; Su C.; Shih C.; Chiang T.; Chang E. J. Med.

Chem. 2002, 45, 5037-5042.

https://doi.org/10.1021/im020200g

180. Srivivasan A.; Menon V. P.; Periaswamy V.; Rajasekaran K. N. J. Pharm. Pharm. Sci. 2003, 6, 327-333.

181. Hahm E. R.; Gho Y. S.; Park S.; Park C.; Kim K. W.; Yang C. H. Biochem. Biophys. Res. Commun. 2004, 321, 337-344.

https://doi.org/10.1016/j.bbrc.2004.06.119

182. Ligeret H.; Barthelemy S.; Bouchard Doulakas G.; Carrupt P. A.; Tillement J. P.; Labidalle S.; Morin D. FEBS Lett. 2004, 569, 37-42.

https://doi.org/10.1016/j.febslet.2004.05.032

183. Rukkumani R.; Aruna K.; Varma P. S.; Rajasekaran K. N.; Menon V. P. J. Pharm. Pharm. Sci. 2004, 7, 274283.

https://doi.org/10.1089/imf.2004.7.456

184. Weber W. M.; Hunsaker L. A.; Abcouwer S. F.; Deck L. M.; Vander Jagt D. L. Bioorg. Med. Chem. 2005, 13, 3811-3820.

https://doi.org/10.1016/j.bmc.2005.03.035

185. Chen W.-F.; Deng S.-L.; Zhou B.; Yang L.; Liu Z.-L. Free Radic. Biol. Med. 2006, 40, 526-535. https://doi.org/10.1016/j.freeradbiomed.2005.09.008

186. Jankun J.; Aleem A. M.; Malgorzewicz S.; Szkudlarek M.; Zavodszky M. I.; Dewitt D. L.; Feig M.; Selman S. H.; Skrzypczak-Jankun E. Mol. Cancer Ther. 2006, 5, 1371-1382.

https://doi.org/10.1158/1535-7163.MCT-06-0021

187. Lin L.; Shi Q.; Nyarko A. K.; Bastow K. F.; Wu C.-C.; Su C.-Y.; Shih C. C. Y.; K.-H. Lee J. Med. Chem. 2006, 49, 3963-3972. 
https://doi.org/10.1021/jm051043z

188. Weber W. M.; Hunsaker L. A.; Gonzales A. M.; Heynekamp J. J.; Orlando R. A.; Deck L. M.; Vander Jagt D. L. Biochem. Pharmacol. 2006, 72, 928-940. https://doi.org/10.1016/i.bcp.2006.07.007

189. Weber W. M.; Hunsaker L. A.; Roybal C. N.; Bobrovnikova-Marjon E. V.; Abcouwer S. F.; Royer R. E.; Deck L. M.; Vander Jagt D. L. Bioorg. Med. Chem. 2006, 14, 2450-2461. https://doi.org/10.1016/j.bmc.2005.11.035

190. Wei Q. Y.; Chen W. F.; Zhou B.; Yang L.; Liu Z. L. Biochim. Biophys. Acta 2006, 1760, 70-77. https://doi.org/10.1016/j.bbagen.2005.09.008

191. Costi, R.; Di Santo R.; Artico M.; Miele G.; Valentini P.; Novellino E.; Cereseto A. J. Med. Chem. 2007, 50, 1973-1977.

https://doi.org/10.1021/jm060943s

192. Handler N.; Jaeger W.; Puschacher H.; Leisser K.; Erker T. Chem. Pharm. Bull. 2007, 55, 64-71. https://doi.org/10.1248/cpb.55.64

193. Nichols C.E.; Youssef D.; Harris R.G.; Jha A. Arkivoc 2006, 13, 64-72. https://doi.org/10.3998/ark.5550190.0007.d07

194. Youssef D.; Nichols C.; Cameron T.; Balzarini J.; De Clercq E.; Jha A. Bioorg. Med. Chem. Lett. 2007, 17, 5624-5629.

https://doi.org/10.1016/j.bmcl.2007.07.079

195. Ding L.; Ma S.; Lou H.; Sun L.; Ji M. Molecules 2015, 20, 21501-21514. https://doi.org/10.3390/molecules201219772

196. Wang J.; Xiong T.; Zhou J.; He H.; Wu D.; Du X.; Li X.; Xu B. Nano Res. 2018, 11, 3453-3461. https://doi.org/10.1007/s12274-018-1994-z

197. Deng S.-L.; Chen W.-F.; Zhou B.; Yang L.; Liu Z.-L. Food Chem. 2006, 98, 112-119. https://doi.org/10.1016/i.foodchem.2005.05.063

198. Zhang Q.; Fu Y.; Wang H. W.; Gong T.; Qin Y.; Zhang Z. R. Chin. Chem. Lett. 2008, 19, 281-285. https://doi.org/10.1016/j.cclet.2007.12.035

199. Bairwa K.; Grover J.; Kania M.; Jachak S. M. RSC Adv. 2014, 4, 13946-13978. https://doi.org/10.1039/c4ra00227j

200. Mishra S.; Patel S.; Halpani C.G. Chem. Biodiversity 2019, 16, e1800366 and references cited therein.

201. Amolins M. W.; Peterson L. B.; Blagg B. S. Bioorg. Med. Chem. 2009, 17, 360-367. https://doi.org/10.1016/j.bmc.2008.10.057

202. Mishra S.; Karmodiya K.; Surolia N.; Surolia A. Bioorg. Med. Chem. 2008, 16, 2894-2902. https://doi.org/10.1016/j.bmc.2007.12.054

203. Mayadevi M.; Sherin D. R.; Keerthi V. S.; Rajasekharan K. N.; Omkumar R. V. Bioorg. Med. Chem. 2012, 20, 6040-6047.

https://doi.org/10.1016/j.bmc.2012.08.029

204. Simoni D.; Rizzi M.; Rondanin R.; Baruchello R.; Marchetti P.; Invidiata F. P.; Labbozzetta M.; Poma P.; Carina V.; Notarbartolo M.; Alaimo A.; D'Alessandro N. Bioorg. Med. Chem. Lett. 2008, 18, 845-849. https://doi.org/10.1016/j.bmcl.2007.11.021

205. Qiu P.; Xu L.; Gao L.; Zhang M.; Wang S.; Tong S.; Sun Y.; Zhang L.; Jiang T. Bioorg. Med. Chem. 2013, 21, 5012-5020. https://doi.org/10.1016/j.bmc.2013.06.053

206. Lal J.; Gupta S. K.; Thavaselvam D.; Agarwal D. D. Eur. J. Med. Chem. 2013, 64, 579-588. 
https://doi.org/10.1016/i.ejmech.2013.03.012

207. Shetty S.; Kim Y. J.; Shim H.; Snyder J. P. Molecules 2015, 20, 249-292 and references cited therein. https://doi.org/10.3390/molecules20010249

208. Yin S.; Zheng X.; Yao X.; Wang Y.; Liao D. J. Cancer Ther. 2013, 4, 113-123. https://doi.org/10.4236/jct.2013.41016

209. Zhao C.; Liu Z.; Liang G. Curr. Pharm. Des. 2013, 19, 2114-2135. https://doi.org/10.2174/1381612811319110012

210. Adams B. K.; Cai J.; Armstrong J.; Herold M.; Lu Y. J.; Sun A.; Snyder J. P.; Liotta D. C.; Jones D. P.; Shoji M. Anticancer drugs 2005, 16, 263-275.

https://doi.org/10.1097/00001813-200503000-00005

211. Thomas S. L.; Zhong D.; Zhou W.; Malik S.; Liotta D.; Snyder J. P.; Hamel E.; Giannakakou P. Cell Cycle 2008, 7, 2409-2417. https://doi.org/10.4161/cc.6410

212. Tan X.; Sidell N.; Mancini A.; Huang R. P.; Shenming W.; Horowitz I. R.; Liotta D. C.; Taylor R. N.; Wieser F. Reprod. Sci. 2010, 17, 931-940.

https://doi.org/10.1177/1933719110374239

213. He G.; Feng C.; Vinothkumar R.; Chen W.; Dai X.; Chen X.; Ye Q.; Qiu C.; Zhou H.; Wang Y.; Liang G.; Xie Y.; Wu W. Cancer Chemoth. Pharm. 2016, 78, 1151-1161.

https://doi.org/10.1007/s00280-016-3172-x

214. Bertazza L.; Sensi F.; Cavedon E.; Watutantrige-Fernando S.; Censi S.; Manso J.; Vianello F.; Casal Ide E.; lacobone M.; Pezzani R.; Mian C.; Barollo S. Endocrinology 2018, 159, 2348-2360. https://doi.org/10.1210/en.2018-00124

215. Adams B. K.; Ferstl E. M.; Davis M. C.; Herold M.; Kurtkaya S.; Camalier R. F.; Hollingshead M. G.; Kaur G.; Sausville E. A.; Rickles F. R.; Snyder J. P.; Liotta D. C.; Shoji M. Bioorg. Med. Chem. 2004, 12, 3871-3883. https://doi.org/10.1016/j.bmc.2004.05.006

216. Lagisetty P.; Vilekar P.; Sahoo K.; Anant S.; Awasthi V. Bioorg. Med. Chem. 2010, 18, 6109-6120. https://doi.org/10.1016/j.bmc.2010.06.055

217. Dewitte G.; Walmagh M.; Diricks M.; Lepak A.; Gutmann A.; Nidetzky B.; Desmet T. J. Biotechnol. 2016, 233, 49-55.

https://doi.org/10.1016/j.jbiotec.2016.06.034

218. Theppawong A.; Van de Walle T.; Grootaert C.; Bultinck M.; Desmet T.; Van Camp J.; D’hooghe M. ChemistryOpen 2018, 7, 381-392.

https://doi.org/10.1002/open.201800029

219. Theppawong A.; Van de Walle T.; Grootaert C.; Van Hecke K.; Catry N.; Desmet T.; Van Camp J.; D’hooghe M. ChemistryOpen 2019, 8, 236-247. https://doi.org/10.1002/open.201800287

220. Van de Walle T.; Theppawong A.; Grootaert C.; De Jonghe S.; Persoons L.; Daelemans D.; Van Hecke K.; Van Camp J.; D’hooghe M. Montash. Chem. 2019, 150, 2045-2051. https://doi.org/10.1007/s00706-019-02516-1

221. Theppawong A.; Van de Walle T.; Van Hecke K.; Grootaert C.; Van Camp J.; D’hooghe M. Chem. Eur. J. 2019, 25, 12583-12600.

https://doi.org/10.1002/chem.201902549 


\section{Authors' Biographies}

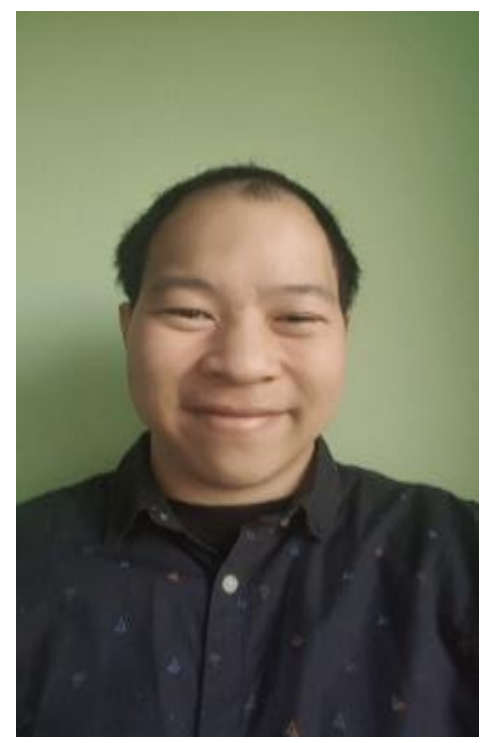

Atiruj Theppawong was born in Chiang Mai, Thailand in 1989. He obtained his Bachelor's degree (Hon.) in Biochemistry and Biotechnology at Chiang Mai University, Thailand and Master's degree in Chemical Biology from Chulabhorn Graduate Insititute, Thailand. He started his PhD under the supervision of Prof. Matthias D'hooghe at the SynBioC Research Group (Department of Green Chemistry and Technology, Faculty of Bioscience Engineering, Ghent University) in 2015, in collaboration with the group of Prof. John Van Camp. He obtained his PhD degree in Applied Biological Sciences: Chemistry and Bioprocess Technology in 2019 with research work mainly focused on synthesis of curcuminoid analogs and their anticancer evaluation.

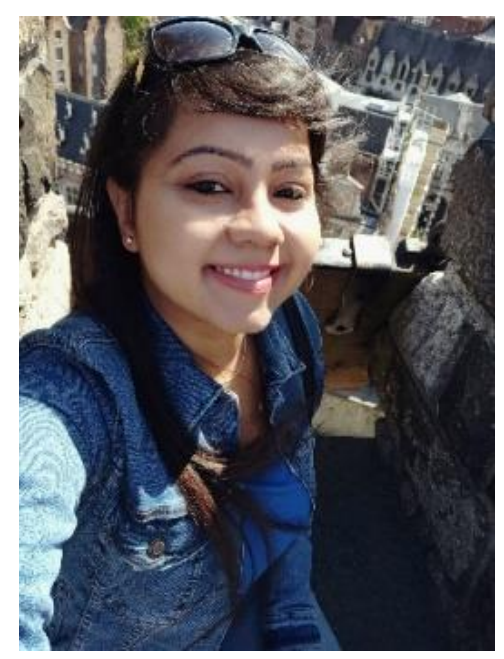

Gurkirat Kaur was born in Abohar, Punjab, India in 1996. She received her diploma for B.Sc.(HS)-Chemistry and M.Sc.(HS)-Chemistry, both from Guru Nanak Dev University, Amritsar, Punjab, India in 2016 and 2018 respectively. She is currently pursuing a sandwich PhD at the SynBioC Research Group, Department of Green Chemistry and Technology (Faculty of Bioscience Engineering, Ghent University) with Prof. Matthias D'hooghe as the promoter and Prof. Vipan Kumar as the co-promoter. The major component of her research interest comprises of the synthesis of $\beta$-lactam based bioactive compounds. 


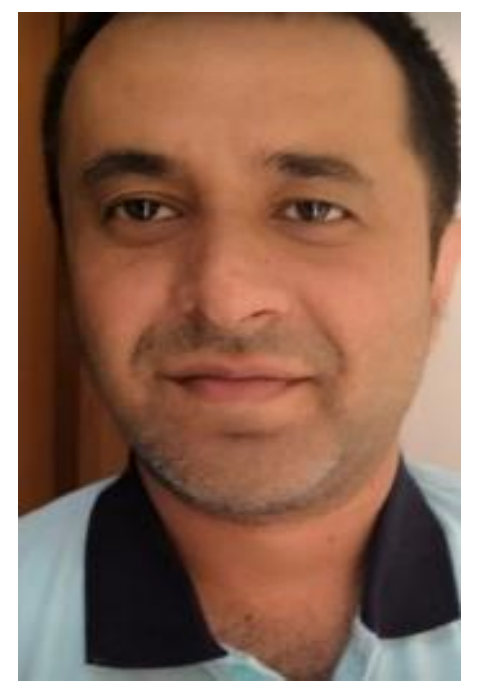

Vipan Kumar is presently working as an Assistant Professor in the Department of Chemistry, Guru Nanak Dev University, Amritsar. He obtained his PhD with Prof. Mohinder P Mahajan, in the Department of Applied Chemistry, GNDU. In 2007, he moved to the University of Cape Town (UCT), South Africa, to pursue his postdoctoral studies with Prof. Kelly Chibale. In 2015, he was awarded a research fellowship from Carl Tryggers research foundation, Sweden, to carry out research at University of Umea, Sweden. His research interests include the development of diverse synthetic protocols for synthesis of novel molecular frameworks targeting tropical infections. Dr. Kumar is author of $>110$ publications in international journals with an $\mathrm{H}$-index of 28.

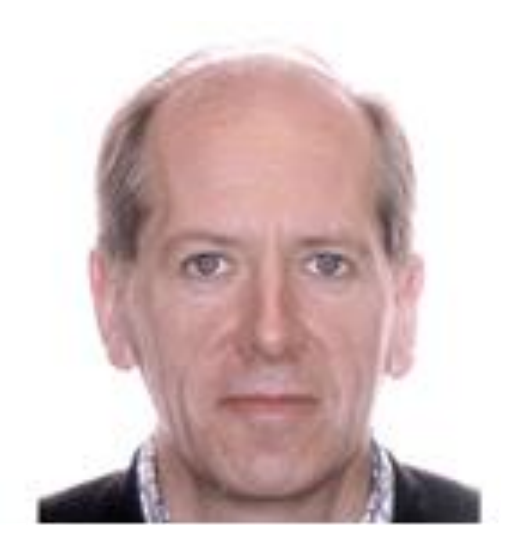

John Van Camp was born in Deurne, Belgium, in 1965. He received his Master's diploma in 1989 (Master of Science in Bioscience Engineering: Chemistry) and his PhD degree in 1996 (Doctor in Applied Biological Sciences: Chemistry), both from Ghent University, Belgium, with Prof. A. Huyghebaert as promoter. In 1996, he became post-doctoral assistant at the Department of Food Technology, Safety and Health, Ghent University, and in 1997-1998 he performed a postdoctoral stay of 6 months at the "Bundesanstalt für Milchforschung, Institut für Physiologie und Biochemie der Ernährung", Kiel, Germany, where he worked on endothelial cell culture models. In October 2001, he was promoted to Associate Professor at the Department of Food technology, Safety and Health (Faculty of Bioscience Engineering, Ghent University), and where he was promoted to full Professor in 2014. He has a main interest in designing advanced cell (co-)culture models to study bioavailability and bioactivity of nutrients and bioactive components in the context of cardiovascular diseases, satiety, and cancer (https://www.ugent.be/bw/foodscience/en/research). As bioactive food expert, PI Van Camp has over 210 A1-publications (H-index 43). He was participant in the European Nutrition Leadership Programme (ENLP) in human nutrition science in Europe. June, 15th-21st, 2000, in Luxembourg, 
NZO-VLAG visiting Professor 2006 at Wageningen University (September, 26-29th, 2006), and FRANCQUI National chair holder 2015-2016 at UCL (Université Catholique De Louvain, Faculté des Bioingénieurs). He is (co-) promotor of 26 PhD's at the Faculty of Bioscience Engineering, Ghent University, and one of the organizers of the 2nd Food Chemistry Conference in Seville (E), 17 September - 19 September 2019.

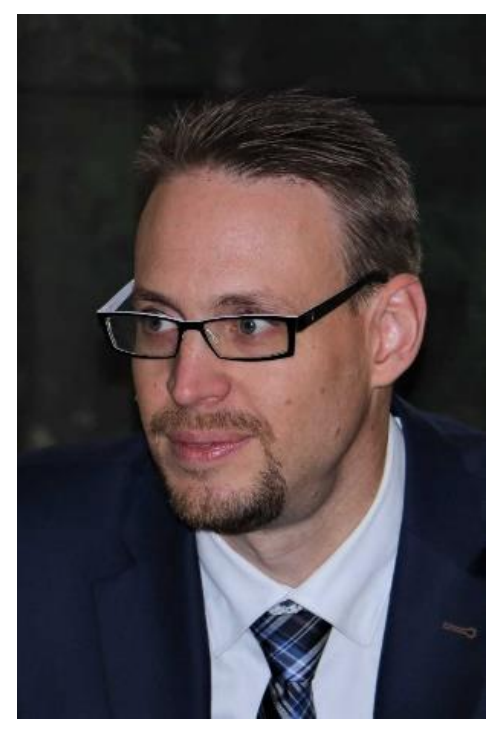

Matthias D'hooghe was born in Kortrijk, Belgium, in 1978. He received his Master's diploma in 2001 (Master of Science in Bioscience Engineering: Chemistry) and his PhD degree in 2006 (Doctor in Applied Biological Sciences: Chemistry), both from Ghent University, Belgium, with Prof. N. De Kimpe as promoter. In 2007, he became postdoctoral assistant at the Department of Green Chemistry and Technology, Ghent University, and in 2009 he performed a short postdoctoral stay with Prof. D. Vogt at Eindhoven University of Technology (The Netherlands) in the field of homogeneous catalysis. In October 2010, he was promoted to Professor (Research Professor) at the Department of Green Chemistry and Technology (Faculty of Bioscience Engineering, Ghent University), and he was granted tenure in 2015. His main research interests include the chemistry of small-ring azaheterocycles, with a special focus on aziridines, azetidines and $\beta$-lactams, and the synthesis of different classes of bioactive heterocyclic compounds at the SynBioC Research Group (http://www.synbioc.ugent.be). Prof. D'hooghe is the author of $>160$ publications in international journals ( $\mathrm{H}$-index 31 ) and was elected as a laureate of the DSM Science \& Technology Awards 2007, finalist of the European Young Chemist Award 2012 and recipient of the Thieme Chemistry Journal Award 2013. He organized and chaired the international Bioheterocycles 2019 conference and became a Bioheterocycles International Scientific Committee member in June 2019. 